\title{
NARRATIVAS E HISTORIAS \\ DEL MEDIO RURAL \\ PROCESOS DE INCLUSIÓN Y FORMACIÓN DOCENTE
}

María del Rosario Auces Flores

\section{Qartuppi.}

-

- Yar

rate-

ateWatill sis

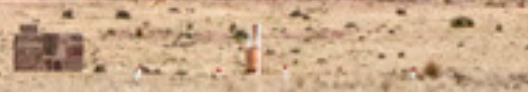

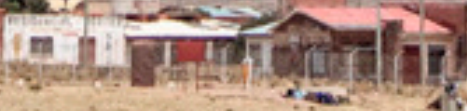

ii)

e

in 


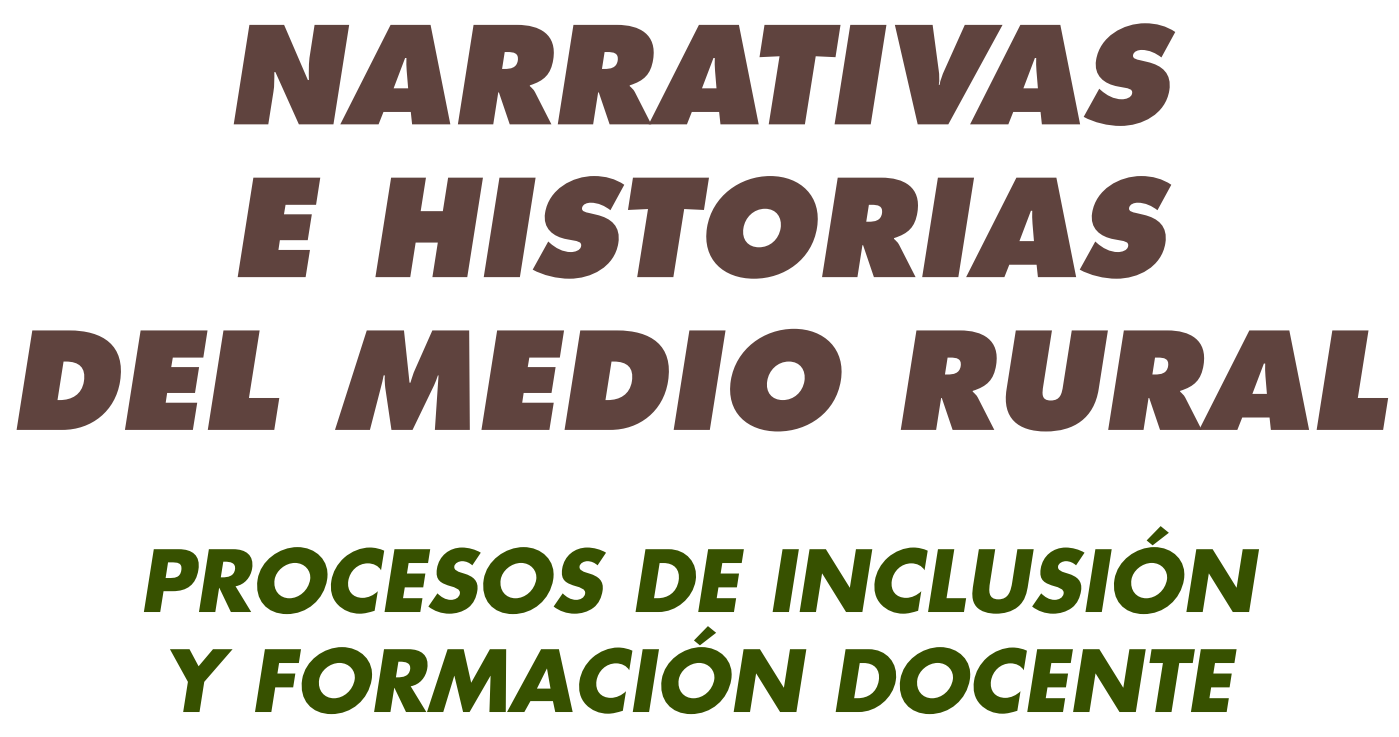

María del Rosario Auces Flores

Qartuppi 


\section{Esta obra ha sido dictaminada por:}

Dra. Jessica Gloria Rocío del Socorro Rayas Prince, Universidad Pedagógica Nacional Mtra. Norma Alicia Del Río Lugo, Universidad Autónoma Metropolitana - Xochimilco Mtra. Emilia Adame Chávez, Secretaría de Educación Pública - Quintana Roo

Narrativas e historias del medio rural

Procesos de inclusión y formación docente

lera. edición, febrero 2019

ISBN 978-607-98270-6-9

DOI 10.29410/QTP.19.03

D.R. (C) 2019. Qartuppi, S. de R.L. de C.V.

Villa Turca 17, Villas del Mediterráneo

Hermosillo, Son. 83220 México

http://www.qartuppi.com

Diseño y Edición: Qartuppi, S. de R.L. de C.V.

Fotografía de portada: León Felipe Irigoyen Morales 
La formación no consiste en mirar al "otro" diferente, sino a sí mismo, para poder intervenir en tareas de lucha, de emancipación propia y común. La educación debe crear, desde la ética y la axiología, mejores condiciones de vida y convivencia social en la búsqueda de espacios para la autorrealización y la libertad, es decir, en el reconocimiento de uno mismo a través de los otros.

GRACIAS

a las familias, docentes y directivos de las comunidades rurales por la dignidad y elocuencia de sus relatos 


\section{CONTENIDO}

6

PRÓLOGO

11

INTRODUCCIÓN

15

CAPÍTULO 1

Inclusión educativa y formación docente

Enfoques y debates

24 CAPÍTULO 2

Narrativas: Imaginarios, epifanías e identidades

$33 \quad$ CAPÍTULO 3

Lugares y sujetos del medio rural

$41 \quad$ CAPÍTULO 4

Narrativas y experiencias de inclusión educativa en el medio rural

$79 \quad$ CAPÍTULO 5

Consideracions finales

REFERENCIAS 


\section{PRÓLOGO}

Como del fondo sube una burbuja y los peces, encadenados al acuario, horadan el tedio en feroces o mansas coreografías, nosotros estamos ciegos para ver más allá del gran vidrio, del agua turbia que llamamos el tiempo.

Somos los peces de este ahora, vorazmente transformado en entonces; los prisioneros reducidos a soñar un porvenir que otros muchos soñaron y ya es nuestro presente miserable.

Fragmento de Jardín de Niños No. 19 José Emilio Pacheco

María del Rosario Auces Flores nos propone, con Narrativas e historias del medio rural, título por demás acertado de su obra, una visión que nos hace evocar la novela, El luto humano de José Revueltas (1943). Nos ofrece una realidad lacerante de nuestro país en el espejo de esa vida rural en donde tuvo puesta su mirada, su compromiso y su quehacer. A través de su obra se palpan los dolores, pesares, sufrimiento; y surge en uno la indignación, el coraje y la desesperación ante la impotencia de ver la historia repetirse $y$, peor aún, que la población más originaria de este país mantiene un lugar de olvido e indiferencia por los gobernantes, pese a los movimientos revolucionarios de 1810 y 1910.

Esa pobreza punzante en nuestro país nos muestra que no es ciertamente debida a las voluntades y decisiones en quienes cae tal condición, sino a la forma como el sistema va permitiendo la erosión de la tierra, la desertificación del campo, el agotamiento de los recursos acuíferos, y la indiferencia ante las condiciones de la población. El dominio, explotación y falta de cuidado de la naturaleza, la ausencia de responsabilidad política donde pondera la rele- 
vancia de mantenerse en los puestos de poder y/o servir a los intereses con el afán del capital, la plusvalía, el poderío y el renombre. Con todo y pese a ello, aún perviven las voces originarias; algo habla ahí mismo; ellos, los hombres y mujeres del medio rural resisten y ponen a prueba enterezas ancestrales y preservan un legado ético: la familia, la tierra, la vida y los sueños. Las voces puestas en primer plano penetran el alma. Ellos, narradores directos de sus vicisitudes, nos recuerdan las voces primigenias, los mitos fundacionales perseverantes a lo largo de las generaciones.

La autora subtitula su obra Proceso de inclusión y formación docente y consigue que terminemos por visualizar a la inclusión como un muro que invisibiliza el meollo de la cuestión educativa: el estatuto ético. ¿̨Y qué está pasando? o ¿qué es lo que no deja de pasar? Está pasando lo que siempre ha estado presente. Un pasado presente y que el verso de José Emilio Pacheco ilustra: [somos] "prisioneros reducidos a soñar un porvenir que otros muchos soñaron y ya es nuestro presente miserable" (p. 126).

Al leer este texto, uno no puede menos que enfrentarse de nueva a una historia vigente, que muestra este presente como un presente miserable, la obstinación de una condición de pobreza a la que están destinados millones de mexicanos. Por nuestros ojos transcurre, a través de las palabras de los personajes, la tumba que va cavando la modernidad: la tierra se erosiona, el agua escasea, la imposibilidad del cultivo de la tierra. La preservación de la vida se vuelve una lucha cotidiana; se emigra dejando a la familia custodiando las raíces, la sobrevivencia se da en el comercio informal, el servicio doméstico y los oficios; con el dinero que envían los braceros se reintenta suturar el tejido familiar, cultivar la tierra, erigir la casa; restablecer el orgullo, la vida y la dignidad. ¿ $Y$ la función del Estado? ¿¿ónde quedaron las promesas del bienestar enarboladas por la $\mathrm{Re}$ volución? ¿Y la Revolución no fue también una renovación de la esperanza ante el fracaso de

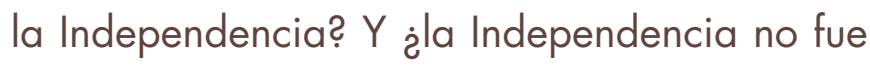
a su vez la esperanza de un porvenir? ¿Qué ha sido de todos esos sueños, esperanzas que han costado tanta sangre, violencia y muerte?

Las condiciones de vida que aquí se muestran parecieran retrotraernos al México de la conquista, como si fuese un recuento de su historia. Igualmente, volver los ojos a la historia abre la posibilidad de un porvenir diferente. La recuperación de una vida rural con sus héroes anónimos como los define De Certeau (2000), cobran carne y vida en este trabajo; conmociona y conmueve la tragicidad de la existencia, y a la vez, presenciamos la renovación, recuperación y vigencia del sentido de la familia, de la responsabilidad y de asumir un destino sin rebelión, pero de resistencia y persistencia a sus orígenes y sus valores que son el sostén de la vida, del país. La obra invita incursionar en cómo hacer de la historia una temporalidad vigente en la educación, e impedir la segmentación en modelos que ofrecen lo menos por lo más. Cuando se hace presente la laceran- 
te mancuerna pobreza y exclusión, como una consecuencia de una estructura económica neoliberal que conlleva una ausencia de ética del cuidado del otro, tal como lo muestra Redondo (2004) en la dimensión escolar, todo esto nos indica que no es el paradigma de la integración o inclusión el que resolverá el impasse educativo, sino la filosofía, la ética como fuerza que reoriente, dirija y devuelva la brújula a la dimensión social-humana desde su complejidad.

Al rebasar y mostrar el trasfondo del ámbito de la integración e inclusión educativa, Auces evita caer en la tentación de ofrecer una visión fragmentaria de la educación. Su propósito no es alcanzar la eficacia de la integración e inclusión desde la propia lógica que estos paradigmas señalan; más bien, son puestos bajo un cuestionamiento in situ y apuntan, señalan, a veces a gritos, a veces en murmullos, la búsqueda urgente de una reforma educativa global que sostenga en primer lugar una ética como base y sostén de la función educativa, por mencionar sólo el rubro de la educación.

Expresa con contundencia la urgente necesidad de iniciar desde el entramado social y cultural como clave del significado y sentido primordial educativo. Que la atención a la "discapacidad" a través de estrategias evaluativas, adecuaciones curriculares y capacitaciones se vuelven un distractor ante el fracaso del Estado que ha olvidado velar y asegurar estructuralmente las condiciones que permitan desarrollar una vida digna: empleo, salud, educación, cultura. Si bien existen las Secretarías de Estado que atienden dichos rubros, el estudio de nuestra autora muestra la realidad de esos servicios. El Estado se encuentra enajenado en las leyes de la acumulación del dinero y poder y ha perdido el estatuto ético de hacerse cargo, tomar la responsabilidad por los ciudadanos. El texto plantea con mucha fuerza la realidad rural y la lejanía de la educación, la salud, la economía, a la vez que recupera en las múltiples voces de los personajes involucrados en las prácticas educativas, su riqueza por mantener el legado, los valores, y sobre todo su tenacidad y temple ante la eterna adversidad que parece acompañarlos. Los sujetos enarbolan esperanzas, sueños y no han cedido ante el quehacer $y$ hacer por un porvenir diferente y mejor para sus hijos. Por ello, el trabajo de investigación es relevante, por recuperar a los agentes reales de las prácticas educativas, sus vaivenes, vicisitudes, conflictos, miseria y firme convicción de que a pesar de las adversidades siguen potenciando la existencia, su historia y su futuro.

El estudio permite asomarnos a la ventana del mundo rural de México y su intrincada relación con la educación, ya que no sólo articula el proceso histórico, sino que enuncia enfoques teóricos de las disciplinas sociales que le dan fuerza y contenido.

En concordancia con la formulación de una postura desde la complejidad y el ámbito multidisciplinario con énfasis en las disciplinas sociales y humanísticas, la investigación cumple en su procedimiento interno con el postulado ético. Plantean como propuesta ética velar por 
la relación humana en su condición de convivencia y responsabilidad y se constata su enunciado en el quehacer investigativo, a lo largo del desarrollo del trabajo, en su proceder y la formulación de conclusiones. Se constata el compromiso de la investigadora a lo largo de su quehacer, pensar y actuar.

Ejemplifica en las prácticas educativas el funcionamiento de una "normatividad legitima$\mathrm{da}^{\prime \prime}$, ajena a los procesos formativos y preocupada (en espejo con lo social), en instrumentar una lógica de competencia y rendimiento académico. A la vez muestra el efecto de dicha lógica en los docentes cuando uno de los alumnos destaca en algún concurso acorde a la lógica competitiva; y con ello pareciera renovarles la fe y la esperanza de su función. Retrata la organización escolar desde una "rigidez y verticalidad administrativa, ajena y cerrada en sí misma" sin sensibilidad por las condiciones ambientales y las necesidades e intereses más apremiantes de la comunidad; en cambio a través de los discursos legitimados dan cuenta de la deserción y fracaso escolar señalando la responsabilidad en las familias disfuncionales. El trabajo evidencia así, cómo algunos conceptos sólo reiteran la exclusión de aquellos grupos con mayor desventaja y, a la par, los alumnos refuerzan la discriminación a sus compañeros con nombres locales como "guásaras".

Simultáneamente, en la investigación se develan procesos formativos genuinos conducidos de nueva cuenta por esos héroes anónimos. No le resta a uno más que emocionarse y constatar cómo la autora, María del Rosario Auces, ha iniciado una veta cuya presente obra apunta como un iceberg y promete futuras indagaciones, elaboraciones y complejidades que muestren y promuevan la dinámica y potencial de transformación de los agentes.

Esperamos una tenacidad en los investigadores por producir desarrollos múltiples, diversos, plurifacéticos que ahonden con sus miradas, compromiso y nos sorprendan con material que nos permita repensar de nuevo nuestro quehacer. Por lo pronto, un gran aporte es la exploración de la realidad rural en su articulación educativa, sostener una propuesta ética y hacer de la historia una temporalidad vital de la educación para su transformación. Quizá esa sea nuestra esperanza, que tenemos la historia, que la podemos recuperar y quizá al tomarla en serio, no como algo que pasó, sino lo que nos pasó, que no pasó del todo, que sigue vivo, hará que nos mantengamos alerta y evitar mantenernos -parafraseando a José Emilio Pacheco en el verso que dio inicio a este prólogo-, ciegos y prisioneros de un porvenir de discursos de integración e inclusión, de bienestar, igualdad y equidad y trascender estas prometedoras palabras y más que atender a su significado, tendríamos que apuntar a lo que esconden, nublan, enceguecen, velan en nuestro presente miserable y que hace que mantengamos los prejuicios de exclusión y discriminación, que repitamos hoy un pasado que enunció, pronunció y nos proyectó a un futuro que ya es este presente, en donde mantene- 
mos, reproducimos los signos, significados, actos y prácticas de separación, discriminación, exclusión o indiferencia entre los hombres.

En Narrativas e historias del medio rural, sin duda, las voces inolvidables de niñas, niños, madres y padres de familia, entre tantas voces, nos descubren lo disimulado y obscuro de las palabras de los buenos discursos y buenas intenciones $y$, al mismo tiempo, - a veces como la intensidad de la luz de un relámpago y a veces bajo la tenue luz de una vela, o de una luciérnaga-, nos muestran quiénes, cómo y en dónde se encuentran los guardianes de la convivencia humana, de la preservación y custodia del ser humano, de la preocupación y resguardo de la existencia del otro en su diferencia y sostener la singularidad de su y mi "ser" otro diferente y resistir a la tentación de normalizar-lo o normalizar-me, integrarme e incluirme a costa de perder mi singularidad, mi otredad, mi diferencia.

Mantener una vigilancia, epistémica y ética de nuestros discursos y nuestras prácticas es un constante pronunciamiento en este trabajo; de no hacerlo, mantendremos en esta agua turbia que llamamos tiempo y sin que nos demos cuenta, un discurso o saber cómo la inclusión o integración que sólo promete como evangelización la equidad, el saber y el bien de nuestros semejantes a condición de dar la espalda a la realidad. Una postura ética implica atender la imaginación radical de los sujetos, es una invitación, una promesa, un ofrecimiento, una apuesta y una propuesta de la autora como potencial de transformación.

A través de la imaginación radical, de acuerdo con la autora, todo sujeto puede: "desarrollar la capacidad de tomar decisiones y elegir el sentido de su existencia, orientándose por las condiciones sociales externas". De esta manera, las epifanías o momentos críticos parecen "activar" una gran capacidad de ajuste y fortaleza no sólo física sino emocional frente a las adversidades, capacidad de resistencia desarrollada precisamente por estas situaciones extremas. $Y$ yo agregaría que siempre y cuando alguien, uno, unos cuantos y para este caso, un docente, un director, un padre de familia mantenga la ley primordial de la lealtad al prójimo, mantendremos la posibilidad, así las situaciones extremas parezcan rebasarnos, al responsabilizarnos del otro y por el otro, que implica también una responsabilidad y lealtad por uno mismo, mantendremos la ética de la fraternidad, que no la vida, la vida se cuida por sí misma, en tanto que los humanos, si no cuidamos del otro estaremos condenados a la desaparición. La obra que el lector tiene en sus manos nos muestra cómo, a pesar de que vemos los efectos del dominio de una lógica de devastación, algunos docentes, padres, directores, hermanos, mantienen la lealtad por la ética de la fraternidad que augura siempre la posibilidad de un porvenir diferente.

\section{Dra. Zardel Jacobo}




\section{INTRODUCCIÓN}

Narrativas e historias del medio rural. Procesos de inclusión y formación docente es producto de una investigación desarrollada durante el período 2004-2009. Al cabo de este tiempo, se considera que el tema que se aborda sobre la inclusión educativa y su repercusión en el campo de la formación docente es un debate vigente.

Lo anterior se explica a través de la perspectiva de los Derechos Humanos, pues si bien, hoy en día las políticas pretenden incidir en la reivindicación de los grupos que se encuentran en situaciones de mayor desventaja, se discuten al mismo tiempo las culturas y las prácticas que requieren ser transformadas para su legitimización. Al respecto, Guglielmino (2009) hace una diferenciación entre lo legal y lo legítimo, al asumir que mientras el primero se inscribe en el marco del derecho, el segundo se ubica en lo ético-axiológico.

Hablar sobre la inclusión educativa y la formación docente implica, por tanto, reconocer enfoques, contextos, procesos, experiencias y sujetos. La distancia que existe entre las políticas educativas, las culturas y las prácticas sobre los procesos de inclusión educativa han tratado de ser abordadas a la luz de distintas teorías sobre lo que significa "ser diferente" y "ser docente", aunado a la consecuente necesidad de describir "el hacer profesional" desde esta perspectiva.

Como señala Skliar (2008), entre el establecimiento de leyes y su inscripción en nuestras subjetividades, algo sucede en la adversidad cotidiana que permite reconocer las diferencias 
como algo que da sustento, fuerza y vitalidad a la condición humana, es decir, a la esencia de la razón educativa. Es entonces cuando lo legal podría ser aceptado como válido, instituyendo de esta forma su legitimidad y el compromiso moral de asumir la responsabilidad de educar "a los otros", cualquier "otro" y reconocer nuestra condición humana posicionándonos en un encuentro de igualdad y justicia social.

Desde esta óptica, se recupera la narrativa de aquellos sujetos que han vivido la experiencia del proceso de inclusión educativa en el medio rural a través de sus relatos de vida, entendiendo por sujetos no sólo a los alumnos, sino a las familias, a la comunidad, a los docentes, a los directivos y a las autoridades que comparten dicha experiencia. Se considera que de esta manera puede evidenciarse la forma como se concretizan o dejan de hacerlo, los principios y postulados que, desde la retórica, tejen los discursos políticos y sociales.

La mayoría de los estudios que analizan el proceso de inclusión educativa y su relación con el campo de la formación docente se centran en ambientes urbanos escolarizados, en el aula y en las formas de trabajo e interacción entre alumnos y maestros. Focalizar el presente trabajo hacia el medio rural abrió nuevos retos y perspectivas, al considerar el concepto que puede tener "lo rural", dada la complejidad que se observa en las comunidades por la mezcla de elementos naturales, geográficos, económicos, políticos, sociales y/o culturales que se yuxtaponen y confunden en tiempos y espacios.
Las preguntas centrales fueron: ¿Cómo ha sido el proceso de inclusión educativa en el medio rural? y żqué implicaciones tiene para el campo de la formación docente? Fue así como se desarrolló una investigación en dos líneas: documental y de campo. La primera permitió identificar los enfoques que subyacen en torno a la forma de abordar y entender la relación que existe entre la inclusión educativa y el campo de la formación docente. La segunda favoreció el acercamiento a la realidad social desde la narrativa de los sujetos involucrados: autoridades, directivos, docentes, padres de familia y alumnos. La finalidad fue indagar qué pasaba en esas escuelas y en esas comunidades, cómo respondían los docentes al proceso de inclusión educativa, qué pensaban los padres de familia y cómo lo vivían los alumnos, como sujetos que actúan, sienten, piensan, toman decisiones y resuelven problemas, como parte de su vida personal, familiar, escolar y social.

En ese sentido, el enfoque biográfico narrativo (Bolívar, Domingo y Fernández, 2001) ofreció un contacto distinto entre investigadores e investigados, al establecer una relación horizontal y de reconocimiento mutuo como constructores de la realidad y coautores de su registro. Los espacios de escucha fueron el patio de la escuela, el aula de apoyo, la dirección, los salones; pero también lo fueron las casas de los alumnos sentados en la mesa, alrededor de un fogón, bajo la sombra de un árbol en el solar, e incluso la sala de neonatos en el hospital infantil. 
Así, en este libro se presentan tres estudios de caso de tres comunidades del Municipio de Mexquitic de Carmona, San Luis Potosí, México. La investigación se desarrolló durante el período de 2004 a 2009 y el trabajo de campo se desarrolló durante el ciclo escolar 2005 2006. La metodología fue de corte etnográfico haciendo una visita semanal a cada comunidad para lo cual se llevó un diario de registro; de igual manera, se realizaron entrevistas abiertas a los participantes. Se presentan, por tanto, datos estadísticos encontrados durante la etapa de estudio, así como la actualización de los que se consideran más relevantes para mostrar cómo ha habido una tendencia de incremento relativo en todos los indicadores: índices de población, escolaridad y servicios, en contraste con un indicador persistente y significativo de pobreza (moderada y extrema).

En el primer capítulo se analiza la relación dialéctica que existe entre el proceso de inclusión educativa y el campo de la formación docente, es decir, como ámbitos estrechamente dependientes y determinantes entre sí, pero cuyos enfoques pueden ser contradictorios $y$, por tanto, determinar e incidir en su desarrollo o retroceso.

En el segundo capítulo se aborda los principios teóricos y metodológicos que sustentan este estudio a partir del procedimiento de "relatos cruzados" y polifónicos derivados de la implementación del método biográfico (Ferraroti, 1993 y Lewis, 1961, citados en Bolívar et al., 2001) desde tres ejes de análisis: imagi- narios (Castoriadis, 2002); epifanías (Denzin y Lincoln, 1989); e identidades (Aguado y Portal, 1992).

En el tercer capítulo se describen los lugares y sujetos de estudio. Desde esta perspectiva, la definición de "lo rural" cobra relevancia ante una realidad social compleja y múltiple. Se trata de justificar la importancia que tiene contextualizar la problemática desde lo rural en un mundo en el que confluyen de forma sincrónica y diacrónica sucesos y lugares heterogéneos donde el pasado y el futuro componen el presente caracterizado por grandes contrastes físicos, culturales y educativos.

En el capítulo cuatro se presentan los tres casos del proceso de inclusión educativa en el medio rural elaborados a través de un análisis comparativo entre lo que enuncia la evaluación psicopedagógica de alumnos que pertenecen al programa de integración educativa, su maestra de grupo regular, el equipo de apoyo, los padres de familia $y / 0$ directivos de escuela, como sujetos que participan en este proceso.

El primer caso: "Una verdad manifiesta" es de la comunidad de Guadalupe Victoria. El caso permite reconocer cómo la comunidad y la escuela están pasando por un proceso que va de la "no aceptación de las diferencias" (en el cual subyacen significaciones sociales acerca de las diferencias individuales como sinónimo de "incapacidad") hacia "el reconocimiento" (no siempre consciente) de las capacidades potenciales que posee todo individuo. Un alumno de esta escuela que cursa el tercer grado de pri- 
maria ha ido demostrando paulatinamente, a la familia, a la escuela y a la comunidad en general que la capacidad de aprender es independiente de las características físicas de los sujetos.

El segundo caso: "El conflicto no resuelto", se desarrolla en Corte Primero, una de las comunidades más grandes en territorio y población del municipio de Mexquitic de Carmona. En este caso se observa el rechazo de la comunidad y de la escuela hacia algunos alumnos de familias que pertenecen a los sectores más desfavorecidos económica y culturalmente. A una de estas familias pertenece una alumna de 12 años que ha sido repetidora del primero y segundo grado al no lograr adquirir la lectoescritura. El estudio muestra cómo responde la escuela, la familia y la niña ante esta situación de exclusión social y escolar.

El tercer y último caso: "Construyendo caminos y alargando distancias" es de la comunidad de Derramaderos, la cual se encuentra aproximadamente a 15 kilómetros de la cabecera municipal. En éste, se da cuenta de la dificultad que existe en el medio rural sobre las distancias y los tiempos a través de la situación que viven dos hermanos, un niño de 10 años $y$ una niña de 7 años, ante la decisión de sus padres de cambiarlos de la primaria de su comunidad a la escuela integradora de la cabecera municipal por considerar que es ahí donde esta última puede recibir la atención que necesita, de acuerdo a sus características y posibilidades.

El quinto capítulo presenta las reflexiones y consideraciones en torno al proceso de la inclusión educativa y la formación docente en el medio rural. La intención de poder reconstruir este proceso como experiencia vivida y narrada por los sujetos permitió reconocer la narrativa y el método biográfico como formas de aprehender la realidad social y educativa desde un encuentro humano entre investigador e investigados. La contextualización histórico-social como experiencia de vida buscó una comprensión más profunda sobre lo que significa "educar por y para las diferencias".

Abordar la inclusión educativa y el campo de la formación docente desde la intersubjetividad que posee todo proceso social y educativo permite confirmar cómo el estudio de la condición humana y los procesos de identidad que se construyen y son construidos a partir de y en relación con los otros, dan lugar al cambio en las formas de ser y hacer la docencia y ubican a la escuela como espacio de exclusión y desencuentro o bien, como un lugar propicio para el encuentro y la realización propia y común. 


\section{CAPÍtULO 1}

\section{Inclusión educativa y formación docente. Enfoques y debates}

La inclusión educativa como proceso histórico, social, político, económico y cultural ha sido abordada desde distintos enfoques teórico-conceptuales. Un importante referente de análisis para entender las fuertes implicaciones que en lo social y educativo conlleva, especialmente en el campo de la formación docente, es la forma como se explican y conciben las diferencias individuales.

En este capítulo se abordan los paradigmas histórico sociales que han estudiado el tema de la inclusión educativa de niños, jóvenes y adultos con discapacidad en los marcos internacional, nacional y local, así como las consecuencias que éstos tienen para el campo de la formación docente. De esta forma, hay planteamientos generales como los de la Organización de las Naciones Unidas para la Educación, la
Ciencia y la Cultura (UNESCO, 2005) que señala que la inclusión educativa es un proceso que trata de dar respuesta a la diversidad de necesidades de todos los estudiantes a través de una mayor participación en el aprendizaje, las culturas y las comunidades, así como la reducción de la exclusión dentro y desde la educación (p. 13). No obstante, las formas de lograrlo serán con relación a las condiciones específicas de cada contexto, así como de la participación, el consenso y puesta en común de los acuerdos y las acciones que cada comunidad considere más pertinente. En ese sentido, se establece que:

La inclusión educativa es lo que cada comunidad define y concreta en cada caso y cada día como tal, en función de su contexto, de su historia, de su 
cultura escolar y de sus múltiples condicionantes (económicos, políticos, culturales, etc.) y cuando ello es, además, el resultado de un genuino proceso de deliberación democrática, a través del diálogo igualitario de quienes forman cada comunidad educativa comprometida. (Elboj, Puigdellívol, Soler y Valls, 2002; Nilhom, 2006; citados en Echeita, 2009, p. 29)

De esta forma, los procesos de inclusión no son homogéneos, es decir, son múltiples, diversos e incluso contradictorios, en tanto se desarrollan de acuerdo a las condiciones específicas de cada comunidad, así como a los diferentes enfoques que subyacen desde la perspectiva de sus integrantes. No obstante, la inclusión educativa aporta los principios bajo los cuales deben orientarse y coordinarse las acciones desde la participación, la colaboración y la puesta en común de todos los involucrados.

\section{Paradigmas en torno a la discapacidad}

Si bien, se han definido paradigmas que abordan el concepto de "discapacidad" que inciden en la toma de decisiones y el diseño de políticas y acciones, hoy es necesario reconocer la complejidad que implica dadas las condiciones geográficas, demográficas, políticas, históricas, sociales y económicas de los distintos países en los que se desarrolla.

A un siglo de distancia, Villa (2009) destaca que las personas con discapacidad de forma paulatina han pasado de "la oscuridad y el ocultamiento" a "la visibilidad y el reconocimiento" como sujetos de derecho. El proceso como tal no ha sido sencillo ni lineal. Los paradigmas que abordan este campo de estudio se traslapan, se contraponen, se confunden e incluso se relacionan entre sí.

Al realizar un estado del arte sobre el tema de la inclusión, Slee (1998, citado en Mitchell, 2004 , p. 2) identifica cinco paradigmas:

1. Esencialista o modelo médico y psicológico, donde la discapacidad se considera desde el déficit.

2. De construcción sociopolítica, la discapacidad como constructo social y político.

3. Materialista, que concibe la discapacidad como una forma de exclusión creada por el sistema económico.

4. Postmodernista, muestra las experiencias de personas con discapacidad como discontinuidades y rupturas.

5. Movimientos, cambios sociales y empoderamiento de las personas con discapacidad.

El enfoque sociohistórico que caracteriza a este último modelo reconoce las ideologías y leyes que han justificado actos de eugenesia y discriminación como la esterilización forzada - la negación del derecho al matrimonio y a la paternidad. Estas medidas se basan en estereotipos sobre la discapacidad al concebirse como sujetos que viven una tragedia personal, incapaces de tomar decisiones por sí mismos, con un gran impacto de las leyes discrimina- 
torias resultantes de los valores y prejuicios de la sociedad (Oliver, citado en Barton, 2008).

Por su parte, Pfeiffer (citado en Barton, 2008) señala que:

Las leyes estatales que discriminen a las personas con discapacidad deben declararse nulas, $y$ las decisiones judiciales anteriores que permitieron tal discriminación deben revocarse. También deben revisarse las regulaciones estatales y federales mediante las que se implementan las leyes... La idea que debe desarrollarse es que las personas con discapacidad pueden ocuparse de sus propios asuntos, de ser ciudadanos responsables y contribuyentes, de ser amantes, contraer matrimonio, ser padres y formar una familia, como cualquier individuo. (p. 13)

Se considera que lo anterior será posible en la medida que la educación contribuya a eliminar las concepciones y estereotipos que hasta ahora han existido y las instituciones puedan ofrecer una atención diversificada según las necesidades y las características de los niños y los jóvenes acorde a los contextos y a las demandas sociales.

A través de la consulta a expertos de países como Nueva Zelanda, Estados Unidos, Inglaterra y Singapur, Barton (2008) plantean cómo dos campos, la educación especial y la educación inclusiva, han evolucionado filosófica y técnicamente en los últimos 25 o 30 años.

El estado contemporáneo del arte en investigaciones sobre la educación de los estu- diantes con necesidades educativas especiales se centra en cuestiones como: ¿ Cuáles son las metas educativas con ellos? ¿¿Deberían ser categorizados o no? ¿Cuál es la intersección entre discapacidad, etnicidad, género y clase? ¿ ¿ónde deberían educarse, en espacios especializados o escuelas regulares? ¿Qué conocimientos constituyen la educación especial y la educación inclusiva? ¿Cuál es el impacto de las reformas educativas generales sobre su educación? ¿Cómo debería ser financiada su educación y cómo tales decisiones se toman con relación a los principios de igualdad y equidad? ¿ Cuál es el currículum más apropiado? ¿Cómo debería ser su evaluación? ¿Cuáles son las estrategias de enseñanza más efectivas? ¿Cuál es el rol de los padres, por ejemplo, en la toma de decisiones para la ubicación de sus hijos con necesidades educativas especiales? ¿Cómo debería capacitarse o formarse a sus maestros y asociaciones de profesionales? ¿Cuál es el papel de la investigación en la toma de decisiones?

Un tema central versa sobre la identidad de los estudiantes. Las perspectivas que definen la discapacidad desde el modelo del déficit hasta el modelo de reivindicación y empoderamiento de las personas como sujetos de derecho; este último se opone a representaciones sociales que pueden ir desde actitudes de rechazo, lástima y caridad, para considerarlos sujetos como cualquier otro, diferente, complejo y completo, con capacidad para transformar la realidad social. Algunos críticos de esta postura socio política, de acuerdo a Christensen (1996, 
citado en Mitchell, 2004, p. 8) son Heward, 2003; Kauffman 1999; Kavale y Mostert, 2003; y Sasso, 2001.

Otros temas centrales se refieren, por ejemplo, al concepto de "normalización" establecido por Nirje en 1976, el cual procuraba "considerar que las personas con discapacidad intelectual llevaran una vida tan normal como fuera posible"; término que promovió la consideración de esta posibilidad a la vez que causó gran confusión y desacuerdo al estar anclado en una dualidad "normalidad/anormalidad" y el ajuste a lo que se consideraba "normal". Ahora se ha tratado de reemplazar este término por el de: "valorización del rol social" de las personas con discapacidad (Mitchell, 2004, pp. 9-10).

El financiamiento, es otro tema importante, ya que los alumnos con necesidades educativas especiales reciben 2.3 veces más servicios que los estudiantes en general y esto lleva a considerar si es sostenible y de qué manera comprobar su efectividad (Parrish, 2000 citado en Mitchell, 2004, p. 12).

Otro foco de atención es el concepto mismo de educación inclusiva, su origen, racionalización, implementación, evidencias de investigación y críticas, también es importante considerar la evaluación y estrategias de enseñanza, los materiales diversificados, el personal y el papel de la familia. Finalmente, cobran relevancia las tareas de investigación sobre intervenciones efectivas con una orientación inclusiva y la distancia o brecha que existe entre ésta y la práctica.
En México, la investigación está permitiendo adoptar una postura que contribuya a una concepción sociopolítica sobre la discapacidad, al cambio social y al empoderamiento de las personas en situación de exclusión por condiciones de vulnerabilidad desde el paradigma de los derechos humanos (Del Río, 2009; López, Méndez y Mendoza, 2014; Ramos, Méndez y Mendoza, 2009; Jacobo, 2012).

El enfoque crítico social plantea que la adopción de terminologías reflejan la confusión que existe entre un enfoque médico, interaccionista y educativo y pone en el centro de discusión que, al superar un modelo dual de clasificación de las diferencias ("con" y " $\sin$ "), la concepción del sujeto no puede ser reducida sólo a un aspecto parcial de su individualidad, sino que debe considerarse un sujeto "total" (Pérez de Lara, 1998), que pertenece a un grupo y que está inmerso en un contexto específico que define sus interacciones con la naturaleza y sus relaciones con la sociedad.

"La estigmatización" es un proceso dual de roles y relaciones entre los considerados "normales" hacia aquellos sujetos considerados socialmente "inferiores y peligrosos" que, en distintas fases de la vida, pueden asumirse en uno $u$ otro sentido; por lo que funciona como medio de control formal en un sistema competitivo y de selección social (Goffman, 2003).

La gran familia indefinida y confusa de los anormales, el temor a los cuales asediará el final del siglo XIX, no marca simplemente una fase de 
incertidumbre o un episodio poco afortunado en la historia de la psicopatología; se formó en correlación con todo un conjunto de instituciones de control, toda una serie de mecanismos de vigilancia y distribución; y cuando haya sido casi enteramente englobada por la categoría de la degeneración, dará lugar a elaboraciones teóricas irrisorias, pero de efectos duramente reales. (Foucault, 2006, p. 297)

Desde la genealogía de Foucault, es importante señalar, a través de la relación poder-saber, cómo se han ido transformando las concepciones acerca de las diferencias individuales, de tal manera que conceptos como la locura, lo anormal y la no razón puedan ser reconocidas como constructos histórico-sociales que actualmente requieren de una revisión teórica más profunda. La dialéctica de la razón engendra en sí misma la sinrazón que la constituye. La normalidad es la negación de su opuesto y de su existencia en sí misma.

De acuerdo a Filidoro (2003), "La diferencia es una construcción social, el discurso engendra la diferencia, los niños no educables, los niños especiales, son la creación de un discurso social escolar puesto en circulación en el inicio de la modernidad" (p. 58).

A lo largo de la historia se ha ido forjando en la cultura popular y en la propia sociedad un concepto de las personas excepcionales como algo negativo, como una enfermedad que afecta a la humanidad y que hay que aniquilar, denominándola "cultura negra" apoyada en algunos casos de la eugenesia (Barton y Torres,
1998). Esta visión social y médica, apoyada por la psicología, sobre las personas excepcionales ha contribuido a legitimar instrumentos $y$ remedios exterminadores inaceptables desde el punto de vista humano.

La cultura de la diversidad podría considerarse en esta línea como un intento de reducir o eliminar la dualidad normal/anormal o la desviación de una respecto a la otra. Pero, la desviación no se halla en el sujeto en sí sino fuera de él, es decir, como construcción histórica y social. Por tanto:

[...] la Cultura de la Diversidad no es el proceso para integrar personas en la escuela, sino la lucha contra cualquier manifestación de segregación ya sea por razón étnica, de hándicap, de género, religión, etc. Lo que está en juego no es que las personas con hándicap aprendan más o menos estando en la escuela con el resto de las niñas y de los niños, sino que la escuela pública sea una escuela de todos y para todos, pero con todos. Es decir, una escuela sin exclusiones, en la que la comprensión de la diversidad y de la diferencia humana en las aulas sea un elemento de valor para mejorar la cultura escolar y ello ha de suponer para el profesorado comprometido, enfrentarse con retos muy importantes, tales como: la lucha contra las desigualdades, la integración de las minorías en la vida escolar, la educación frente al racismo y la xenofobia, la convivencia y el respeto entre el género y las religiones, etcétera. (López y Guerrero, 1993, p. 25) 
Una postura crítica abarca complejos problemas sobre la discapacidad desde una dimensión política: cómo se percibe, quién la percibe y con qué consecuencias para las partes implicadas; la naturaleza y el impacto de las teorías ideológicas de la normalidad; el proceso de formación de la identidad y la interpretación social de la necesidad; la política de la participación, la lucha por la ciudadanía y por un futuro diferente y el movimiento de la discapacidad como un nuevo movimiento social para el cambio de la sociedad contemporánea (Barton y Torres, 1998).

Una significativa distinción entre diversidad y diferencia es que la primera es utilizada en los discursos neoliberales con una marcada tendencia a negar las diferencias -la indiferencia de la diferencia- en tanto construcciones sociales e históricas, naturalizando y silenciando los profundos desencuentros, conflictos $y$ problemas que surgen entre los grupos sociales a partir del orden social vigente. A esta negación del conflicto le denomina un "bálsamo tranquilizante" que busca legitimar los intereses de los grupos hegemónicos y en el que la escuela no está ajena a estos procesos. Desde un enfoque crítico, en los actuales discursos, lo que se naturaliza y oculta -bajo el respeto y la tolerancia- son las relaciones asimétricas de poder que organizan las diferencias y producen las desigualdades socioculturales. La diferencia debe ser problematizada desde las condiciones políticas e históricas que la producen, como un núcleo explicativo básico para que, a partir de su reconocimiento activo, logren pro- ceso de emancipación aquellos sujetos que han sido discriminados. Para que, de la alteridad negada, sea capaz de vivir en una "alteridad transformadora" (Homii Baba, 1994 citado en Guglielmino, Valente y Mendes, 2003, p. 66).

Finalmente, hay planteamientos acerca de una nueva revolución, conocida como Regular Education Initiative (REI) y representa un número de propuestas para conseguir que el espíritu de la inclusión para estudiantes "con discapacidades" extienda sus derechos a todos los estudiantes. De ahí que el planteamiento de la inclusión implique siempre una reestructuración que afecta desde un planteamiento político que dé respuesta a las demandas de la igualdad de oportunidades, reconociendo el derecho a ser diferente, hasta el desarrollo de un modelo basado sobre una pedagogía capaz de incluir las diferencias (Strick, 1991 citado en García, 2001).

\section{Implicaciones de los paradigmas en el campo de la formación docente}

Desde el modelo de la escuela moderna, ha sido cada vez más criticado este cuestionamiento a la sociedad misma con relación a las formas de definir la discapacidad y cualquier tipo de diferencia existente entre los grupos que la conforman, así como a los sistemas educativos, por los fines contradictorios que persigue: democracia e igualdad social frente a un sistema económico competitivo y jerarquizado.

Los análisis realizados desde diferentes disciplinas han ido perfilando los anhelos y deseos de una sociedad democrática, que 
considera a todos los seres humanos independientemente de sus condiciones biológica, física, económica o social, si se le ofrecen las condiciones políticas y sociales necesarias, pero para ello, deben cambiar las significaciones sociales y culturales que promuevan y validen su desarrollo. La diversidad se está manifestando como una característica inherente a la condición humana en su totalidad y a las posibilidades de un aprendizaje diferenciado en general. Los conceptos de "discapacidad" y, según el análisis precedido, de "necesidades educativas especiales con y sin discapacidad" cada vez son más cuestionados y menos aceptados dado que, como constructos sociales, no responden a este principio.

Diversidad significa variedad, diferencia. El concepto se empleó en la biología en un inicio para caracterizar a los seres vivos en general. El término fue trasladado al campo de lo social al reconocer su presencia en la cultura. Diversidad de ideas, diversidad histórica y diversidad política que, al igual que la diversidad biológica, es una condición y una cualidad humana e inherente que la enriquece y la hace sorprendente.

la promoción de la diversidad y el pluralismo debe fundarse en la mínima satisfacción de las necesidades básicas, un mínimo que descarta la exclusión y la marginación; en un mínimo de recursos y capacidades (desde no pasar hambre, hasta gozar de salud, educación y vivienda adecuadas). (Pérez de Cuéllar, 1997, p. 265)
Diversidad e igualdad cobran vida en los acuerdos establecidos en el ámbito mundial por las distintas organizaciones políticas y sociales (Organización de las Naciones Unidas [ONU], UNESCO, Organización Mundial de la Salud [OMS], etc.) que buscan el desarrollo de la humanidad en lo general y se circunscriben al establecimiento de una serie de principios y acciones en materia de salud, educación y recreación. Su repercusión incide de manera directa en el ámbito nacional, a través de la generación de políticas y estrategias: Planes $\mathrm{Na}$ cionales de Desarrollo y Programas Emergentes para justificar y poner en marcha una serie de acciones que buscan lograr los propósitos encomendados.

Con respecto a lo educativo, se señala que es de vital importancia adoptar una "visión holística" de la cultura. Debe apreciarse la diversidad cultural en cuanto a valores y formas de expresión, basado en el reconocimiento y el respeto a las diferencias. Esta condición permite derivar el concepto de "diversificar", es decir, de diferenciar para adaptar a distintos usos y funciones. En ese sentido, la diversidad social y cultural implica diversificar la práctica educativa. Este principio pedagógico es la base de la filosofía de la inclusión educativa.

El principio que enuncia: "El significado práctico de la doctrina de la igualdad humana no consiste en que las personas deban ser tratadas como si tuviesen iguales capacidades, sino como si tuviesen el mismo valor" (Pérez de Cuellar, 1997, p. 81), actualmente puede 
traducirse en el cuestionamiento abierto a las significaciones sociales transmitidas acerca del poder y el ser humano a través de las condiciones sociales, culturales y económicas en las que se justifican y se reproducen.

Ahora bien, desde esta perspectiva social de formación docente, un profesional competente en la educación para la diversidad exige un proceso formativo desde un enfoque crítico, es decir, capaz de participar en colaboración con otros en el cuestionamiento y reflexión de la práctica educativa para establecer los fines de igualdad, liberación y emancipación a través de la acción común (Contreras, 1997).

De allí la importancia que merece, a nuestro juicio, que los docentes puedan reflexionar colectivamente sobre el conjunto de sus saberes implícitos (de los que la historia es sólo un componente) puestos en juego en la práctica escolar: indagando acerca de lo que Bordieu denomina "habitus" o historia incorporada, sistema de esquemas adquiridos que se traducen en categorías de percepción y apreciación o principios que clasifican, y al mismo tiempo ordenan la acción; buceando, al decir de Giroux, en sus propias historias, fijándose en la "historia sedimentada" que van forjando a su alrededor, y aprendiendo cómo el propio capital cultural representa una interrelación dialéctica entre la experiencia y la historia. (Alliaud y Duschatzky, 1998, p. 11)

El tipo de profesional de la educación que exige la sociedad actual es: "estar compro- metido con los intereses de las mayorías, sensibilizado ante la problemática social, consciente del significado y alcance de la tarea que, como educador, puede ejercer en pro de las transformaciones sociales" (Ribeiro, 1992, p. 49).

Algunos aportes sobre los conceptos de diversidad e igualdad se relacionan directamente con lo que Davini (1989) titula: Formación de profesores y transición democrática: continuidad y transformaciones. O bien, lo que se entiende por "visión multicultural de la educación". Así como con el enfoque crítico-reflexivo que busca la profesionalización docente a partir de la recuperación de sus raíces, de su propia historia, es decir, de la apropiación y concientización del pasado colectivo como medio para superar un saber incorporado y no cuestionado, reconociendo al mismo tiempo, el carácter arbitrario del modelo que se presenta como natural para poder ser modificado.

Preparar al docente significa construir espacios de reflexión, análisis e investigación en su campo para que "trascienda los límites en los que se encuentra, en ocasiones por sometimiento, otras por apatía e incluso por ignorancia, pero no esperar las condiciones óptimas para comenzar la tarea" (Ribeiro, 1992, p. 7). Los modelos alternativos de formación docente en y para la diversidad rompen con este sistema paralelo de formación técnica y especializada, y se sustentan en un desarrollo profesional general con una formación común en su etapa inicial y especializada en un segundo momento; o bien, alternada durante la etapa de formación permanente. 
La formación significa pues una relación interactiva entre teoría y práctica por lo que la profesionalización del profesorado en general y de otros profesionales de la educación se torna permanente. La propuesta es que, tanto los docentes de educación regular (ER) como de educación especial (EE) deben tener un currículum de formación inicial común, básico o compartido, así como una preparación terminal y continua alternativa, diferenciada o específica.

El enfoque crítico social exige un cambio ideológico y normativo en el campo de la formación docente, a través de una actitud reflexiva y de compromiso social, que atienda a los principios de reconocimiento de la diversidad como valor, diseño curricular y trabajo colaborativo (Alegre de la Rosa, 2000).

En suma, la orientación en el campo de la formación docente ha sido, de una manera generalizada, incrementar la cantidad de los servicios y mejorar la calidad en los procesos de capacitación y actualización docente. Se identifica una mezcla de posturas positivista e interaccionista para la atención de los sujetos de la integración y no se encuentra una alternativa oficial con una visión crítica de formación docente. Es así como se observa "un vacío" en este campo.

Desde este análisis, se comparte la idea de que la educación y el campo de la formación docente deben romper con procesos de formación paralela que se basan en clasificaciones dicotómicas en cuanto a la caracterización de los individuos para responder a la diversidad biopsicosocial como condición natural humana.
Se aboga por programas de formación común que respondan a la multiplicidad de condiciones y aspectos presentes en todo grupo social y que se manifiestan en los procesos educativos en general con una perspectiva social y emancipatoria.

Una de las más grandes implicaciones de la inclusión educativa en el campo de la formación docente se manifiesta en dos aspectos: los principios curriculares y la profesionalidad del magisterio que establecen la necesidad de una formación común basada en los principios de la diversidad, esto es, que todos los profesionales de la educación asuman el compromiso ético y la responsabilidad social de atender a la diversidad de los alumnos, considerando la flexibilidad en el currículum y la búsqueda del acceso a la educación en igualdad de derechos.

Se considera que, con base en el análisis desarrollado en este capítulo, la formación docente requiere, muy por el contrario, a lo que establecen las políticas oficiales de expansión y consolidación de los servicios, una formación desde disciplinas sociales como la antropología, la sociología y la historia que contribuyan a formar una conciencia ético política de las diferencias en todos aquellos profesionales que participan en este proceso. Las tareas de selección, diagnóstico e intervención psicopedagógica darían paso a estudios sociodemográficos y culturales de los contextos para el diseño de acciones de intervención social y política con el fin de resolver problemas desde un enfoque participativo y comunitario. 


\section{CAPÍtULO 2}

\section{Narrativas: Imaginarios, epifanías e identidades}

\section{Narrativa y método biográfico}

Bolívar, Segovia y Fernández (2001) señalan que, dentro de la investigación cualitativa, la investigación biográfico-narrativa puede ser comprendida como investigación experiencial, esto es, como una particular reconstrucción de la experiencia (del plano de la acción al sintagmático del lenguaje) por la que -mediante un proceso reflexivo- se da significado a lo sucedido o vivido.

La investigación biográfico-narrativa no se considera, por lo tanto, sólo como un método sino como un enfoque propio que se orienta hacia una perspectiva interpretativa de los fenómenos sociales. El texto cobra su valor y significado por la autointerpretación que los sujetos relatan en primera persona; por ello, se caracteriza como unidad comunicativa del lenguaje con una coherencia de una secuencia de signos, que tiene un sentido completo o cierre, y una intencionalidad (Bolívar et al., 2001).

Eugenio Trías, en su obra Ética y condición humana utiliza la noción de sujeto narrativo como:

alguien que se expresa y manifiesta en aquel conjunto de relatos y narraciones a través de las cuales se constituye en sujeto. "Sujetos de narraciones" y sujetos "referidos" por narraciones que otros cuentan de nosotros. Nuestras vidas son relatos... Y en ese ser sujetos de narración y relatos se cifra también nuestra propia dignidad. (citado en Bolívar et al., 2001, p. 15) 
La tarea investigativa consiste en solicitar "contar historias" acerca de los hechos o acciones y, a partir de su análisis y comprensión conjunto, "interpretar" y construir nuevas historias/relatos que den cuenta de los procesos educativos.

La investigación biográfico-narrativa se emplea como una categoría amplia que -ostensivamente- incluye un extenso conjunto de modos de obtener y analizar relatos referidos, como dice Gusdord, al territorio de las escrituras del yo: historias de vida, historia oral, escritos y narraciones autobiográficas, entrevistas narrativas o dialógicas, documentos personales o de vida, relatos biográficos, testimonios; es decir, cualquier forma de reflexión oral o escrita que utiliza la experiencia personal en su dimensión temporal. (Bolívar et al., 2001, p. 18)

El relato se define como el producto o resultado escrito o hablado que nos ofrece información sobre el fenómeno que se investiga y la narrativa es el método de la investigación como forma de construir/analizar los fenómenos (Clandinin y Connelly, 2000). Por tanto, la narrativa designa la cualidad estructurada de la experiencia vista como relato; es tanto una estructura como método para recapitular experiencias.

Entendemos como narrativa la cualidad estructurada de la experiencia (moral) entendida/ vista como un relato; por otro (como enfoque de investigación), las pautas/formas de construir sentido, a partir de acciones temporales personales, por medio de la descripción y análisis de los datos biográficos. Es una particular reconstrucción de la experiencia, por la que -mediante un proceso reflexivo- se da significado a lo sucedido o vivido. Trama argumental, secuencia temporal, personaje/s, situación, son constitutivos de la configuración narrativa. (Bolívar, Segovia, Fernández, s.f.)

Ricoeur (1995) aporta el status epistemológico de la narrativa al señalar que en el relato el sujeto repiensa y reinventa su vida, tomando autoría de los hechos $y$, por tanto, pudiendo inaugurar posibilidades de actuación futuras distintas. Es así como la característica propia de la autobiografía es ser una construcción y configuración de la propia identidad, más que un relato fiel de la propia vida, que siempre están en proyecto de llegar a ser.

Cada modelo de relato de vida muestra una perspectiva del "yo" recogiendo -en diferentes porciones- partes de una realidad (personal, social, ideal, oculta o real) que, al confrontarla dialécticamente, surge un nuevo yo reconstruido. (Bolívar et al., 2001, p. 38)

Por su parte, Ferraroti (1983) y Denzin (1989) señalan la importancia de vincular la historia de vida con lo social, lo histórico y lo político que le da sentido o lo sobredetermina; de tal manera que no es un sujeto aislado, sino 
que está inmerso en un lugar y tiempo específico (citados en Bolívar et al., 2001). Por tanto, la narrativa se inscribe en la recuperación del sentido comunitario frene al individualismo liberal de la modernidad.

Pues son las historias y relatos comunes, transmitidos por tradiciones culturales, las que crean comunidades de sentido y creencias, en las que se inscribe cada persona. Siguiendo a Taylor, se plantea la necesidad de una comunidad de vida primaria, que haga posible la vivencia de un conjunto de bienes/virtudes compartidos, a partir de los cuales formar/entender los relatos de nuestras vidas. Sin estos principios comunes vividos, no habría lugar de donde partir, siendo yo en gran medida lo que he llegado a ser de lo que he heredado. (Bolívar et al., 2001, pp. 94-95)

Por otro lado, la investigación narrativa en educación es interdisciplinaria. Es un lugar de encuentro donde confluyen e interactúan diversas ciencias humanas y sociales: la filosofía hermenéutica, la sociología, la teoría lingüística, retórica y literaria, la historia oral, la antropología social, la etnografía y la psicología narrativa.

Todas ellas coinciden en cuanto se interesan en los modos como los humanos dan significado a su mundo mediante el lenguaje. En ese sentido, la educación -más que una disciplina- es un campo de estudio. (Shulman, 1988, citado en Bolívar et al., 2001, p. 53)
Desde la perspectiva de la transdiciplinariedad, el presente trabajo busca abordar los procesos de formación de los docentes en servicio desde la particularidad de su ser como sujetos en formación y sujetos formadores, en sus formas de pensar y representar la práctica educativa; así como en la significación que cobra en un contexto plural y multirreferencial, como proceso vital, esto es, inscrito en una historia de vida que le dé sentido.

El método biográfico irrumpe así en el campo de las ciencias sociales cobrando resurgimiento de su aplicación en la investigación durante las últimas décadas. En un inicio se circunscribió a documentos cuyo objeto de estudio era los valores, pero poco a poco se fue ampliando hacia otros centros de interés como los documentos personales que reflejan una trayectoria humana o que dan noticia de la visión subjetiva que los sujetos tiene de la realidad circundante, así como su propia existencia. Recientemente se aplica para estudiar grupos minoritarios o marginales (Pujadas, 1992, p. 26).

Como principales ventajas se tiene que nos introduce en el universo de las relaciones sociales primarias y es un instrumento valioso para el estudio del cambio social.

El método biográfico, en sus formas de relatos personales o historias de vida:

son una especie de termómetro que nos permite mostrar la complejidad extrema de las trayectorias vitales de los sujetos (y también de los grupos primarios [...]), mostrando la irreductibilidad 
(parcial) de estos procesos a los modelos normativos de la sociedad. (Pujadas, 1992, p. 43)

De acuerdo con Pujadas (1992), la historia de vida es un relato autobiográfico mediante "entrevistas sucesivas, en las que el objetivo es mostrar el testimonio subjetivo de una persona en la que se recojan tanto los acontecimientos como las valoraciones que dicha persona hace de su propia existencia" (pp. 47-48). Este método, desde una perspectiva multicéntrica, puede aplicarse al estudio de un sector socio-profesional y también a la formación social de dimensiones demográficas y culturales restringidas (comunidad). Este sería el procedimiento para este estudio en particular.

"La idea central del procedimiento consiste en hacer converger los relatos personales hacia un punto central de interés, hacia un tema común, del que todos los sujetos han sido a la vez protagonistas y observadores externos" (Pujadas, 1992, p. 56).

\section{Principios metodológicos}

- La biografía requiere una mediación entre la historia individual y la historia social (otras personas y entorno) por lo que no hay un relato único sino más bien polifónico de diversos actores en los que el valor que tenga la propia subjetividad y la experiencia humana son la base para construir conocimiento.

- Comprender el desarrollo biográfico como el producto de un doble movimiento: las vi- das de los individuos (y sus discursos) son el producto de la acción social de esos individuos y, a su vez, del determinismo social de las estructuras.

- Tener cuidado de no caer en "la ilusión biográfica" (Bourdieu, 1989) en el sentido de confundir el relato de vida con la vida misma (citado en Bolívar et al., 2001, pp. 124-127).

La cuestión de la "verdad" en narrativa que no pretende escrudiñar o establecer el carácter objetivamente verdadero de los hechos, buscando verificar lo que dice el relato; sino reflejar de la mejor manera cómo ha sido vivido subjetivamente por el sujeto. El relato no es nunca lo que sucedió, sino una interpretación (variable por lo demás en el tiempo) de nuestra propia experiencia. Por tanto, las narraciones no reflejan, sino que construyen la realidad (Bolívar et al., 2001, pp. 142-144).

Es preciso, por tanto, diferenciar entre "verdad histórica", como correspondencia entre los hechos descritos con los sucesos ubicados en determinados tiempos y espacios; y "verdad narrativa" que se refiere a lo que es sentido, captado y expresado con coherencia, verosimilitud, autenticidad o convicción.

Tanto la autobiografía como la historia de vida podrían confundirse, por lo que, Denzin (1986) hace una distinción importante entre ambas:

- El "Relato de vida" ("life-story" en inglés, "récits de vie" en francés) es una narración 
(retrospectiva) por el propio protagonista de su vida o de determinados fragmentos/ aspectos de ella, por iniciativa propia 0 a requerimiento de uno o varios interlocutores. En este caso, la historia de vida es tal y como la cuenta la persona que la ha vivido.

- La "Historia de vida" ("Life-history" en inglés, "histoire de vie" en francés), es una elaboración (por biógrafos e investigadores) como estudio de caso de la vida de una/s persona/s o institución, que puede/ $\mathrm{n}$ presentar diversas formas de elaboración y análisis.

La distinción tiene relevancia metodológica porque, como indica Goodson (1996), «si la 'life-story' individualiza y personaliza, la 'life-history' contextualiza y politiza». El relato inicial que una persona hace de su vida debe ser contextualizado y complementado con otras fuentes (testimonios de otras personas, testimonios documentales, transcripciones 0 archivos relacionados con la vida/s en cuestión) para comprender los patrones de relaciones sociales, construcciones e interacciones en que la vida está envuelta. El primero es una narrativa de acciones, el segundo una genealogía del contexto. Una historia de vida (life-history) tiene el propósito deliberado de definir el desarrollo de una persona en un medio cultural, dándole una comprensión teórica. (Bolívar et al., s.f., s.p.)

\section{Narrativas y ejes de análisis}

\section{Imaginarios}

En la sociología, lo simbólico hace referencia a significaciones, construcciones de sentido que organizan la acción de los hombres y que instituyen a las sociedades. Para Castoriadis (2002) esto significa "el imaginario", es decir, todo lo que es portador de sentido, no únicamente el lenguaje. Sin embargo, esta referencia totalizadora del imaginario remite a la imposibilidad de ser conocida, por lo que se considera que, para los relatos de vida, la identificación de las significaciones y la búsqueda de sentido (individuales y colectivas) están siempre presentes, ya sea explícita o implícitamente en sus discursos, toda vez que éstas permiten el despliegue de los procesos de identidad en cada sujeto y en cada grupo social.

Las instituciones se encargan de crear, recrear o modificar las significaciones, que de igual forma son compartidas, para lograr la permanencia y sostenimiento de la sociedad. Esta necesidad social e individual de buscar un sentido y que sean compartidos responde a una lógica ensídica, es decir, una lógica de lo que está establecido y que se acepta como "verdadero". Los principales agentes socializantes de la construcción de la verdad son instituciones como la familia, la iglesia, la escuela y los medios de comunicación; son portadores de significaciones que no se refieren ni a la realidad ni a la lógica y que Castoriadis denomina "significaciones imaginarias sociales", mismas que se 
cristalizan o se solidifican desde un imaginario social instituido.

Por otra parte, se considera también la imaginación del ser humano singular como la determinación esencial (la esencia) de la psique humana, puesto que es imaginación radical en el sentido de que es ola o flujo incesante de representaciones, deseos y afectos. Está ahí como una fuerza que puede o no ser explicada y que lleva a los individuos a realizar cualquier acto dotado de sentido. A este tipo de imaginación se le llama imaginación radical o instituyente.

Imaginario porque la historia de la humanidad es la historia del imaginario humano y de sus obras. Historia y obras del imaginario radical que aparece apenas existe una colectividad humana: imaginario social instituyente que crea la institución en general (la forma institución) y las instituciones particulares de la sociedad considerada, imaginación radical del ser humano singular. (Castoriadis, 2002, p. 93)

En síntesis, sin pretender abarcar la complejidad de la teoría social de Castoriadis, se recurre a "lo imaginario" como referente categórico para el análisis debido a la importancia del papel que desempeña en la conformación de la identidad de los sujetos entendida como un "entrecruzamiento de diversas dimensiones imaginarias" (Anzaldúa, 2004 , p. 369). Con este argumento, se puede decir que es a través de las "significaciones sociales" como se puede comprender el sentido que le atribuyen los sujetos a su experiencia y a sus acciones.

Se parte de la premisa de que en todo relato de vida existe un conjunto de significaciones sociales que le da sentido y justifica lo instituido sin cuestionamiento previo; así como una imaginación individual radical que dirige el pensamiento de los sujetos hacia el análisis, la reflexión para la actuación frente a situaciones adversas.

\section{Secretos colectivos}

Berenzon (1999) aborda el concepto de "secretos colectivos" como fenómenos culturales que se instalan en el plano del inconsciente social y emergen en los discursos de los sujetos a través de los cuales se recuperan las significaciones valiosas para la comunidad y que son transmitidas de generación en generación.

Estos secretos colectivos emergen en los discursos de los sujetos y permiten recuperar dichas significaciones sociales valiosas para la comunidad y que son transmitidas de generación en generación.

La manera como un sujeto se comunica con otros, la manera en que se construyen las "novelas" o "mitos" familiares de forma individual en los sujetos, a partir de la constelación social donde se hallan insertos, y cómo se transmiten de generación en generación los significantes privilegiados de un grupo social, configurando de modo particular el pensar, actuar y sentir de sus integrantes. (Berenzon, 1999, p. 57) 


\section{Identidades}

Al identificar las significaciones sociales se puede dar respuesta a algunas cuestiones como: ¿Por qué este sujeto piensa así? ¿̇con base en qué creencias o suposiciones justifica su actuar individual, familiar o social?, ¿quién le transmitió esa forma de pensar?, ¿dónde adquirió ese conocimiento?, ¿en qué momento histórico?, ¿bajo qué circunstancias? Es decir, ¿̇cómo argumenta el sentido de sus acciones? ¿ ¿cómo arma su relato de tal manera que sea coherente y justifique su pensamiento y su poder de decisión?

Se considera que a través de estas significaciones sociales se pueden entender algunas interrogantes con respecto a los procesos de identidad en los individuos: ¿̇cómo se constituye como sujeto?, ¿cómo se define a sí mismo?, ¿ ‘ómo elabora su relación con los otros? ¿cómo responde a la pregunta acerca de "quién soy yo" y "quiénes son los otros"? ¿̇cuántas y cuáles formas de "yo" se construyen a partir de su experiencia vital?, ¿̇cómo construye su "yo" a partir de los otros y de sí mismo? y ¿̇cómo interviene en la construcción de los "yo" de los otros?

Se tiene, entonces, una relación directa entre las significaciones sociales y la construcción de los procesos de identidad de los sujetos, porque para cada contexto hay un "yo" distinto y para cada momento o etapa vivida hay diferentes "yo", fundados y reconstruidos permanentemente.

Se entiende por identificación a dos procesos inseparables: por un lado, al proceso por el cual un grupo o una persona se reconoce como idéntico (similar, semejante) a otro. Este movimiento de significación va de "adentro" hacia "afuera"; por otro lado, se da un proceso por el cual otro(s) identifica(n) a un sujeto confiriéndole determinada cualidad. Este movimiento de significados va de "afuera" hacia "adentro" y va a constituirse en arte de la propia identificación del grupo, en razón de la capacidad de interpelación que tengan "adentro" los significados gestados "afuera". (Aguado y Portal, 1992, p. 48)

En ese sentido, las diferencias individuales son una característica esencial de la especie humana y la manera de ser concebidas obedece a un proceso histórico-social, siendo este último el que ha determinado las relaciones entre los sujetos y sus formas de desarrollo y aprendizaje. Este principio posibilita abordar los procesos de identidad cuestionando "a los otros" que son los que definen al "yo" (alteridad) convirtiéndolos en el "yo" que participa en la constitución del "otro".

\section{Epifanías o incidentes críticos}

Las epifanías o momentos críticos de la vida son otro elemento importante en el proceso vital de un individuo en función de que marcan particulares direcciones como momentos que acentúan determinados cambios de rumbo.

Se intenta adoptar una perspectiva focalizada en los principales "hitos" significativos, que a modo de pivotes, caminos o rupturas las han ido 
jalonando. Puesto que en el desarrollo normal de una vida se suelen reconocer determinados acontecimientos vividos o que desde su experiencia han producido un "corte" o "trauma" de especial significación personal o social, contribuyendo a cambiar/girar su trayectoria de vida o identidad. Suponen pues, puntos de reflexión en la vida descrita y que pueden actuar positiva o negativamente en la misma. (Bolívar et al., 2001, pp. 173-174)

Denzin (1986) define los incidentes críticos como momentos de crisis que tienen un carácter personal y que alteran las estructuras de significados fundamentales en una vida. Señala a su vez, cuatro formas de manifestación:

1. cambio radical, en la medida que afecta la estructura global de la vida;

2. cambio durativo, es la serie de acontecimientos que se han vivido a lo largo de un período dilatado de tiempo;

3. cambio accidental, representa un momento problemático importante, pero episódico, en la vida;

4. cambio revivido, aquellos episodios biográficos cuyo significado se le otorga al reconstruir (narrar) la experiencia.

El interés por las epifanías proviene de permitir delimitar fases críticas y momentos de cambio, impacto o cambio de rumbo, personas importantes, información contextual cultural, relaciones causales, valoraciones y sentido.
Las significaciones sociales pueden ser identificadas a través de expresiones como: la gente (los otros) dice(n), piensa(n), cree(n), o impersonal: se dice, se cree, se piensa -en sus distintos tiempos y modos verbales-. La imaginación individual radical se encuentra en frases iniciales tales como: yo creo, yo pienso, yo me imagino, quizás, tal vez -en sus distintos tiempos y modos verbales-; en el empleo de la lengua, de la enunciación que es "este poner a funcionar la lengua por un acto individual de utilización" (Benveniste, 2004, p. 83), de apropiación y de producción.

Se considera que las principales epifanías que son comunes en todo proceso vital son: el nacimiento propio o de otro(s), el ingreso a la escuela, el término con éxito de, o el abandono y fracaso en la vida escolar, la inserción al trabajo, el matrimonio o unión de pareja, algunas enfermedades y la muerte.

La identidad se va a construir a partir del otro: ¿̇qué quiere de míl ¿̀dónde me quiere?, ¿̇qué tengo que ser para existir?, ¿̀dónde me tengo que poner? Esta constitución del sujeto es imaginaria y depende del deseo de los otros. Pero, ¿quién es el otro? El "otro" es el semejante, el representante del orden social y cultural. El otro es el yo introyectado de la sociedad y la cultura (lo simbólico) en este otro en un entorno real.

Los procesos de identidad se reconocen por frases en primera persona acompañados de dos verbos principales: ser y estar; ubicados en determinada etapa individual y social e insertos en tiempos y espacios específicos. Hay 
un yo niño, un yo joven, un yo adulto, un yo anciano, un yo hijo, un yo padre, un yo hermano, como parte de una familia, de una escuela, de un lugar de trabajo, de una comunidad, de una ciudad, de un país; un yo estudiante, un yo trabajador, un yo desempleado, un yo emigrante, un yo sedentario. Todos ellos como formas de pertenencia y no pertenencia, como formas de inclusión o exclusión social, laboral o educativa. 


\section{CAPÍtULO 3}

\section{Lugares y sujetos del medio rural}

\section{Lo rural, tierra de contrastes y diversidad}

La modernidad ha llegado a los principales lugares de la zona rural. Los medios de comunicación y transporte son la base de la infraestructura que respalda el progreso económico en medio de una aceptada crisis permanente. Las cabeceras municipales de las diferentes regiones de los estados apuntalan para convertirse, en un tiempo no muy lejano, en las nuevas ciudades del siglo XXI, dos siglos después del México Independiente y uno posterior al naciente Estado Moderno del siglo XX. El México rural se está convirtiendo por los signos de la urbanización en una mezcla de núcleos de modernidad económica en medio de regiones dispersas con una gran diversidad social.

¿Qué significa entonces el "medio rural"? Ante lo descrito, ya no puede hablarse del medio rural como un concepto anacrónico, por el contrario, al caracterizarse como la interrelación entre el ambiente natural y la cultura de un grupo social en tiempos y espacios específicos, se le define desde una perspectiva histórico-social que se refleja en sus condiciones geográficas y demográficas y que desde lo histórico, social y cultural confluyen en una serie de "ensamblajes" donde es difícil distinguir lo autóctono de lo extranjero, lo tradicional de lo moderno, lo rural de lo urbano; de tal forma que ya no puede hablarse de un medio rural en general, sino de múltiples y variadas expresiones de lo rural y las formas como se incorporan los procesos de urbanización.

\section{El estado de San Luis Potosí}

El estado de San Luis Potosí se localiza geográficamente en la región centro norte del país en una superficie de $62,848 \mathrm{~km}^{2}$, lo que represen- 
ta el $2.41 \%$ del total. Tiene límites vecinales con nueve estados, al norte con Coahuila, Nuevo León, Tamaulipas y Zacatecas, al sur con Guanajuato, Hidalgo y Querétaro, al este con Veracruz y al oeste con Zacatecas. Su organización político-administrativa se integra por 58 municipios, con 5,299 localidades, de las cuales sólo ocho son consideradas urbanas. El estado se divide en tres regiones naturales: la llanura costera del golfo, la Sierra Madre Oriental y la mesa del centro. En el aspecto administrativo, se divide en cuatro regiones: centro, altiplano, media y huasteca (Calvillo, 2002, p. 11).

Cuando se realizó este estudio, ciclo escolar 2005-2006, la población total del estado de San Luis Potosí era de 2,299,360 habitantes, de los cuales aproximadamente el $50 \%$ eran hombres y el otro $50 \%$, mujeres, con una diferencia relativamente mínima de $+57,686$ mujeres sobre los hombres. El índice de alfabetismo era de $88.6 \%$. De su población total, el $2.1 \%(48,190)$ tenía alguna discapacidad ${ }^{1}$ $(25,375$ hombres y 22,815 mujeres). Así, se tienen los siguientes datos: 20,443 con discapacidad motriz, 8,597 con discapacidad auditiva, 2,610 con discapacidad del lenguaje, 14,198 con discapacidad visual, 7,284 con discapacidad mental, 376 con "otra" y 174 no especificado. Un total de 839,935 habitantes se encontraban en un rango de 0 al4 años, señalándose que el $0.8 \%$ (un poco menos de ocho mil) presentaban discapacidad (INEGI, 2000).

Actualmente, la población total del estado de San Luis Potosí es de 2,717,820, es decir, ha habido un incremento de 488460 habitantes (21\% aproximadamente); de los cuales, $1,400,295$ son mujeres $(51.5 \%)$ y $1,317,525$ son hombres $(48.5 \%)$, con una diferencia de 82,770 entre ambos (INEGI, 2015a). El índice total de población alfabetizada se ha incrementado a 94\%. De igual forma, en el rubro "Salud y Seguridad social", se encuentra el indicador de discapacidad en donde se señala que, según el censo 2010, se tiene un total de personas "con limitación en la actividad" de 117,700 $(4.3 \%)$, es decir, ha habido un incremento del $2.2 \%$ (INEGI, 2015b), como se muestra en la tabla 1.

Como puede observarse, el incremento ha sido proporcional: del $21 \%$ del total de población, ha habido un incremento de $2.2 \%$ de población con discapacidad; lo anterior permite pronosticar su probable aumento como una constante a mediano plazo. Por otro lado, resulta significativo cómo desde estos datos oficiales se caracteriza a la población "con alguna limitación" y se inscribe en el rubro de "Salud y Seguridad Social", no en el de "Educación".

1 Oficialmente, se utiliza el término: "personas con discapacidad"; en este trabajo y desde nuestra perspectiva se denomina a esta población: "sujeta al proceso de inclusión". 
Población total que no especificó limitación en la actividad 35,161

Población con limitación en la actividad para escuchar 15,317

Población con limitación en la actividad para hablar o comunicarse 11,390

Población con limitación en la actividad para caminar o moverse 63,758

Población con limitación en la actividad para atender el cuidado personal 6,973

Población con limitación en la actividad para poner atención o aprender 6,633

Población con limitación en la actividad 117,700

Población con limitación en la actividad para ver 33,856

Población con limitación en la actividad mental 12,157

Población total con limitación en la actividad

117,700

Nota: La suma de los distintos tipos de limitación en la actividad puede ser mayor al total por aquella población que tiene más de una limitación. Las cifras corresponden al Censo de Población y Vivienda 2010. Fuente: INEGI (2015b).

\section{Mexquitic de Carmona}

Mexquitic de Carmona ${ }^{2}$ es un municipio situado al oeste del estado de San Luis Potosí, México. El pueblo, fundado hacia 1587, se dice que es cuna de San Luis Potosí pues fue el primero que se congregó. Actualmente, es la cabecera municipal y se encuentra a $20 \mathrm{~km}$ de la ciudad capital. Se caracteriza por ser una zona árida y pedregosa. "La mayor parte está ocupada por cerros muy erosionados de escasa altura y lomas pedregosas, pero por la parte que le corresponde del Valle del Tangamanga, hay tierras aprovechables para el cultivo" (Turrubiartes, Grimaldo y Pecina, 2001).

Sus cerros contienen estaño y cristales de cuarzo, mercurio, fierro meteórico, cinabrio y ópalo común. "Es un terreno agreste, de rocas y peñascales, situado muy estratégicamente, por lo que se comprende que haya sido elegido por los Guachichiles ${ }^{3}$ para su morada" (Turrubiartes et al., 2001).

2 Nombrado así por: Mexquitic, palabra de origen náhuatl que significa "lugar entre árboles de mezquite"; de Carmona, en honor a Damián Carmona, ilustre potosino nacido en ese lugar.

3 Etnia nómada descendiente de los chichimecas. 


\section{Historia}

Los aborígenes del lugar [...] eran nómadas salvajes, los hombres andaban desnudos y las mujeres andaban fajadas con unos cueros de venado. Todos ellos eran recolectores o cazadores crueles en extremo, caníbales que se colgaban como trofeos el cuero cabelludo de sus oponentes, según se describe en "La guerra de los Chichimecas". (Pedraza, 1994, p. 2)

Peña (1894) señala que, en 1590, Mexquitic fue un lugar estratégico. En el aspecto militar, sirvió como lugar de defensa y de concertación de los chichimecas al estar al mando de la dominación española Don Miguel Caldera ${ }^{4}$. En el aspecto religioso, sirvió como lugar de evangelización de los indígenas por parte de Fray Diego de la Magdalena. Por último, en el aspecto político, el Virrey Don Luis de Velasco trató de unificar los pueblos al enviar tlaxcaltecas para que se incorporasen con los chichimecas -una vez sometidos-, por lo que denominaron al lugar: la Nueva Tlaxcala Tepeticpac, La Grande.

Sosegados los indios comenzaron a entregarse de paz, y bajo la custodia de los misioneros franciscanos se establecieron, por lo que, respecto a esta comarca, en San Luis Miguel de Mexquitic [...] hacia el año 1589 [...] Situado a cinco leguas al noroeste de San Luis Potosí es una de las poblaciones más antiguas en el es- tado del mismo nombre. En los primeros meses de 1592 el padre Fray Francisco Franco, guardián entonces del convento, dio aviso al capitán Caldera de unas minas que existían en las montañas al oriente del referido pueblo y que un guachichil le había dado a conocer. (Peña, 1894, pp. 3-5)

Este suceso dio origen a la búsqueda y exploración del Cerro de San Pedro en el que, al ser descubiertas sus minas fueron repartidas y explotadas por los conquistadores. La necesidad de agua y condiciones más favorables para vivir, los hicieron emigrar para establecerse en lo que ahora se conoce como la ciudad capital del estado de San Luis Potosí, desplazando a sus moradores indígenas hacia el norte del lugar que ahora se conoce como el barrio de Tlaxcala, con la condición expresa del Virrey de que no se les molestara o atacara para una convivencia pacífica (Pedraza, 1994, pp. 1-3).

Mexquitic de Carmona, al igual que muchos pueblos prehispánicos fue:

una mezcla de conquista de explotación mineral, civilizadora y cristianizadora, cuyo fin era lograr la redención del bárbaro, ya fuera a través del sometimiento por medio de la fuerza o de la persuasión de la razón y la adhesión de la voluntad, al concebir como diabólica la idolatría que practicaban los nativos. (Pedraza, 1994, p. 35)

4 Personaje importante en la pacificación de las tribus de indios guachichiles. 


\section{Demografía}

Cuando se hizo este estudio, ciclo escolar 20052006, este municipio tenía una población de 48,392 habitantes, 23, 123 hombres y 25,269 mujeres, con una edad mediana de 18 (hombres 17, mujeres 19). Respecto a los rangos de edad, 19,937 eran menores de 15 años; 12,365 estaban en un rango de 6 a 14 años (6,253 hombres y 6, 112 mujeres). Respecto al alfabetismo, 10,210 habitantes sabían leer $y$ escribir y 2,114 no sabían leer y escribir, 41 aparecían con el rubro: "no está especificado". Asimismo, el índice de población de 15 años y más era de 28,128 , con un porcentaje de alfabetismo de $86.1 \%$ (INEGI, 2000). Actualmente, su población total es de 57,184, 52\% son mujeres y $48 \%$ son hombres; es decir, hay una variación de $+8,792$. El índice de alfabetismo es de $92.89 \%$ y el $68 \%$ de su población de 15 años o más cuenta con educación básica (INEGI, 2015c).

Durante el período de trabajo de campo, la población económicamente activa (PEA) en el municipio de Mexquitic era de 11,653 (36.5\%) y la población económicamente inactiva era de 20,266 (33.5\%). La población ocupada en el sector primario abarcaba las actividades de agricultura, ganadería, silvicultura, caza o pesca; el sector secundario se incluía la minería, la generación y suministro de electricidad y agua, la construcción o industria manufacturera; en el sector terciario se tenía el comercio, el transporte, los servicios financieros, ofrecimiento de servicios profesionales, en el gobierno u otros servicios (INEGI, 2000). Hoy en día, el $20.2 \%$ de la población económicamente activa se dedica al sector agropecuario; el $36.4 \%$ al sector secundario, con actividades como la industria, la industria manufacturera, industria de la construcción e industria energética; $42.8 \%$ se ocupa en el comercio y servicios; y un $0.6 \%$ no es especificado (Secretaría General de Gobierno, 2013, p. 35). En ese sentido, ha sido interesante ver cómo en el sector productivo del municipio está dejando de ocupar un lugar predominantemente el sector primario, para ir desarrollándose en actividades de los sectores secundario y terciario. No obstante, según estimación del Consejo Nacional de Evaluación de la Política de Desarrollo Social (CONEVAL), actualmente el indicador de población en situación de pobreza es del $67.6 \%$, en condición de pobreza moderada es del $49.3 \%$ y en condición de pobreza extrema es del 18.2\% (Secretaría General de Gobierno, 2013, p. 31).

Durante el ciclo escolar 2005-2006, el $74 \%$ de las viviendas eran construcciones que cubrían las condiciones adecuadas en paredes, techos y pisos con materiales como: cemento, mosaico, madera y otros recubrimientos. El $26 \%$ restante se distribuye entre las viviendas que carecían de alguno de éstos. No incluía a la población de viviendas sin información de ocupantes y a los refugios. El $44 \%$ del total de viviendas particulares habitadas contaban con servicio sanitario exclusivo, el $64 \%$ disponían de agua entubada, el $25 \%$ de drenaje y el $86 \%$ contaban con energía eléctrica. Sólo el $20 \%$ te- 
nía los servicios de drenaje y agua entubada y el $24 \%$ sólo contaban con drenaje y energía eléctrica. Otro dato fue el empleo de gas para cocinar $(57 \%)$, leña $(41 \%)$ y menos del $1 \%$ utilizaba carbón o petróleo (INEGI, 2000). En la actualidad, se observa en general, un incremento con relación a la mejora de las condiciones de servicios, por ejemplo, la disponibilidad de agua entubada y acceso al agua es de $90.41 \%$ y por acarreo del $9.48 \%$ (INEGI, 2016).

La religión que predominaba en el municipio era la católica $(98.2 \%)$, el $1.8 \%$ restante pertenecía a una religión no católica o bien se declaraba sin creencia religiosa alguna (INEGI, 2000). Hoy en día sigue predominando este tipo de religión, sin embargo, se observa una disminución de su indicador y un ligero aumento en religiones no católicas o sin creencia alguna (INEGI, 2016).

Con respecto a las comunicaciones y transportes, en el 2005, se estaba construyendo la autopista San Luis Potosí-Zacatecas, cuyo tramo en construcción se encontraba en los kilómetros 15 al 20, es decir, a la altura de la cabecera municipal; y más adelante, a la altura del entronque con el municipio de Ahualulco, por lo que la reducción de tiempos y costos en el transporte ha beneficiado ampliamente a la región. Los caminos para llegar a las comunidades más cercanas a la capital que no estaban a bordo de carretera tenían condiciones regulares, aunque les faltaba mantenimiento, sin embargo, se podía acceder a ellas con vehículos particulares; además, se contaba con servicio colectivo de dos líneas de autobuses y "combis" de manera periódica (cada 30 minutos en promedio). Para desplazarse a lugares cercanos se empleaba la bicicleta y, en menor proporción la motocicleta; aunque era todavía una práctica común la caminata para distancias relativamente largas. Actualmente, este rubro refleja una notable mejora, aun cuando hay un déficit en el mantenimiento de sus vías de transporte como carreteras y caminos al interior del municipio.

Respecto al tema de discapacidad, un total de 1,108 habitantes (576 hombres y 532 mujeres) presentaban algún tipo de limitación; 152 eran menores de 15 años y se distribuían de la siguiente manera: 49 con discapacidad motriz, 20 con discapacidad auditiva, 23 con problemas de lenguaje, 37 con discapacidad visual, 36 con discapacidad mental, 4 con otro tipo de discapacidad y 1 no especificado (INEGI, 2000). En el censo 2010 y la encuesta intercensal 2015 no se encontraron indicadores al respecto.

En el período de estudio, las tres primeras comunidades con mayor índice de población con discapacidad fueron: El Palmar Primero, San Marcos Carmona y Corte Primero. El Palmar Primero tenía la mitad de población que San Marcos Carmona (1,254 y 2,012, respectivamente) y el doble de personas "con discapacidad" (96 y 51, respectivamente). En general, se presentaba mayor porcentaje en la población con discapacidad motriz (89), seguida de discapacidad visual (64); discapacidad auditiva (30) y, en menor porcentaje, discapa- 
cidad mental (17) y discapacidad de lenguaje (10) (INEGI, 2000). ${ }^{5}$

Las comunidades El Palmar Primero, Corte Primero y San Marcos Carmona, también se encontraban entre las primeras localidades que presentaban mayor número de niños y jóvenes entre los 6 y 14 años que no saben leer ni escribir, lo que podría suponer una relación directa. Sin embargo, había un porcentaje que pareció indicar que esta población analfabeta $(77,73$ y 71 , respectivamente) no asistía a la escuela y no presentaba alguna discapacidad $(20,45$ y 23 , respectivamente), por lo que la población que sí la presentaba debería, (desde una lógica de sentido común), ser parte de la población que no estaba en las escuelas $(96,51$ y 42 , respectivamente).

\section{Comunidades, escuelas y sujetos del medio rural} Para el trabajo de campo, los centros seleccionados fueron tres escuelas integradoras ubicadas en las comunidades de: Guadalupe Victoria, Corte Primero y Mexquitic de Carmona (cabecera).

Estas escuelas, al pertenecer al programa oficial de integración, contaban con el apoyo de educación especial, eran de organización completa, con un promedio de 110 padres de familia y 232 alumnos. Esto significaba que eran escuelas que contaban con una buena infraestructura material y con los recursos humanos suficientes y necesarios.

Desde 1986, el municipio de Mexquitic de Carmona ha contado con una Unidad de Servicios de Apoyo a la Escuela Regular (USAER 15), la cual pertenece al Sistema Federal Transferido y atiende alumnos de educación preescolar y primaria que requieren educación especial. Esta unidad estaba compuesta por diez docentes especialistas, un equipo paradocente $\circ$ interdisciplinario (psicólogo, trabajador social y especialista en comunicación y lenguaje) y un director. En sus primeros años sólo se atendía a alumnos repetidores de primer grado o que mostraban dificultad en la adquisición de la lectoescritura y el cálculo elemental a través de la creación de los llamados "grupos integrados". Los docentes especialistas trabajaban en las escuelas donde había alumnos "con necesidades educativas especiales" y el equipo interdisciplinario los auxiliaba siguiendo un itinerario de visitas, correspondiendo en promedio dos visitas por mes a cada grupo. En la década de los noventa, el servicio se extendió a la creación de "grupos de apoyo" que ofrecía atención especial a alumnos de $2^{\circ}$ a $6^{\circ}$ grado que mostraran dificultades en lectoescritura y/o matemáticas. Después del año 2000, se inició

5 Hay un estudio de la UASLP que ha relacionado los factores de contaminación ambiental en agua, suelo y aire con problemas de salud, reproducción y alteraciones que generan discapacidad auditiva e intelectual, principalmente en el sector noroeste de la ciudad capital de San Luis Potosí, por la cercanía que se tiene con la planta de cobre ahí instalada (Díaz-Barriga, F., Batres, L., Carrizales, L. Mejía, J. y Calderón, J., s.f.). 
el apoyo al nivel de preescolar. Durante todo este tiempo, la USAER 15 había prestado sus servicios en algunas comunidades de manera continua, en otras había sido de forma intermitente, sin embargo, la mayoría no habían contado con este servicio.

En cuanto a los sujetos, se trabajó con los niños que pertenecían al programa de integración educativa de las tres escuelas mencionadas. A los directivos, los docentes y los padres de familia se les hizo la invitación para participar, de manera libre y voluntaria, con sus relatos de vida de manera oral o escrita. Hubo una respuesta positiva para trabajar con entrevistas orales; no así con escritos autobiográficos, pues ninguno de los cinco sujetos que dijeron que lo elaborarían, lo entregaron, por tanto, se recabaron solamente 15 relatos orales.

Los alumnos incluidos estaban distribuidos en alguno de los seis grados, encontrando cierta congruencia con su edad cronológica. El procedimiento para formar parte del grupo de apoyo era a través de la "canalización" del maestro de grupo regular al considerar que requerían de atención especial. De esta manera, participaba todo el personal: directores y docentes, por lo que la escuela se denominaba: "integradora"; sin embargo, eran los maestros, quienes atendían a los alumnos integrados en el grupo regular, los que participaban de manera directa en el programa.

La maestra de apoyo definía cuál era la necesidad educativa del alumno y la caracterizaba con relación a la existencia o no de una "discapacidad"; esta última determinaba, a su vez, las áreas de atención involucradas, que podían ser sólo una o bien las tres: trabajo social, psicología, o lenguaje y comunicación. La directora coordinaba el trabajo interdisciplinario en el equipo y establecía comunicación directa con el director de la escuela para informar sobre las acciones realizadas con los alumnos, docentes y padres de familia. Para el ciclo escolar 2004-2005, la USAER 15 reportó una inscripción de 222 alumnos: 20 en el nivel de preescolar (11 hombres y 9 mujeres), 202 en primaria (1 16 hombres y 86 mujeres).

El trabajo consistía, además del apoyo individual a los alumnos con necesidades educativas especiales, en trabajo grupal o en equipos pequeños, en la asesoría a los maestros de la escuela regular y el trabajo con los padres de familia.

Las necesidades educativas especiales de los alumnos de preescolar no se asociaban con alguna discapacidad; por otra parte, en primaria se reportaban 11 alumnos con discapacidad: ocho hombres (uno con sordera, uno con discapacidad motriz, cinco con discapacidad intelectual y uno no especificado) y tres mujeres (con discapacidad intelectual). Estos alumnos se encontraban distribuidos en cuatro escuelas: cuatro en Mexquitic de Carmona (cabecera), tres en la Comunidad de Guadalupe Victoria y cuatro en la Comunidad de Corte Primero. Fue en estas escuelas donde se desarrollaron los casos que se presentan en el presente libro. 


\section{CAPÍtULO 4}

\section{Narrativas y experiencias de inclusión educativa en el medio rural}

En este capítulo se presentan tres casos del proceso de inclusión educativa en el medio rural, a través de un análisis comparativo entre lo que enuncia la evaluación psicopedagógica de alumnos que pertenecen al programa de integración educativa, su maestra de grupo regular, el equipo de apoyo y/o los padres de familia, como sujetos que participan en este proceso; así como la información obtenida a través del diario de campo.

En ese sentido, fue relevante reconocer las formas de "el sujeto de la enunciación" y la "enunciación del sujeto" para definir los juicios de valor que se emiten de unos con respecto a otros. Siguiendo a Haidar (1998), se parte de la idea que el sujeto de la enunciación marca el discurso en todos los niveles, que van desde la deixis personal presente en los pronombres articulados a las primeras y segunda personas, (así como a todas las formas pronominales de éstas, y a los tiempos verbales), hasta la selección de las estructuras sintácticas, del léxico, de las modalizaciones y demás estrategias discursivas.

El primer caso: "Una verdad manifiesta" es de la comunidad Guadalupe Victoria. Se trata de describir cómo se desarrolla el proceso de inclusión educativa en el medio rural en una escuela primaria integradora, es decir, que cuenta con un programa de apoyo para la atención de alumnos "con necesidades educativas especiales", haciendo una comparación entre lo que enuncia la evaluación psicopedagógica, el relato de vida de la madre del niño, las entrevistas con su maestra de grupo regular y el 
equipo de apoyo, como sujetos que participan en este proceso, así como la información obtenida del diario de campo.

El caso permite reconocer cómo la comunidad y la escuela están pasando por un proceso que va de la "no aceptación de las diferencias" (en el cual subyacen significaciones sociales acerca de las diferencias individuales como sinónimo de "incapacidad") hacia "el reconocimiento" (no siempre consciente) de las capacidades potenciales que posee todo individuo a partir del caso de un alumno que cursa el tercer grado de primaria, quien ha ido demostrando paulatinamente, a la familia, a la escuela y a la comunidad en general que la capacidad de aprender es independiente de las características físicas de los sujetos.

El segundo caso: "El conflicto no resuelto", se desarrolla en la comunidad de Corte Primero, una de las comunidades más grandes en territorio y población del municipio de Mexquitic de Carmona; está dividida en cinco sectores, entre los cuales existen lazos de parentesco y alianzas por un lado, pero por el otro, hay una serie de rivalidades que los dividen, por lo que el rechazo hacia algunos alumnos en la escuela se inserta en un contexto de exclusión social, principalmente de las familias que pertenecen a los sectores más desfavorecidos económica y culturalmente. Se muestra una familia de este sector, al cual pertenece una alumna de 12 años que ha sido repetidora del primero y segundo grado al no lograr adquirir la lectoescritura. Para dar cuenta de este proceso, se contó con la información obtenida de la maestra de apoyo, de la evaluación psicopedagógica, del relato dirigido que la niña elabora, de los relatos de vida de los padres, así como del diario de campo.

El tercer y último caso: "Construyendo caminos y alargando distancias" es de la comunidad de Derramaderos, misma que se encuentra aproximadamente a 15 kilómetros de la cabecera municipal. En éste, se da cuenta de la dificultad que existe en el medio rural sobre las distancias y tiempos para que una niña asista a una escuela integradora (en este caso de la cabecera municipal), al considerar que es ahí donde ella puede recibir la atención que necesita, de acuerdo con sus posibilidades. Los registros del diario de campo, los testimonios de los padres y hermanos, los comentarios de sus maestras de apoyo y de grupo regular, así como del director de la escuela aportan elementos para la descripción de este caso.

\section{Guadalupe Victoria: una verdad manifiesta}

Guadalupe Victoria es una comunidad que pertenece al municipio de Mexquitic de Carmona, en el estado de San Luis Potosí, México. Es una localidad cercana a la ciudad capital que está aproximadamente a unos diez kilómetros de la zona suroeste del anillo periférico, cerca de la zona residencial "Las Lomas". Según estudios de la Universidad Autónoma de San Luis Potosí (Torres et al., s.f.) debido a los residuos y desechos tóxicos que expide la planta de zinc que se encuentra en esta área, tiene un alto índice 
de contaminación ambiental de suelo, agua y aire. Lo anterior, pone en una grave situación de riesgos de salud reproductiva y de desarrollo a su población.

Por otro lado, la escasez de agua y la mejora en las vías de comunicación y transporte ha provocado que la gente esté dejando de dedicarse a las actividades primarias como la agricultura y la cría de animales, prefiriendo desplazarse para trabajar en la ciudad en la prestación de servicios: los hombres en la albañilería y las mujeres en el servicio doméstico principalmente. De una población de 1,079 habitantes, 263 niños y jóvenes se encuentran entre los 6 y 14 años de edad (24.37\%), de los cuales no asisten a la escuela $29(11 \%)$ y que se relaciona directamente con el número de personas que se consideran sujetas al proceso de inclusión y que el censo caracteriza como "personas con discapacidad" auditiva, visual, motriz, intelectual y de lenguaje (26, según datos del INEGI, 2000) de las que no se especifican edades.

La escuela primaria se ubica en la calle principal. El relieve es inclinado y el terreno tiene una superficie de $800 \mathrm{~m}^{2}$ aproximadamente. La dirección y los salones están distribuidos en dos edificios paralelos en las partes oriente $y$ poniente. El último salón del edificio que está en la parte norte es el aula de educación especial, a un lado de ésta hay una pequeña bodega y enfrente se encuentra la biblioteca. En la parte central está una gran cancha con piso de cemento, el patio cívico y un local para la cooperativa; hacia el sur se encuentra un área con piso de tierra donde hay árboles y plantas. Atrás del edificio de salones que está al poniente se ubican los baños. En la figura 1, se observa la fachada de la escuela.

Durante el ciclo escolar 2005-2006 se tuvieron estadísticamente: 115 padres de familia, 197 alumnos y 12 integrantes del personal (un director, siete docentes, un auxiliar en primer grado, un maestro de apoyo, un maestro de educación física y un intendente). Hubo un grupo de cada grado, excepto $6^{\circ}$ grado, en el que hubo dos grupos. Se considera una "escuela integradora" porque desde hace dieciocho años aproximadamente se cuenta con el apoyo de Educación Especial a través de las unidades de "grupos integrados" $y$, posteriormente, de la USAER 15 con el programa oficial de integración educativa donde se reportaban tres alumnos registrados "con necesidades educativas especiales asociadas a una discapacidad" en la escuela regular. Aunque la directora de la USAER 15 aclara:

Tenemos escuelas integradoras: Corte, Mexquitic y Guadalupe Victoria. Bueno, ahorita, según por indicaciones del Departamento e indicaciones de la misma Secretaría, todas las escuelas que tienen maestro de apoyo o tienen niños integrados ya, son escuelas integradoras, entonces nosotros tenemos aquí nueve escuelas, quiere decir que tenemos nueve escuelas integradoras, independientemente si entraron o no al proyecto ya ahorita son escuelas integradoras, por el 


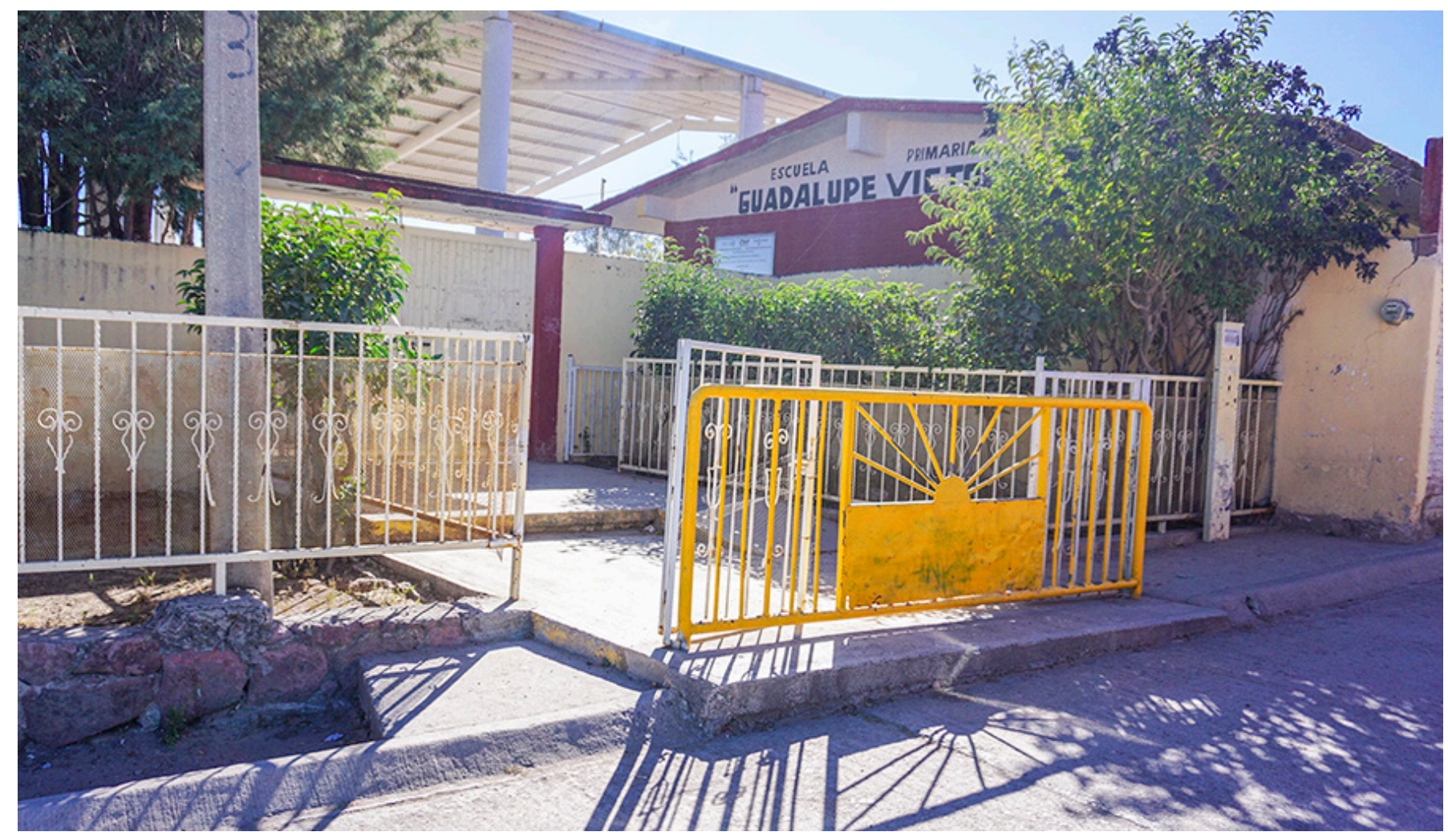

Figura 1. Escuela Primaria "Guadalupe Victoria".

simple hecho de ya tener al niño y nosotros pues ya tener el maestro especialista.

La directora piensa que no ha sido fácil el proceso de cambio de modalidad de "grupos Integrados" (GI) donde se atendía únicamente a los grupos de $1^{\circ}$ y $2^{\circ}$ a la modalidad de "grupos de apoyo" (GA), porque esta última implica atender a los seis grados de educación primaria e incluso de preescolar $y$, aunque no es el caso, en algunas USAER también se ofrece apoyo en secundaria. Como directora de USAER considera que su función es de mayor responsabilidad y alcance:
[...] ya con la comisión [como directora de unidad] ya el trato es con los directores, [...] con autoridades, presidentes municipales para hacer gestiones, DIF, este, ya otras situaciones y muchas actividades más que el Departamento [de Educación Especial] marca, hay muchos programas que educación especial tiene que cubrirlos, siempre en beneficio de los niños. $O$ sea, más trabajo porque aparte de que trabajas con los maestros, el equipo de apoyo, que son diez, quince más o menos elementos, también tienes que conocer los doscientos y veintitantos niños que atiende la USAER.

Con respecto al desempeño de docentes de apoyo y directivos comenta: 
Y hay, honestamente, también hay maestros de apoyo, como todo, hay maestros no tan muy buenos, como directores también hay directores muy buenos, otros no muy buenos [...] pero son situaciones que se van dando. La situación se va resolviendo, como se va presentando, cada una de las necesidades. Y bueno, también asesoría, reuniones para poder cambiar la modalidad, a lo que es grupos de apoyo; y le digo, estamos en proceso porque hay escuelas donde, yo pienso, que al maestro de apoyo lo ven como asistente, como si fuera practicante vamos; porque dicen, el maestro de apoyo es el que va a planear la clase; si planea clase, tiene que hacer algo de material, tiene que hacer todo, lo que dice la planeación, algún material muy específico, que es diferente a lo que a veces hacemos, cotidianamente, los maestros regulares...entonces se ve la diferencia, y en algunas escuelas yo si veo que lo están viendo como comodín, como practicante, como, porque que es el que va a venir a darme la clase, a lo mejor no una clase modelo, pero sí una clase como si fuera específica; y no es nada del otro mundo porque es el mismo plan y programas, libro del maestro, del alumno, son los mismos materiales que estamos trabajando nosotros. Desafortunadamente, no es así en todos los casos, [somos] algunos maestros, especialistas, que llegamos al salón de clase sin nada también...

La USAER 15 tuvo estadísticamente, durante el ciclo escolar 2004-2005, a la comunidad de Guadalupe Victoria con mayor índice de "discapacidad".
"Simplemente en el jardín de niños hay cuatro alumnos con discapacidad auditiva, discapacidad motriz y discapacidad intelectual" -comentó la directora-.

Durante el ciclo 2005-2006, en tercero de primaria se atendió a un niño de 9 años que asistía gracias a este programa. La evaluación psicopedagógica del alumno refiere que:

El niño pertenece a una familia "disfuncional" nuclear de cinco integrantes y es el primero de tres hijos. El padre no tiene escolaridad y es jornalero. La señora estudió hasta $5^{\circ}$ de primaria y se dedica al hogar. El padre rechaza y maltrata al niño y le reprocha a la madre la situación. Ella lo atiende y lo apoya. Es un niño delgado de tez morena, talla y peso acorde a su edad, de apariencia cuidadosa. Existe deterioro en sus piezas dentales. Hay espasticidad en sus manos, miembros inferiores flácidos. Su mirada es vivaz y comprende lo que se le dice más no puede hablar. Se le ha sugerido a la madre el uso de andadera, pero el niño no se acostumbra a ella por lo que prefiere arrastrarse para desplazarse. Se le ha diagnosticado discapacidad motora y de lenguaje oral (articulación). Se reconocen en el niño ciertas capacidades cognitivas y se le trabaja un cuaderno especial para las actividades de lenguaje.

Como puede observarse, la evaluación psicopedagógica, si bien pretende conocer las capacidades más que las limitaciones de los niños a partir de un enfoque interaccionista, contiene una terminología en la que subyace un 
modelo funcional que bloquea la posibilidad de obtener un conocimiento más cercano sobre las capacidades reales de los niños. Es evidente, por tanto, la necesidad de reflexionar acerca de lo que Skrtic (1996) y Franklin (1996) argumentan con respecto a que el enfoque empirista empleado en la educación especial desde sus inicios sólo ha sido superado parcialmente y sigue siendo un obstáculo en esta área.

Filidoro (2003) señala que los especialistas en educación especial no logran desprenderse de concepciones segregacionistas con diagnósticos como severos o moderados, ("los nombres del encierro" heredados del enfoque nosológico de la medicina y la psiquiatría). De esta forma, se sigue segregando al alumno "integrado" sin necesidad de pagar los costos de expulsarlo.

Por otro lado, la caracterización de la familia, como "disfuncional", parece remitir a una situación de gran desventaja que, confrontada con los relatos y testimonios de la madre, se interpreta de manera parcial y unilateral desde la escuela, desconociendo los momentos críticos por los que la familia ha atravesado y frente a los cuales la madre ha salido avante.

Con respecto al ingreso y permanencia del niño en la escuela primaria, la directora de la USAER comenta que al principio hubo cierta resistencia por parte del director y de algunos docentes. Sin embargo, el equipo de educación especial realizó los trámites necesarios argumentando el derecho que se tiene de recibir educación en el lugar que le corresponde al niño, independientemente de sus características y condiciones. La mayoría del personal de la escuela aún no ha cobrado conciencia de que es el único recurso con el que se cuenta en este medio o bien, no se considera responsable de atender a esta población. Sin embargo, algunos docentes, como el maestro de sexto grado, piensa que la integración es algo que siempre ha estado en el medio rural, que ahora hay más sensibilización hasta de los padres porque antes se avergonzaban y ahora ya no. Además, ahora hay especialistas que los apoyan.

Por su parte, la mamá del niño cuenta:

cuando lo llevaba a terapia a los cuatro años, me dijeron que ese niño necesitaba también meterlo al kínder. Fui a ver si me lo aceptaban y me dijeron que sí. Y sí lo trataron bien. Luego aquí lo vine y lo apunté, yo siento como no querían aquí los maestros. Una señora grande habló con el director y dijo: "No, este niño lo tienen que admitir, si no pierden su trabajo. $\mathrm{Si}$ aquí está su escuela; ella no tiene por qué ir al centro, [a] batallar a otra escuela..." porque los maestros de aquí dijeron que necesitaba la escuela especial para él.

La directora de USAER recuerda que, en un inicio, en el caso de este alumno:

Fue batallar con el director [que estaba] en aquél entonces, que porque no, no lo quería inscribir de entrada: "No, pues es que trae pañal y qué o quién lo va a cargar", y que no sé qué. Uno y mil obstáculos. 
Pero bueno, ya después de tanto de la trabajadora social, con el cuadernillo de normas de inscripción, no le podemos negar la entrada a nadie. $Y$, entonces, dice el director, en algún tiempo nos llegó a decir:

-Es que ustedes nomás quieren ir a buscar niños y aquí traerlos y dejarlos ¿̇y qué?

- No, está el maestro de apoyo.

- Y ustedes nada más vienen cada 15 días.

O sea, como que el maestro nos daba a entender que nosotros traíamos el problema y ahí se queda... ¿verdad? $Y$ ahí se refleja el trabajo del equipo de apoyo de sensibilizar a esta gente, tantos padres de familia, mismos alumnos, mismos compañeros, maestros regulares y especiales; después de tanto trabajo te queda esa satisfacción también. Como quieran y gusten lo fuimos llevando a la escuela...

Es así como los procesos de gestión, a través del servicio de educación especial, promueven el cumplimiento legal de los derechos y obligaciones en materia educativa. Aunque se observa la resistencia del director y de parte del personal, el acceso a los servicios educativos les brinda a los alumnos la oportunidad de ejercer su ciudadanía e iniciarse en una participación social activa.

La maestra de tercer grado considera como gran desventaja del medio rural el no poder contar con los recursos de la ciudad, por lo que: "es un cambio muy drástico, muy rotundo el venir de una ciudad a trabajar en una comunidad". Y agrega:

Como en esta comunidad, Guadalupe Victoria, las madres, en general, son solteras y trabajan como empleadas domésticas o de servicios en la capital, por lo que los niños se quedan solos, estando los hermanos mayores al cuidado de sus hermanos pequeños, casi todo el día. Aquí, la realidad es que en la comunidad se ven muchos casos de niños con problemas, demasiados casos; y principalmente, vemos desde el principio que todo redunda en la cuestión familiar, porque ora [sic] sí que desde los padres de familia, o sea desde los señores grandes, ya personas adultas, muchas de ellas no tienen la primaria, no saben leer y escribir, entonces mandan a los niños a la escuela porque tienen que mandarlos, pero no es una cuestión que digas por necesidad, porque salgan adelante, porque sean hombres de provecho, sino porque tienen nada más que mandarlos.

Ella atribuye como problemática grave el analfabetismo de los padres, que parece traducirlo en desinterés por la escolaridad de sus hijos. Una situación recurrente en esta última es que los niños llegan a $3^{\circ} \circ 4^{\circ}$ grado sin saber leer y escribir. Al parecer, una estrategia que utiliza es trabajar el lado afectivo en el aprendizaje, por lo que ha tenido algunas satisfacciones al "rescatar" algunos "casos perdidos" y lo describe así: 
Yo recuerdo a otro alumno, tenía el problema de que era el más chico de una familia mucho muy grande, ese niño también yo lo estuve tratando; por lo regular, le busco más por el lado afectivo, porque siempre trato de que ellos se sientan con la confianza de platicarme, de hablarme, de decirme sus problemas. Ese niño estaba en tercero y no leía nada [...] poco a poco fui yo, [...] tomándolo [...] casi, casi a mi cargo personal y pues salió adelante el muchacho y ahorita es un señor ya hecho y derecho. En cuarto año también tuve un niño, también con las mismas características, nada de lectura; su mamá murió y se quedó con el papá, pero su papá tomaba mucho y despertaba al niño en la madrugada para que fuera a comprarle cerveza. El niño era tímido, ese niño no hablaba, no se relacionaba con los otros niños, siempre tenía miedo, entonces había una señora que lo recogió, o sea, como quien dice lo adoptó. $Y$ entre la señora, la maestra de apoyo y yo, las tres, tratamos de sacar adelante al niño y ahora él es un hombre de trabajo, estudia y está muy bien.

Cuando comenzó el ciclo escolar la maestra se angustió mucho, incluso hasta lloraba, porque no sabía cómo atender al niño en su salón, a pesar de la experiencia y la preparación que tiene, porque "es muy difícil trabajar con él que con todo el grupo y con la presión de tener que ver los contenidos del grado." Por eso, considera que el trabajo individualizado y la orientación que recibe del equipo y del maestro de apoyo son importantes. Ella comenta:
Ahorita tengo como 8 niños con el problema de lectoescritura, tengo un niño con discapacidad [refiriéndose a este alumno] y que, sinceramente, ese niño es algo especial y no digo especial por su discapacidad, digo especial, en todo el sentido de la palabra, porque es un niño excepcional, me ha dejado [...], ahora sí que hasta se me quiebra la voz porque es un niño inteligentísimo, o sea, es un niño despierto.

Es una experiencia... yo en este momento estoy viviendo una situación, para mí un tanto difícil, soy sincera, porque yo quisiera tener tanto los conocimientos como la oportunidad para poder ayudarlo, para poder sacarlo adelante; para mí, es casi una necesidad, desgraciadamente, yo quisiera hacerlo, pero tengo al grupo también a mi cargo y tengo que atender al grupo. Siempre estoy: "Espérate mi'jito, ahorita te atiendo. Espérate tantito mijo". Le pongo trabajo y tengo que estar con él para que haga los trabajos y la verdad ahora que sí, sinceramente, ojalá que me puedan ayudar.

La maestra de grupo regular, a pesar de no saber cómo dirigir el proceso de enseñanza-aprendizaje con este alumno y de la angustia que esto le produce, al establecer una relación basada en el reconocimiento de sus capacidades está posibilitando y favoreciendo su avance. Además, es importante observar cómo el aspecto emocional es un factor decisivo que incide en el mismo. 
Cabe mencionar que, por otro lado, es una práctica recurrente que se le pida al maestro de apoyo que "cubra" grupos cuando no está el maestro responsable. Por ejemplo, al inicio del ciclo escolar, el maestro de apoyo estaba trabajando con el grupo de $2^{\circ}$ grado porque aún no llegaba a la escuela el maestro que los debería atender. El maestro de apoyo comenta al respecto que "de esta forma puede detectar qué niños tienen problemas y que van muy atrasados, pero que esta situación no le permite dar el apoyo como se debe". Al respecto, si bien la supervisora de educación especial, al inicio del ciclo escolar, hizo la sugerencia de que evitara cubrir grupos porque de esta manera no podía realizar el apoyo adecuadamente, él piensa que tiene que colaborar con la escuela si no pueden cerrarle las puertas.

Cuando el equipo de apoyo de educación especial va a la escuela realizan un trabajo individualizado que les ha permitido conocer las posibilidades y limitaciones del niño, quien ha recibido atención especial desde el primer año por lo que llegó arrastrándose al salón de apoyo. En la primera sesión, traía su libreta y un lápiz bajo el brazo. La maestra de comunicación y lenguaje le enseñó un globo y le dice que si quería trabajar con ella. Él afirmó con la cabeza y se veía entusiasmado.

Con este alumno el problema es la mamá; que no hay disciplina ni respeto en la casa. Hablamos con ella y como si nada. Ahora, la maestra, cómo es posible que chille, que diga que ella chilla porque no sabe cómo tratar al niño. No creo que no haya tenido experiencia con un primer grado, que no sepa qué actividades le puede poner al niño. Ella le está pidiendo al maestro de apoyo actividades para trabajar con el niño. Tiene preparación, tiene experiencia. Ya ha trabajado en $1^{\circ}$ y $2^{\circ}$, a poco no puede. Lo usan como justificación el que tienen al especialista.

Nuevamente se observa como algo recurrente el empleo, en el personal de educación especial, de un criterio que descalifica el desempeño de los padres y el docente de escuela regular en la atención dada al niño, sin considerar las condiciones sociales y ambientales en las que se desenvuelven estos sujetos. El conocimiento que pueden tener como equipo del niño y sus capacidades, así como la atención específica y el trabajo individual que realizan podría ser compartido en términos de colaboración y reconocimiento de los otros sujetos. En ese sentido, esta es una debilidad encontrada en el personal de educación especial. Lo que podría cuestionarse en este aspecto es la forma como se establecen vínculos y relaciones con los padres durante las entrevistas que se limitan a considerar que su obligación es apoyar el aprendizaje de los niños y darle los materiales necesarios para ello. Cuando la escolaridad es mínima y se vive en condiciones de subsistencia lo que cobra relevancia es el valor y el esfuerzo que se necesita para enfrentar las adversidades que se presentan en el medio rural. 
El psicólogo comentó también que en la casa del niño habían acondicionado unas barras para que se apoyara para caminar, pero que las quitaron el día que tuvieron una fiesta y necesitaban espacio para el baile. Cuando el niño llegó le preguntaron que dónde estaban las barras con las que caminaba y él dijo: "no" con la cabeza. El psicólogo le preguntó: " ¿Por qué las quitaron?" Y el niño brincó y se movió como si estuviera bailando. "Ah! Las quitaron para el baile" dijo el psicólogo, y él sonrió.

Así, el equipo de educación especial podría considerar y comprender, más que juzgar, la angustia de la maestra ante las condiciones del aula y del trabajo docente porque, cuando se cuenta con el servicio de educación especial, se espera que el maestro de apoyo cumpla con esta función de asesoría y acompañamiento al docente de escuela regular, no obstante, en este caso, el maestro de apoyo, quien tenía trece años en educación especial, sólo contaba con normal básica por lo que, ante situaciones de atención específica, solicitaba capacitación y ayuda a la directora de USAER durante las visitas quincenales.

En este caso, durante los dos primeros grados escolares, el niño estuvo a cargo de otro docente de apoyo que se cambió de lugar, por lo que recurrió en un inicio a la directora y al equipo de apoyo para que también le asesoraran en cuanto a la forma de evaluarlo pues éste no tenía lenguaje oral: "él sólo dice papá y se da a entender con gestos, pero nada más", según comentaba el maestro de apoyo.
En una de las primeras visitas del equipo de apoyo a la escuela regular, realizaron una junta inicial con las madres de familia, en la cual se hicieron comentarios de que: "Los maestros los dejan y se quedan con los que saben en el grupo". De esta manera, una evidencia sentida por ellas es cómo los maestros de grupo regular van dejando de atender a los alumnos que se van rezagando y sólo se dedican con los que siguen su ritmo de trabajo.

Posteriormente, el equipo, de manera interdisciplinaria, analizó el caso. El psicólogo argumentó que era necesario un plan sistemático e integral que permitiera coordinar las acciones del equipo para la elaboración de un programa específico de intervención, algo que al parecer no se había logrado hasta ahora:

- Bueno, ya conocemos el caso, aquí lo que hay que hacer es fijar una meta. Hacer algo concreto y aterrizar como equipo para ofrecerle alternativas al maestro de apoyo. ¿Qué se espera del alumno para este ciclo escolar? Jerarquizar sus necesidades -indicó el psicólogo y a continuación intervino la directora.

- Yo se los dije a las mamás en la junta hace rato. Lo que queremos es que los alumnos aprendan a leer y escribir, pero si no podemos lograrlo hay que darles otras metas.

- Yo creo que hay que ver cuál es el problema en el salón: aprovechar los formatos y los análisis de tareas que vimos en los Talleres Generales de Actualización. Hacer un programa escrito. Luego andamos hasta final del año llenando 
los formatos porque no registramos todo lo que hicimos con los niños.

-Sí te entiendo - dijo la directora- Ya sabemos qué necesita, o mejor dicho cuál es su mayor dificultad y hay que poner manos a la obra. - Por lo regular así lo hacemos, sugerimos en las escuelas, damos sugerencias, pero dónde lo escribimos, dónde demostramos lo que hacemos. Hablamos y hablamos y se queda en el viento. Hay que ver qué se puede hacer, qué no se puede hacer -dijo el psicólogo.

- En la rehabilitación física yo no me atrevo a intervenir porque no soy especialista en esa área. - Pero sí es una prioridad del niño...

Es así como, al parecer, la USAER se encuentra limitada para poder intervenir de manera más adecuada.

A mediados del año escolar, la maestra de grupo, por su parte, recuperaba algunas situaciones que habían ido cambiando la forma de concebir el proceso de aprendizaje del niño, que se describen de la siguiente manera:

Ayer, por ejemplo, vino una señorita a hablar en el grupo de los valores. Él estuvo atento a lo que estuvo la señorita hablando, a lo que yo les había hablado sobre la importancia de los valores... llega la mamá ahorita en la mañana y me dice:

-Oiga maestra, ¿̇a mi hijo le dieron hojas para el cuento?

-Sí, señora, mire porque aquí su hijo es igual que todos, para mí él aquí es lo mismo que cual- quier niño.

- Pos sí -dice - ahí está que todo el día andaba con su hoja para arriba y para abajo y anoche ahí está que le escribiera el cuento.

De veras se me hizo un nudo en la garganta, de ver la responsabilidad que tiene el niño para cumplir con lo que se le está pidiendo.

La maestra agregó:

El día de ayer estábamos viendo lo de unidad, decena y centena. Entonces yo le estaba preguntando al niño: "Diez unidades żqué es lo que hace?" Inmediatamente él pone sus dedos y me dice que son diez. Le pregunto: " $Y$ una decena ¿¿Cuántas unidades son?" Y me pone sus dedos y dice que son diez.

En la cotidianeidad de la vida escolar, la maestra fue comenzando a darse cuenta y reconocer las posibilidades del niño, al platicar eventos como el siguiente:

El otro día me sorprendió que estuviera yo explicando el valor posicional y varios niños no me entendían. Entonces él alzaba la mano constantemente hasta que le dije: "Bueno, a ver, pasa tú". Pasó... y como pudo, con garabatos y todo, ubicaba muy bien el lugar de las unidades, las decenas y las centenas. Yo le decía: "5 decenas", y colocaba su mano en el lugar de las decenas, igual con las centenas y unidades. Me quedé sorprendida. Por eso, le pido al maestro de apoyo que me indique 
qué actividades ponerle, qué materiales usar. El maestro de apoyo sí me ha ayudado. Sí, claro que sí. Yo le digo que no quiero que se lo lleve toda la mañana, pero también le ayuda el apoyo individual. El año pasado el maestro sí trabajaba con él y le daba actividades de lectoescritura. Lo que hago es delinearle las letras para que las calque y escriba palabras que identifica bien. Las puede relacionar cuando yo le digo cómo dicen. A veces yo platico con mis compañeras y me dicen que no sea así, que no me involucre, para no tener problemas con los padres. Pero, no puedo, cómo voy a hacer como que no me doy cuenta, que no pasa nada.

En la segunda semana de febrero, el niño fue a la biblioteca y una maestra le leyó una fábula de Esopo. En la carrera de la liebre y la tortuga, cuando le preguntó quién iba a ganar, señaló con su dedito que la liebre; y se sorprendió cuando la maestra leyó que quien ganó fue la tortuga y no podía dar crédito a las ilustraciones. Cuando escuchó que su grupo salía a ensayar el juramento, rápidamente se alistó para participar. Aunque no podía ir en la fila al paso de los demás, con su andadera ensayaba el juramento frente al asta bandera. La maestra comentó que pediría una silla de ruedas para que alguien lo llevara ese día. "Tenemos mucho trabajo esta semana... mañana es el Himno, pasado el concurso de escoltas y el viernes el juramento", concluyó emocionada.

En el mes de marzo, se hizo una visita a la casa del alumno. Su mamá comenta que la abuelita paterna es "muy fea con él porque no lo quiere". Es una casa pequeña pero bonita. Con un patiecito de cemento y un jardincito con macetas y flores. Un cuarto cerrado es la recámara de los abuelitos y la otra, su cocina. Ella platica: "Hay un niño de aquel lado... yo pienso que tiene como diez años, pero nunca lo han llevado a la escuela, ni lo sacan. Lo tienen encerrado porque también está enfermito".

La dualidad: aceptación/rechazo se ve reflejada en los abuelos paternos, ya que, según la madre, "su abuelita no lo trataba igual, a mis otros hijos los acariciaba, pero a él no; por eso el niño no la quiere".

El estadio del espejo y la mirada del otro: que, de acuerdo con la teoría del psicoanálisis lacaniano, se consideran momentos decisivos durante los cuales el niño se "reconoce" a sí mismo en la imagen del espejo o en un otro semejante y próximo que le representa. "El estadio del espejo se describe como formador de función del yo" y es el momento en el cual el infante se encuentra por vez primera capacitado para percibirse, o más exactamente, percibir su imagen corporal. Esto sucede normalmente entre los seis y los 18 meses.

Lacan (1980) argumenta que la construcción que hace del yo es imaginaria, es decir, hay una imagen cargada de sentido que viene del otro. El yo se apropia de ella y la interioriza. Por tanto, la imagen con la que se identifica el niño no es la reflejada en el espejo. La imagen se relaciona con la mirada del otro, a esto se le denomina: narcisismo primario. 
Baste para ello comprender el estadio del espejo como una identificación en el sentido pleno que el análisis da a este término: a saber, la transformación producida en el sujeto cuando asume una imagen, cuya predestinación a este efecto de fase está suficientemente indicada por el uso, en la teoría, del término antiguo imago [...] cuya función es establecer una relación del organismo con su realidad. (Lacan, 2007, pp. 87-89)

En el proceso de constitución del yo, ha sido "la mirada del abuelo" la que ha permitido una identidad en el niño sobre la capacidad de aprender a pesar de las limitaciones físicas y lingüísticas. La mamá dice:

Las gentes [sic] a lo mejor se les hacía muy fácil decir que ese niño no iba a aprender. No, pos mi suegro siempre ha dicho que ese niño se mira que iba a salir más listo que los otros - luego destaca-Su abuelito es diferente. Él dice que el niño es más listo que los otros.

La madre refiere una fuerte problemática familiar con respecto a la situación de su esposo al haber tenido una familia antes de casarse con ella; así como a su situación legal, al haber estado preso. Esto afecta el aspecto económico y emocional de la familia. Sin embargo, ella trata de atender a sus hijos dentro de sus posibilidades. Ella afirma: "La gente de aquí del mismo rancho me dio la mano, que por mi niño enfermo yo no podía ir a trabajar para darles de comer".

El nacimiento del niño ha sido un momento crítico en su vida, pues fue una situación de vida o muerte. Al recordar este evento la madre comenta:

Mi niño nació malito y anduve con él en el hospital hasta ahorita ando todavía...pos como era el primero, pos yo no sabía, ya iba para los diez meses y no me daban dolores ni nada... él nació todo moradito. Él duró como quince días internado y que estaba luchando entre la vida y la muerte, estaba luchando para vivir... Todavía no puede comer, no puede mascar él.

Lo anterior, lleva a asociar las situaciones de riesgo con enfermedad, así como a reforzar la creencia social de que los niños con estas características no pueden aprender, por tal motivo los tienen encerrados en la casa; sin embargo, esta idea se está desvaneciendo ante la sorpresa de docentes, alumnos y padres de familia que observan y reconocen la capacidad intelectual del niño que incluso sobresale en el grupo. Al respecto, la mamá señala:

Una señora de para allá, de arriba, su niño sí está malito. Tiene unos 8 o 9 años. No lo trae porque le da vergüenza. Yo digo que sí le ha perjudicado no venir a la escuela. No pos, mi niño, se imagina si lo hubiera dejado ahí, el niño no estuviera como está ahorita $y$, poco a poco, ahí va aprendiendo. 
Lo que parece más significativo es el gusto y deseo del niño por asistir a la escuela y por aprender, que no sólo la madre percibe directamente, sino los que lo tratan de manera más cercana; como se observa en el siguiente comentario de la madre:

aunque al principio pos nada más hacía rayas... a él siempre le ha gustado venir a la escuela, se levanta bien temprano que ya se quiere ir, desde que se va a acostar está muy emocionado, que se va a acostar porque ya va a amanecer y se va a venir a la escuela a escribir.

La "identidad social" (Goffman, 2003) atribuida por la comunidad está siendo modificada lentamente ante las capacidades y atributos que el niño está demostrando tener en la familia y en la escuela.

En el mes de mayo, período de evaluación final en las escuelas, en entrevista con la directora de la USAER, comentó los avances que en las últimas visitas han observado ella y su equipo.

[...] ayer que estuvimos en Guadalupe Victoria, yo vi muchos avances, muchos avances. Ahí es cuando te llega a ti, iqué bueno! ¿No? A lo mejor no ves que ande corriendo, ya sepa leer y con todos y cómo dice porque sabemos que no habla, pero sí sabe, te da muchas muestras, te da características de que sabe. Porque con la maestra de Comunicación y lenguaje, dice: "Vamos a evaluar al niño". Y con matemáticas, por ejemplo, lo básico lo tiene muy bien, figuras geométricas, los colores, los números, o sea, no que los diga, no, pero sabe, sabe él cómo se llama el número, la cantidad la sabe representar muy bien. Porque la maestra le pegaba pedacitos, así, hasta el diez. Coloca piedritas lo hizo muy bien, hasta el 19, hasta el 20. ¡Qué padre! Si ha servido de algo, a lo mejor no mucho, pero lo que él ha hecho ha sido mucho, para mí y para los demás, en tercero de primaria y apenas hacer eso, pero es bastante por cómo estaba; y ahí te sientes a gusto o bien.

La madre tiene una expectativa positiva con respecto a su hijo: que haga una carrera profesional; por eso sostiene una lucha diaria por mantener a su hijo en la escuela, dentro de sus posibilidades y limitaciones no ha dejado de llevarlo porque, como ella dice:

Que termine su primaria, luego la secundaria y la prepa. Que estudie algo como de licenciado, digo, porque yo he visto muchos casos así, están enfermitos, chuequitos, pero son licenciados y arreglan... Sí me han tocado cosas difíciles. Nomás que lo traigo y lo llevo [cargado]. Pos, antes dicen que no estaban estos niños en la escuela y ya son otros tiempos. 


\section{Corte Primero: El conflicto no resuelto}

La comunidad de Corte Primero se encuentra a casi $40 \mathrm{~km}$ de la ciudad capital del estado de San Luis Potosí, sobre la carretera que va al municipio de Ahualulco, con una desviación de $10 \mathrm{~km}$ aproximadamente hacia el este.

Corte Primero es de las pocas comunidades que todavía se dedica a la agricultura como actividad económica principal. También ha jugado un papel importante en la política del municipio. Es una localidad de gran extensión territorial y de población al contar con cerca de 2,000 habitantes; 513 son niños y jóvenes entre 6 y 14 años (casi una cuarta parte), de los cuales $73(14.23 \%)$ no asisten a la escuela. Se reportan, oficialmente, 42 sujetos al proceso de inclusión, es, por tanto, la tercera comunidad con el mayor índice de población sujeta al proceso de inclusión, precedida tan sólo por San Marcos Carmona y El Palmar.

La comunidad cuenta con los servicios básicos de agua potable y luz eléctrica. Hay además un centro de salud comunitario. Durante el tiempo de trabajo de campo (2005-2006) se estaba arreglando el sistema de drenaje. Hay casas con grandes solares, algunas con bardas, otras tienen hornos de barro al aire libre para elaborar pan y gorditas. La escuela secundaria técnica está sobre la entrada principal a la comunidad.

El autobús se para en la plaza principal, con la iglesia al frente (figura 2). Una señora de la comunidad comenta que: "Ya no se siembra como antes..." (ante la escasez de agua), "por

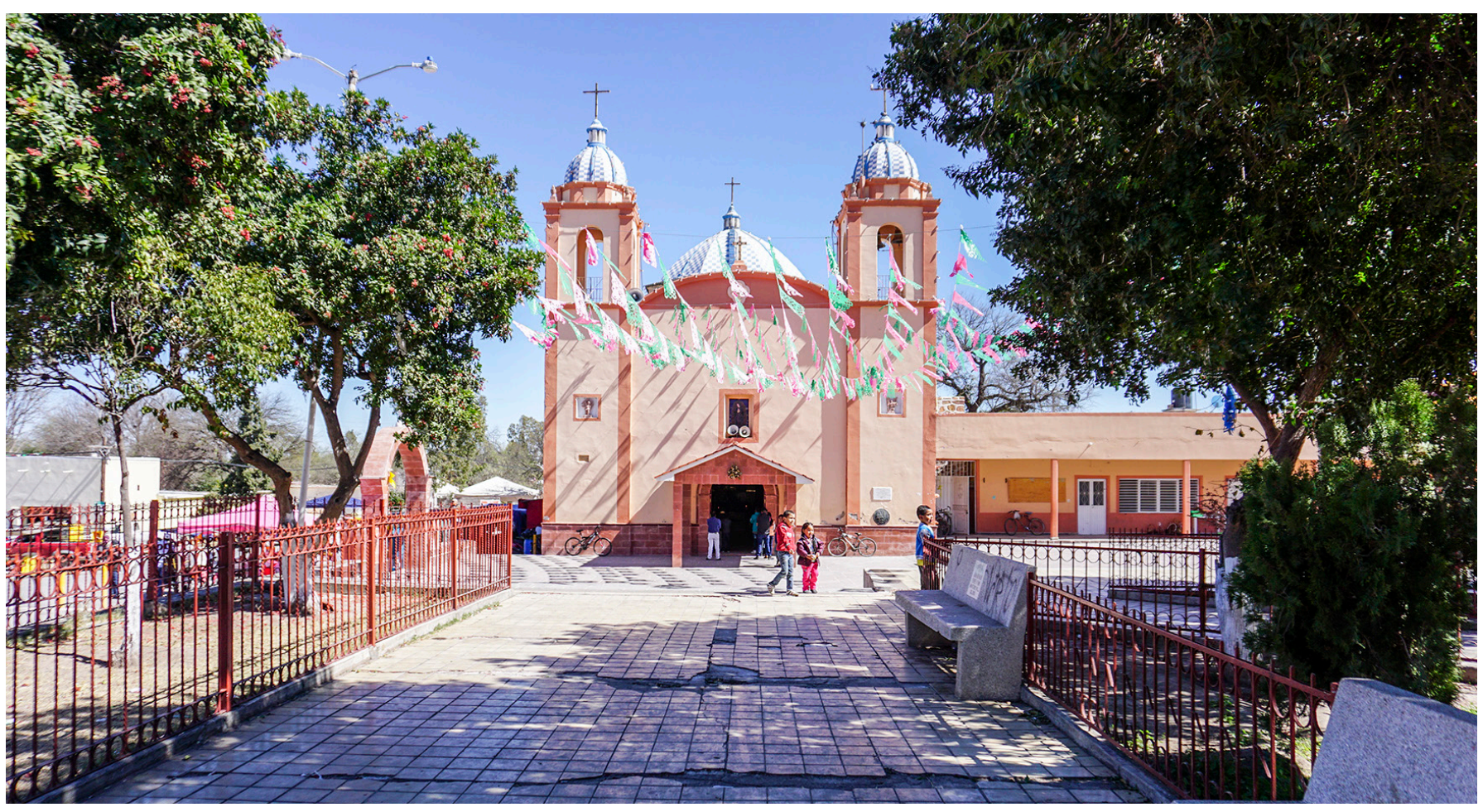

Figura 2. Parroquia Nuestra Señora de Guadalupe. 
eso la gente mejor se va pa'l otro lado". Dos cuadras hacia el este, sobre una calle amplia que también está obstruida por los trabajos de excavación, se encuentran el jardín de niños y al lado la escuela primaria "Damián Carmona".

La escuela primaria es muy grande en extensión (900 $\mathrm{m}^{2}$ aproximadamente). Se encuentra sobre relieve regular, rodeada por una barda de piedra y herrería blanca (figura 3). Se observa a la entrada un área de tierra con algunas plantas y flores, seguida de una construcción antigua que corresponde a la primera escuela, con dos salones grandes de adobe $y$ puertas de madera $y$, a la mitad del terreno, un pequeño cuarto que al parecer fue la "Casa del Maestro" y que ahora sirve como desayunador para los maestros a la hora del receso. Otra área está formada por edificios paralelos más modernos, construidos de ladrillo, amplios ventanales y puertas metálicas. Hay una cancha con piso de cemento que sirve de explanada o plaza cívica, con bancas de cemento alrededor y con una asta bandera inclinada en la parte lateral izquierda que corre el peligro de caerse. Sobre ese mismo lado hay un estrado con una pared de fondo construida con piedra que al parecer ya no se usa. Del lado opuesto están los baños, amplios y con un espacio compartido para hombres y mujeres para lavarse las manos.

A la hora del receso los niños juegan y otros corren hacia el estanquillo de la cooperativa, en donde venden duritos, frituras y dulces. Las mamás acostumbran a llevar lonches a los

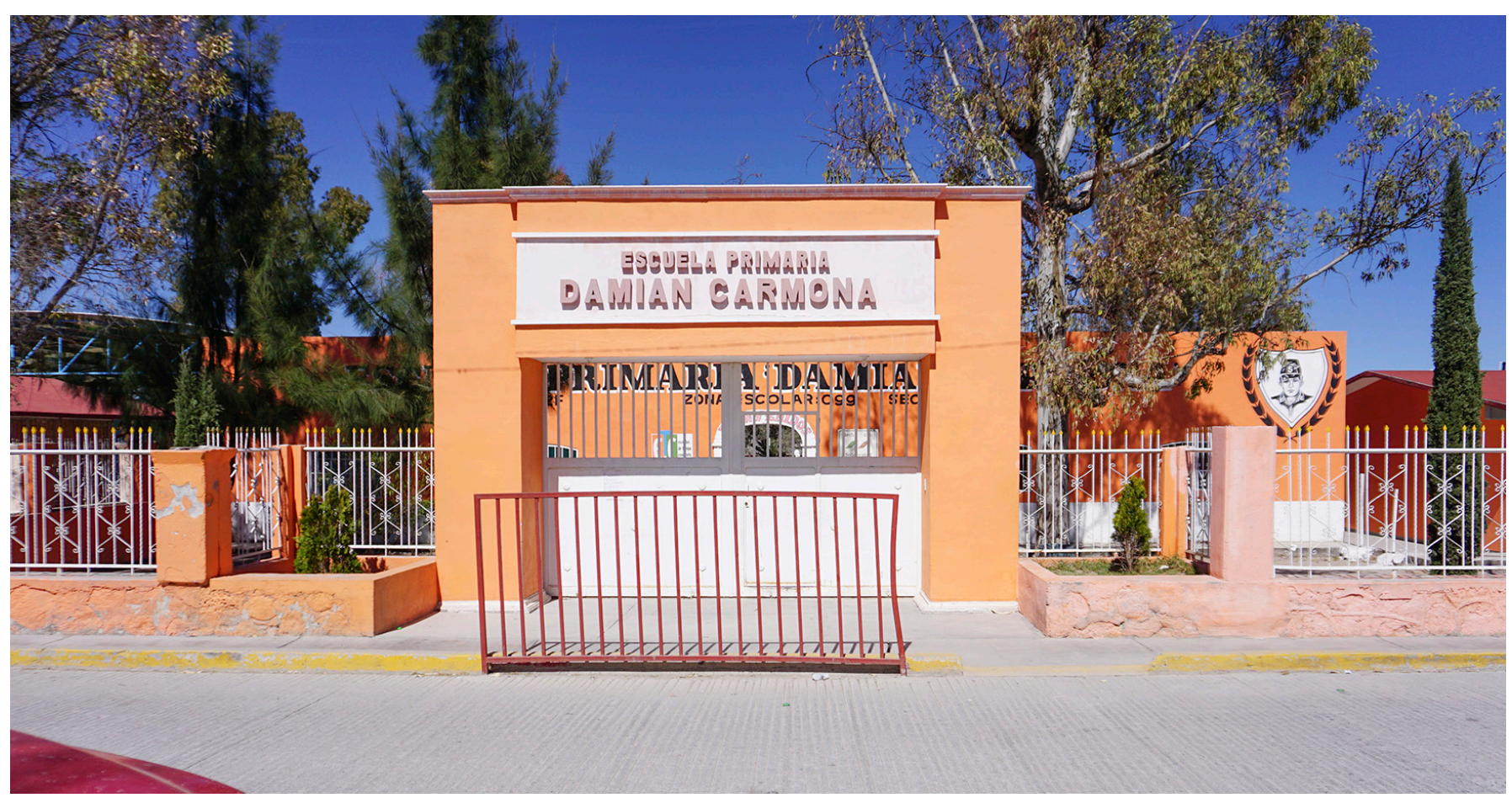

Figura 3. Escuela Primaria "Damián Carmona". 
hijos, ya sea a través del barandal de entrada o dentro de la escuela. Hay algunos perros que deambulan en el lugar. Los niños usan uniformes y la mayoría andan limpios, aunque es notorio que también hay una minoría que se ve descuidada en su aseo personal.

En el ciclo escolar 2005-2006, se tuvieron estadísticamente: 174 padres de familia, 273 alumnos, 18 integrantes del personal de la escuela, 12 maestros y 8 "alumnos integrados".

La maestra de apoyo describe a las mamás y los papás de los alumnos que conforman su grupo, así como a sus maestros de grupo regular, de la siguiente manera:

Un alumno tiene a los dos papás y la maestra sí apoya. Otro tiene a su papá, pero él está trabajando en E.U. Su maestra no lo apoya y no tiene comunicación con ella. Hay dos niñas que son hermanas, pero la primera sí vive con la mamá y la segunda vive con una hermana mayor que está casada. Tania falta mucho o llega tarde, porque al parecer le ayuda a cuidar a los sobrinos. Otras dos son primas. La mamá de otra niña es más abierta y platica más. No conoce a su maestro porque acaba de llegar a la escuela y no sabe cómo trabaja. Otro alumno es huérfano de mamá; vive con el papá, con dos hermanos enfermos, una hermana de prepa y con su abuelita enferma. En la escuela hay muchos huérfanos y muchas madres solteras, por lo que se mandan a los hijos a la escuela, pero no hay compromiso.
Se observa en el discurso de la maestra de apoyo una experiencia de rechazo en su relación con algunos docentes de la escuela regular y la manifestación de un sujeto negado que manifiesta su situación de crisis como sujeto.

El sujeto docente (en la educación especial), empeñado en su función de educar ese "resto" en los sujetos objeto de su tarea, quedaba atrapado en esa misma parcelación del sujeto humano... Una alumna de doctorado expresaba así esta realidad: "Los enseñantes en educación especial no sólo estamos excluidos, marginados dentro de la educación, sino que no existimos, estamos negados"... Para llegar a ser tal sujeto, necesita enfrentarse con la realidad, reflexionar sobre su experiencia y crear criterio... conjuntamente con quienes viven la experiencia educativa, en un colectivo más amplio... para una conversión que quizás suponga, en definitiva, una transgresión. (Pérez de Lara, 1998, p. 218)

A mediados de septiembre, el director de la comunidad de Corte Primero tuvo la junta con los padres de familia. Como la comunidad está dividida en cinco sectores, tienen a un representante por cada uno para que forme parte de la sociedad de padres de familia. El director planteó las necesidades de la escuela para que fijaran de común acuerdo la cuota de inscripción. La gente participa poco, aunque sí propone a los que consideran que pueden sacar adelante el trabajo. Lo que apremia es un sonido y la compostura de los baños. La cuota 
quedó en $\$ 120.00$ para sacar, al menos, esas dos necesidades, ya luego los consultarán para otra reunión.

En el recreo, una señora que vende gorditas y taquitos comentó que en el grupo de apoyo se atendía a "los niños más atrasados" y que antes no había tanta escuela. Que sólo había hasta $4^{\circ}$ grado. Sólo había dos o tres salones y eran de "caliche" (un material parecido al adobe). Ella era de la comunidad vecina de Corte Segundo, pero se casó con uno de aquí y se vino a vivir para acá.

La maestra de apoyo comentó en la primera entrevista que, socialmente, hay rivalidades y rencillas entre algunos sectores que se reflejan en la escuela al rechazar a algunas familias, principalmente a las que presentan mayor desventaja cultural y económica. Ese es el caso de una alumna, sus hermanos y sus primas. Los niños de la escuela los molestan diciéndoles: "guásaras". Sin tener idea de lo que significa, ellas salen a la defensiva, respondiendo de manera verbal, e incluso con golpes.

En el salón, la niña se sienta con su prima en la última banca. Al parecer, cuando sus compañeros le han dado queja al maestro de grupo sobre ella o su prima, él les dice que no hagan caso, que "esas niñas están locas". Por eso, se ha llamado esta situación permanente, "el caso del conflicto no resuelto" o del "eterno conflicto", en el que algunos docentes la agravan, mientras otros intentan ser mediadores $y$ conciliadores de esta. En ese sentido, Romano (2006) argumenta:
La pobreza y la exclusión cada día se constituyen en el principal texto escolar y la tarea docente se circunscribe y limita, en muchas ocasiones, a la realidad del aula en la escuela... La violencia escolar como significante adquiere autonomía propia y se la trata por fuera de la violencia estructural que provoca, en centenares de miles de niños, adolescentes y jóvenes y sus respectivos grupos familiares, la privación más absoluta de aquello mínimo e indispensable para una vida digna. (pp. 107-108)

Frye (1996) menciona que, históricamente, Corte Primero es una de las comunidades que más participó en el movimiento armado de la revolución por lo que son considerados como muy combativos y aguerridos. Esta situación de conflicto se hace presente, permeada probablemente por aspectos ideológicos y políticos.

Corte, una extensa comunidad del límite noreste de municipio que colinda con la gran Hacienda de "La Parada" ha estado también atrapada en la cuestión de la rivalidad territorial, por al menos los últimos doscientos años, por razones geográficas y económicas más que administrativas. La localización de Corte sobre el borde entre la cabecera municipal y la hacienda hace que su relación con ésta última sea una economía urgente y una comunidad importante, ya sea proveyendo recursos con mano de obra y producción, defendiendo la tierra local del abuso o invasión del gran estado o, últimamente, tomando la tierra en la lucha por la reforma agraria. La larga tensión centenaria 
con la hacienda impulsó o convirtió a la gente de Corte en políticos municipales y regionales más que ninguna otra comunidad en Mexquitic. Más agraristas de Corte que de ninguna otra comunidad lucharon en la revolución, y en las décadas posteriores a 1910 Corte ha producido más presidentes municipales que ninguna otra comunidad en este siglo -al menos una docena de ellos-. Este movimiento político ha conducido también a profundos conflictos dentro de la misma comunidad, incluyendo una rivalidad mortal entre los barrios vecinos de Corte Primero y Corte Segundo (Frye, 1996, p. 13). El autor concluye que es una comunidad digna de ser estudiada por su fraccionalismo y su relación entre Mexquitic y La Parada.

En el ciclo escolar 2005-2006, la alumna tenía 12 años. Cursaba $3^{\circ}$ de primaria. Era repetidora de $1^{\circ}$ y $2^{\circ}$ grado al no lograr la adquisición de la lectoescritura. Recibía apoyo por parte de educación especial y pertenecía al programa de integración educativa. Es una niña de estatura y complexión regular acordes a su edad, tez morena clara y pelo ondulado café claro. A pesar de estar casi siempre a la defensiva, es cariñosa y sonríe con frecuencia.

En su evaluación psicopedagógica se caracterizaba como "una alumna con un severo problema cognitivo, emocional y social". Se le atribuía, además: "un desarrollo motriz deficiente: mala coordinación óculo-manual, fina y gruesa". En cuanto a lo cognitivo, se señalaba que no había ningún avance. Su vocabulario era reducido, mal empleado y grotesco. Su au- toestima era baja, no ponía nada de su parte, no había interés por aprender ni seguir instrucciones aún en el juego. Era muy difícil trabajar con ella ya que se distraía fácilmente y en el grupo no lograba integrarse por la actitud agresiva que mostraba. El conjunto de valoraciones justificaba que a su edad no hubiera adquirido la lectoescritura y el cálculo elemental. El problema se ubicaba de esta manera en la niña y no en el tipo de relaciones que se establecían en la escuela y en la comunidad.

La familia estaba caracterizada por la escuela como "disfuncional nuclear", de "aparente" preocupación, pero sin el apoyo de los padres. El nivel sociocultural era valorado como "deficiente" pues los padres no referían escolaridad. Se infería la condición "hereditaria" de la discapacidad que podría reforzar la idea de que era un problema congénito familiar al argumentar que: "En la familia hay otra hija con dificultades severas en el aprendizaje y otra que desertó por diagnóstico de discapacidad".

La recomendación fue pasarla al programa de integración educativa y su canalización a todas las áreas de psicología, trabajo social y comunicación, ante el fracaso repetido con la etiqueta de "incapacidad" atribuido.

Este informe permite reflexionar en torno a lo que Foucault (2006) analiza, a través de su teoría del discurso, sobre el carácter normativo de las disciplinas científicas, como la psicología, la medicina y el derecho, que se traducen en prácticas discursivas ya que tienen el poder de excluir al individuo de la sociedad y de de- 
terminar las condiciones de su admisión a ella con miras a su "normalización". El saber del profesional de la educación especial es ejercido sin mayor cuestionamiento con respecto a su valor de verdad y a las condiciones históricas y epistemológicas en las que es producido. Las prácticas que se constituyen como necesarias y normales pueden ser juzgadas con una mayor carga de sinrazón o, a la manera de Foucault, irrisorias.

La mamá se presentó en una ocasión al grupo de apoyo después de haber tenido junta en el grupo regular de la niña. Llegó muy molesta y le comentó a la maestra de apoyo que el maestro de grupo regular le había dado puras quejas de ella, que no trabajaba, que nada más se la pasaba jugando y que distraía a los demás. Que no quería leer y no traía las tareas. La maestra de apoyo comentó que tenía que hablar con él pues iban dos veces que le decían que hostigaba a los niños y les llamaba la atención equivocadamente. Sin embargo, una vez que la maestra de apoyo quiso aclarar la situación, el maestro negó todo y ella sintió que quien había quedado en ridículo había sido ella, por lo que a veces prefería mejor ya no intervenir.

La niña y algunos de sus familiares (primos y hermanos), que aún estaban en la escuela primaria, ante el rechazo de algunos compañeros y docentes respondían con ofensas verbales y agresiones físicas constantemente.

La maestra de apoyo se había convertido en una mediadora de la situación. En una entre- vista posterior comentó que hubo un problema fuerte con ellas a principios del ciclo escolar. A la salida, la niña y sus primas "agarraron" a la hermana de un compañero. La amenazaron en el recreo diciéndole que a la salida la esperaban. Los maestros dicen que desde el recreo ya andaban con problemas porque una de ellas se estaba juntando mucho con la hermana del niño y que no debería hacerlo.

Es esta una manera de objetivar el tipo de violencia simbólica, aparentemente sutil, en la que se envuelve la situación escolar y social descrita.

Ante la amenaza de las distintas formas de racionalidad y los dispositivos que actúan y se emplean, tanto en el sistema penitenciario como en el hospitalario y hasta en el sistema escolar, la alteridad diferenciada y las prácticas que de ella se desprenden han adoptado diversas formas en las distintas condiciones históricas en la cultura, otras intentan adquirir una connotación científica y profesional al buscar las causas de la "anormalidad" y querer intervenir en "su alivio". El "incorregible" es el alumno por corregir (evidenciando la paradoja) al que hay que aplicar técnicas para la domesticación, el conformismo y la seguridad pública. Así, es pertinente recordar la sentencia de Foucault: La racionalidad de lo abominable es un hecho de la historia contemporánea. Pero lo irracional no adquiere, por ello, derechos imprescriptibles (Blanchot, 1988).

En la casa de la niña, esta situación escolar no parecía ser relevante. La familia ha 
pasado por situaciones muy difíciles, como hace seis años, cuando el papá fue atropellado e intervenido para que no perdiera su pierna. Sonia tenía entonces ocho años y cursaba la escuela como repetidora por segunda ocasión. Es evidente que la familia atravesaba por un momento crítico, pero la escuela no tuvo referencia de ello o al menos no se consideró relevante. El dinero requerido para tal emergencia los endeudó fuertemente y el cuidado que requirió su recuperación hizo que la señora desatendiera a sus hijos pequeños. En su relato recordaba:

Como yo en abril voy a completar cuatro años que me aventaron, el día 15 de abril me aventaron a mí, yo tengo fierros de aquí hasta acá. Yo me aventé cuatro meses allá y ya le digo ahí si me cobraron, ahí el doctor si me cobró buena feria, serían $\$ 260,000$ pesos, nomás que mi viejita pos por ahí consiguió, la gente le ayudó y por ahí vendimos unos animales, unos marranitos que teníamos para estos que estaban chiquitos. Bueno, como quiera que Dios les echa de gane, de mi pie que no me mocharon mi pie; y bueno ya andamos trabajando. Yo lo que no me duele, yo lo que me canso. Me canso del pie. Si levanto, pero me canso de mi pie.

La señora, por su parte al respecto dice:

No, pero padecí de una, o sea que mi señor se me enfermó, mis hijos estaban chiquitos y yo apurada por él, qué hambre me iba a dar, pensando en mis chiquitos, qué comerán, sólo
Dios. En el hospital, yo les agradezco a las personas que sabe, yo creo que como yo era muy platicadora y sabe no sé, yo creo les caía bien, me llevaban lonche, frijolitos con huevo, sólo Dios lo que les daba licencia; yo lo que hacía, mejor se los mandaba con alguien conocido: "Llévenle a mis criaturas, sabrá Dios si comerán". Y ya lo sacamos y él, puro huesito. Luego de vuelta, no batallé mucho. Después ya se me recobró, se me compuso.

A partir de entonces, él y su esposa consideran "la fe y la voluntad de Dios" ante todo. Lo importante para vivir es el sustento para la familia, que no siempre está asegurado ante la inestabilidad del ingreso y el trabajo eventual, pero que se valora y se disfruta en conformidad. El padre asume el papel de proveedor responsable aun cuando físicamente se encuentre en desventaja para trabajar. Orgullosamente habla:

Yo me la paso muy bien aquí en mi casita [...] ahí jalando en el jornal, hay días que trabajar, hay días que no trabajamos, no tenemos jale. Nomás que pos yo, por ahí lo que [...] me ayuda es que le entiendo a matar animalitos así de marranos en la plaza, o cuando hay una boda, una quinceañera, luego me vienen a ver a mí que vaya a matarlo. Gracias a mi Padre Dios que no me deja morir de hambre, Dios que me bendice, y ahí así los tengo a todos en la escuela... como ahorita el chiquitito que tenemos, a diario hay que comprarle los pañales, 
un bote de leche, luego comprar el mandado cada ocho días. Si me sobra me compro una cerveza y si no pos nomás una. Ahí mi 'jito tráeme una caguama para echármela ahí. Yo sí, cuando me voy de parranda a la jugada con mis amigos yo primero les arrimo de comer, ya le traje ahorita el mandado.

Actualmente, están pasando por otro momento difícil debido al abuso sexual del que ha sido víctima la hija mayor, responsabilizándose de la situación y tratando de que no se repita con las otras dos hijas. Al respecto, el señor refirió:

Sí, ahorita tengo este mampollete, el chiquito, ya cumple 10 años el 29 de mayo. Y el otro no es de esta muchacha. El muchacho más grande ya me ayuda, es bueno pa' hacer cuentas, ahorita anda pa' Zacatecas. Ella también anduvo pa'llá vendiendo también, jalando con una señora también. Nomás que ya no quise mandarla porque está muy lejos, está muy lejos allá mi nena y ahorita que le pasó "ese jale" por el chavalito que tuvo, no pos ahora menos; y yo cuando se la presté a la señora se la encargué mucho y fue lo primero que me hizo.

La madre en la casa, con las responsabilidades de los hijos, trataba de aconsejar y apoyar a su hija mayor.

Pos ahorita nomás lo de mi'ja que se fue a trabajar, como que ella no entiende muy bien qué le pasó, como que apenas, yo le digo: "Usted ya supo lo que es amar a Dios, ya tuvo su hijo. No vuelva. Que, si algún individuo la quiere engañar, no se crea, porque ya ve, el niño, qué caso tiene", pos ya ve yo estoy enferma; yo estuviera buena, y ni aun así pos no, no voy de acuerdo jंverdad? Y yo le doy consejos más que nada a ella, que ya se ponga lista, ¿̇verdad? Ya no se crea de nada, ya usted misma, por ahí tiene ora si un día puede salirle por ahí un compañero y él la acepta que bien, pero si no, a mí también no me estorba, aunque sea frijolitos no nos falta qué comer. Le digo, aquí estese. Como se apura mucho, porque el papá le compra pañales, leche, su papá es el que le compra todo. La hermana le dice que ella ya mero iba a andar dejándose agarrar de un viejo, que ella le mete un guamazo. Por eso ella quiere trabajar en otro lado, pa' su niño.

La escolarización de los hijos ha significado un gasto fuerte que hay que solventar para obtener la certificación, que en la vida es importante para adquirir un trabajo y conservarlo. El padre comenta:

Como ahorita tengo en la primaria ésta y éste y esa más chiquilla, pero no, como quiera yo... Como ahorita está una cuota de 150 jंverdad? y ahora que salgan todos los niñitos, ahí van a pedir los papeles y van a decir: "Órale, żquién es la que debe?" $Y$ tiene que pagarle uno $\mathrm{pa}^{\prime}$ que le den los papeles, si no, no le dan los papeles. Como quiera yo le digo a ella, la viejita, 
no tú échale ganas, no hay que desmayarnos, hay que tener fe en Dios y que no nos falte qué comer. Está el dicho que donde hay familia hay que comer, no nos falta nada. Nos la pasamos bien y sí, ahí andamos.

A diferencia de cómo es catalogada por la escuela, esta familia ha funcionado tratando de resolver las dificultades y enfrentando las consecuencias que implica la ignorancia y el analfabetismo de los padres. La escuela juzga como desinterés o poca preocupación de los padres por la escolarización de los hijos al desconocer las experiencias que esta familia ha tenido debido a ello.

La alumna es una niña que está arribando a la edad de la adolescencia. Lo poco que ha expresado de sí misma y de su familia lo ha hecho con alegría y orgullo. Tiene aspiraciones como cualquier niña y de manera implícita manifiesta su deseo de ser aceptada.

Yo tengo 12 años. Vivo en Corte Primero. Estoy en $3^{\circ}$. Soy alta y morena. Mis ojos son cafés y mi pelo es negro. Me gusta mucho la plaga [playa -es decir, la presa-]. En mi familia somos siete. Mi mamá, mi papá y mis hermanos. Mi papá es albañil. Mi mamá trabaja en la siembra. De grande quiero ser maestra.

Mexquitic de Carmona (cabecera)-Derramaderos: construyendo caminos y alargando distancias

Mexquitic de Carmona, cabecera del municipio del mismo nombre, se encuentra a $22 \mathrm{~km}$ hacia el noroeste de la capital del estado. Cuenta con una población de 924 habitantes $y$, registrados en el INEGI, 30 habitantes sujetos al proceso de inclusión. Es el lugar que tiene el más alto índice de alfabetización, pues de una población en edad escolar de 186, saben leer y escribir $154(82.79 \%)$. Curiosamente, la cantidad de sujetos con analfabetismo, 32, es directamente proporcional a la cantidad de sujetos al proceso de inclusión, aunque no se puede afirmar su correlación.

Durante la etapa de trabajo de campo, la carretera estaba siendo reconstruida, por tramos, como autopista, favoreciendo de esta manera la comunicación terrestre.

La escuela primaria "José María Morelos y Pavón" se encuentra a la entrada de la cabecera, al borde de la carretera. Es una escuela con una superficie similar a las dos escuelas anteriores, deteriorada en sus instalaciones, pero muy bonita, que está construida por niveles, dadas las características del relieve que es montañoso. Está rodeada por una barda de un metro de altura aproximadamente, de piedra de cantera, en arcos inversos y barandal metálico en la parte superior (figura 4). La puerta de entrada es también un gran barandal metálico que tiene un candado, pero que casi nunca está puesto, está ubicada en el primero y más alto nivel, da a un pequeño espacio abierto $y$ techado que sirve como estancia de entrada. Hacia la izquierda se encuentra un edificio, cuyo primer salón está ocupado por la dirección, y los siguientes se usan como aulas. Frente a la 


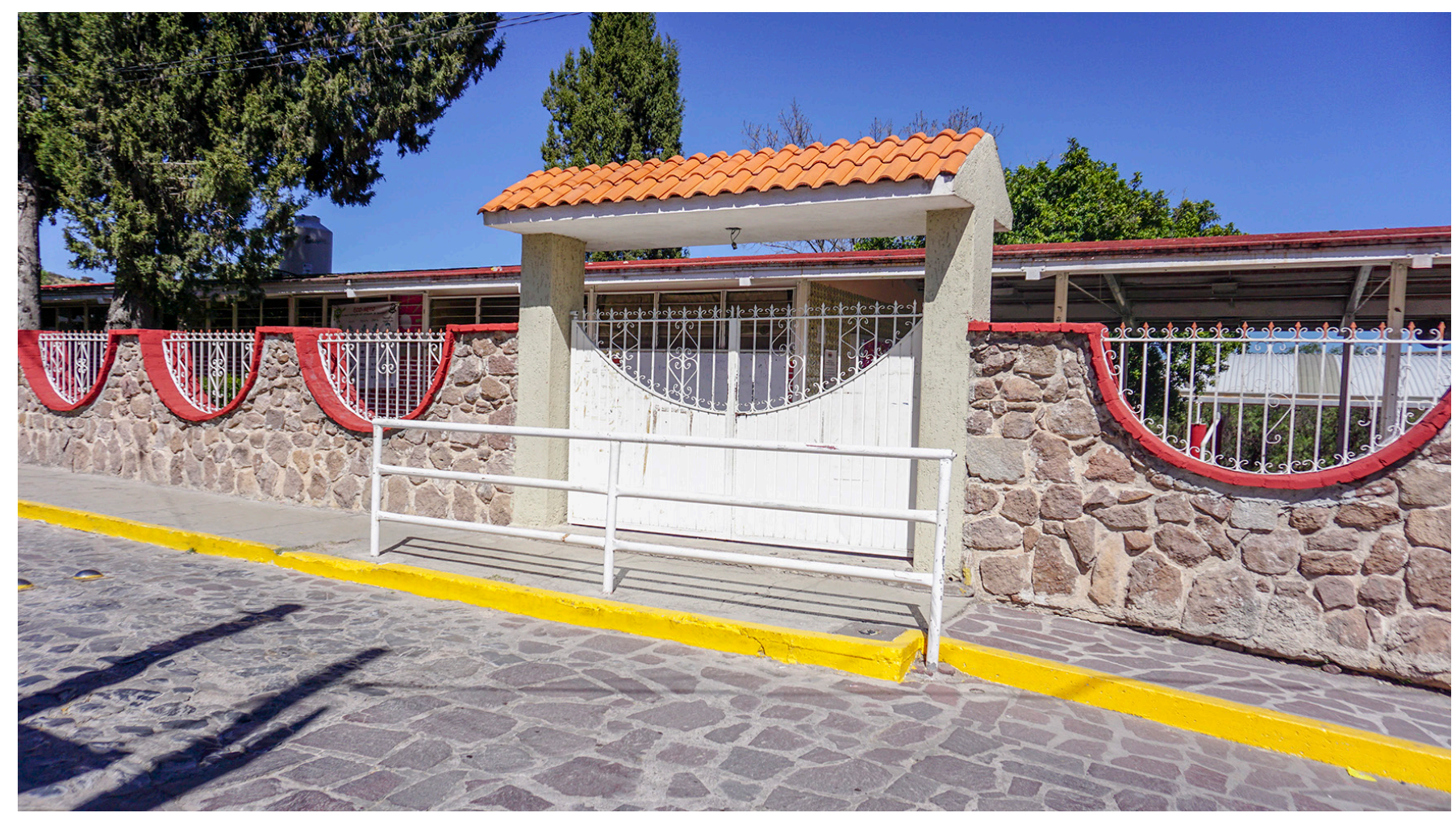

Figura 4. Entrada principal de la Escuela Primaria "José María Morelos y Pavón".

estancia de entrada hay una amplia y regular escalera de piedra que desciende al segundo nivel, en el que en encuentra dos amplísimas áreas deportivas: la primera es una cancha con piso de cemento para básquet y volibol; y la segunda es de piso de tierra para practicar fútbol; se observan además áreas verdes alrededor. También hay hacia la izquierda otro edificio con aulas. El tercero y último nivel es de dos metros hacia abajo con respecto al segundo, en él hay un edificio donde se encuentran los baños y cuatro aulas.

El conserje, de aproximadamente 65 años, fue quien contó la reseña sobre la escuela. Según él:
Esta escuela se hizo en 1967, cuando estaba de Gobernador Don Antonio Rocha Cordero. Entonces se imponían los presidentes municipales de dedazo y él asignó a la Profesora María del Refugio Méndez Torres, de 1968 a 1970, oriunda de Armadillo de los Infante, que venía de haber trabajado en Charcas. Ella tenía varios años trabajando como maestra aquí cuando la escuela estaba a un lado de la iglesia, hacia arriba, donde ahora está el COBACH. Eran dos salones grandes, de adobe y piedra; y la casa del maestro, que casi nadie usó. Ellos utilizan un salón de la antigua escuela primaria. Nomás le pusieron techo de lámina porque ya no tenían techos. Esta primera escuela se fundó en 1927. Mi hermana, de 75 años, terminó ahí. 
Entonces nada más eran uno o dos maestros y venían muchachos de los ranchos, caminando. El Sr. Raúl Flores, ya es grande, tiene 90 años, él sabe la historia, nomás que ya no escucha. Yo también estuve ahí, pero el maestro venía, Nicolás Ibarra, (1944-1952-1958) nos ponía trabajo y se salía a tomar, luego regresaba y nos revisaba. Luego vinieron unos maestros de allá, del norte y esos sí eran buenos maestros y nos enseñaban.

La maestra gestionó la concesión del terreno y la construcción por parte del gobierno federal y estatal. Casi la mitad del terreno fue donado por unos señores que viven por la iglesia. La otra mitad era propiedad de varios de este lado. Costó ocho millones y tardaron seis u ocho meses para construirla: trabajadores, albañiles, electricistas, herreros, todos venían de San Luis, siendo dirigida por CAPFCE.

Además, comentó que:

Era la única escuela en todo el estado [se refiere tal vez a que fue la primera escuela rural o municipal]. Estaba muy bonita, tenía flores: rosales, guirnaldas... La maestra era muy estricta y la cuidaba mucho y no dejaba que los niños la destruyeran. El gobierno un tiempo le dio mantenimiento, pero después se desentendió, se la dejó a los padres y ya no le dieron igual cuidado. Si se han hecho reparaciones, como la reinstalación de la luz, reparación de baños [plomería] y techos [impermeabilización].
Yo empecé a trabajar en 1977 como velador y conserje [vive enfrente de la escuela]. Tengo 29 años trabajando aquí. En 1973, se fue la directora para la ciudad por problemas con la gente. Dicen que acabó mal, en el vicio.

Los maestros, todos van de paso. Unos duran 10, 11 años, otros dos o cuatro años, y se van. La casa del maestro no ha sido habitada en forma. Mejor ahora la usan para educación inicial. Esta es la única escuela aquí. Pa'llá de aquel lado de la playa [presa] querían hacer otra escuela, casi es gente que viene de fuera, de México cuando lo del temblor del 85, pero no lograron nada. Aquí vienen de Campana, Los López, Milpillas, Las Moras... prefieren venirse porque es muy dura la cooperación $\$ 400.00$ o tienen problemas en la comunidad.

Ahora ya hay muchachos con más estudios, hay profesionistas, pero tienen la tendencia de irse a San Luis: licenciados, enfermeras, arquitectos, contadores, maestros de educación primaria o de preescolar pero no se quedan aquí.

La historia de esta escuela recupera, desde la narrativa, la situación de la escuela rural mexicana, los actores principales: autoridades estatales y líderes locales, las épocas de su fundación, los procesos de gestión, la condición del docente (pobreza, marginación, alcoholismo, desvalorización social) que explican la lamentable situación en la que se encuentra la educación en este contexto y algunos de los 
principales factores que influyen en la calidad educativa.

En el ciclo escolar 2005-2006, se tuvieron 140 padres de familia, 226 alumnos, 13 integrantes del personal de la escuela, 8 maestros y 5 alumnos integrados.

El director de la escuela es originario de una comunidad de Guadalupe, como a $10 \mathrm{~km}$ de la cabecera municipal, rumbo a Zacatecas. Estaba por cumplir 30 años de servicio y se aproximaba su jubilación. En entrevista comentó que él como directivo había tenido la oportunidad de trabajar en dos escuelas, y consideraba que era un trabajo muy laborioso, más que nada por la organización del plantel y el trabajo con los padres de familia. En Mexquitic ya tenía como 20 años trabajando y se dedicó a la docencia porque para él era la única posibilidad de estudio.

Porque sí, nada más, porque aquí no había mucha oportunidad de salir a estudiar y en aquél entonces los maestros que trabajaban en las comunidades trabajaban en la mañana y en la tarde y les dio por abrir una secundaria aquí; era nocturna y ya de aquí nos fuimos a la normal, pues la mayoría de aquí estudiamos la normal porque no había oportunidad de otra cosa. Por alli, alguno que otro que tendría la manera de estudiar otra cosa, pero aquí [estamos] muchos profes que salimos de esa secundaria, seríamos unos tres ahí en la normal, pero todos los demás estudiaban en la normal "Patria", en la "Belisario"; y por eso, [estamos] muchos maestros aquí, ya todos nos estamos jubilando, pero la mayoría de aquí de Mexquitic salimos de esa secundaria.

\section{Sobre el lugar comentó:}

Bueno, a partir de lo que yo conozco, [...] Mexquitic es un municipio grande que poco a poco va saliendo de lo atrasado que estábamos, nada más que yo creo que se le debe de dar, la agricultura ya no deja porque ya no hay agua y el gobierno nada más está fastidiando porque antes no pagaban la luz tan cara, no pueden hacer un pozo porque tienen que pedir permiso, ya no pueden hacer otro porque el agua se agota. Entonces, por eso es que los muchachos salen, no tienen la oportunidad de la agricultura tampoco, salvo los que viven ahí con los papás, pero yo creo que, en las comunidades, con lo poquito que les da el gobierno, están mejorando, yo creo que están mejorando. Cualquier ranchito ya tiene pavimentadas sus callecitas, las becas de los niños que también es una buena ayuda para los papás, ya les queda para gastar en otra cosa para mejorar su vida... sí, poco a poco va mejorando; porque sin esos apoyos, de los muchachos que están mandando del otro lado y de lo poquito que les da el gobierno, pues no hay oportunidad de trabajar en otra cosa; solamente las fábricas que están poniendo para este lado, por Cerrito, por el periférico, que las comunidades que están cerca están aprovechando. 
También creía que, al ser del lugar, los maestros le ponían más empeño al trabajo, porque conocían a la gente. Entre sus experiencias contó:

Pues más que nada servir a los niños, a los padres, porque como yo soy de Mexquitic, pues tengo que echarle ganas [...] tratar de darle un apoyo a los paisanos, a los niños de aquí. Mi objetivo era llegar al municipio y se nos dio la oportunidad rápido y sí he trabajado la mayor parte de mi tiempo aquí.

Yo considero que el trabajo del maestro, del director... trabajar con alumnos es de los [trabajos] más bonitos [...] que hay, porque pues no cualquiera tienen la oportunidad de trabajar con seres humanos y de guiar a todos, pues que debemos de dar lo mejor de nosotros porque pues no se debe echar a perder a los niños, habremos maestros muy duros, muy malos que no hacemos conciencia del mal que les estamos haciendo a los niños; debemos de dar lo mejor.

Eso he buscado en las escuelas que he estado, yo considero que no estoy tan equivocado, me tocó trabajar en una profesión muy bonita. Aquí tengo once años cumplidos como director... sí, son bastantes; y antes decían que era una comunidad muy difícil, que lo padres de familia... pero pues en realidad no, yo creo que como les decimos a los compañeros que van empezando, yo creo que el trabajo es el que recomienda al maestro, a la persona; y no, has- ta ahorita aquí estamos bien, no hemos tenido hasta ahorita ningún problema.

El primer día de clases, durante el recreo, en la estancia de entrada había una gran mesa con venta de tortas, duros, atole o canela y dulces. Apenas era agosto y el aire ya se sentía frío. Los niños se formaban para comprar. La mayoría estrenaban uniformes, sobre todo los más chicos, que se veían un poco temerosos, pero que al encontrarse con sus hermanos mayores o amigos disfrutaban del juego y la comida. La mayoría de los niños se veían limpios y peinados. Algunas mamás les llevaban lonche a sus hijos y los acompañaban durante este tiempo. Unas llevaban a sus bebés cargados en brazos o de la mano a los que empezaban a caminar.

En ese momento, llamó la atención de la comunidad escolar la presencia de una niña chaparrita e inquieta. No traía uniforme, usaba pants y una blusa de manga larga. Otras niñas pequeñas la cuidaban. La maestra de apoyo se acercó hacia ellas y les preguntó que de dónde era la niña, si era hermanita de alguien o venía a acompañar a su mamá a traer lonche. Le dijeron que no, que estaba con ellas en su salón de primer grado y que la maestra les había pedido que la cuidaran en el recreo. La maestra de apoyo se dio cuenta que habría otra niña en el programa de integración educativa, pues presentaba síndrome de Down.

A la entrada del recreo, la maestra de apoyo fue a ver a la maestra de primero. La 
niña estaba allí, en la última banca de la segunda fila. La maestra de grupo regular le comentó que iba a requerir atención especial para ella. La maestra de apoyo comentó que se tendría que realizar una labor de sensibilización con el personal de la escuela para conocer "Ias características que tenían estos niños".

El enfoque interaccionista que subyace en el programa oficial de la integración educativa, si bien pretende conocer las capacidades más que las limitaciones, sigue centrándose en el niño, contiene una terminología en la que subyace un modelo funcional que bloquea la posibilidad de concebirse y concebir a los otros como seres completos, capaces de establecer relaciones, diálogos y encuentros entre sí para cambiar las significaciones sociales y "científicas" sobre las que descansan las prácticas sociales y educativas.

Jerez (1989) emplea una terminología evidentemente contradictoria al hacer una crítica a la forma como el otro es "tipificado" desde una relación dual de "normalidad", "anormalidad" sin por ello renunciar, tal vez de manera inconsciente, a las significaciones sociales instituidas sobre esta base binaria, por lo que denomina: "la negación fallida", a la intención de hacer desaparecer la diferencia entre "normales y atípicos", pretendiendo que sus vidas sean iguales, negando con ello la diferencia que caracteriza al sujeto "anormal".

Durante la primera mitad del siglo XX, Decroly y Montessori abogaron por una pedagogía basada en el tratamiento diferencial de cada alumno, a partir del descubrimiento de las diferencias individuales, superando esta visión binaria e identificando a éstas últimas como una condición presente en todos los seres humanos. Lo anterior dio paso a los principios de la Escuela Nueva que transformó la escuela tradicional al dar un lugar activo a la infancia (Narváez, 2006).

En el mes de octubre, la niña asistía al grupo de apoyo acompañada de una compañerita de su salón que la cuidaba, pues algunas veces se salía del salón y la maestra no podía cuidarla todo el tiempo. La compañerita platicó que, el día anterior, la niña se había ido al salón de $5^{\circ}$ grado y la maestra estaba muy asustada porque no la encontraban después del recreo.

La alumna tenía en este ciclo escolar 7 años. En una actividad de presentación, los niños estuvieron elaborando un escrito titulado: "Así soy yo" en el que estaba atenta e interesada porque, aunque la maestra tomaba su mano para ayudarle a escribir, sabía que estaba escribiendo su nombre y sus datos. No era entendible lo que decía, parecían sonidos guturales, sin embargo, sus expresiones faciales reflejaban cierta intencionalidad (molestia, agrado, interés).

En el recreo, algunos niños de $5^{\circ}$ y $6^{\circ}$ cuidaban a la niña, la cargaban y la consentían, aunque también otros la hacían repelar. Ella aprovechaba esta situación, dejándose cargar, abrazar y besar. También les pedía dulces y si no lo hacían, se tiraba al suelo, se quitaba los zapatos y quería pegarles. Muchas veces, 
con tal de que no se enojara, le daban lo que pedía.

En una ocasión, regresando del recreo, llegó llena de dulce en la cara y en las manos. La maestra de apoyo la llevó a lavarse al baño para poder continuar y le guardó su dulce en una caja; pero ella ya no quiso trabajar porque quería que le diera su dulce. Le dijo que después de que terminara su escrito. Se tiró al suelo, se quitó sus zapatos, gimiendo y apuntando hacia la caja. Un buen rato estuvo así, hasta que le explicó que ya se había lavado sus manos y su cara y que se mancharía otra vez si le daba en ese momento su dulce, que mejor esperara a que terminaran. Como vio que ahora iban a dibujar, se puso sus tenis y se sentó a trabajar con sus compañeros. La maestra le tomó nuevamente la mano para que se dibujara e iluminara su retrato.

Dos semanas después, en entrevista, la maestra de primer grado refirió que al menos la niña ya no se salía tanto del salón, que a veces platicaba con ella y entendía que no debía hacerlo. El problema era que, como no hablaba, sólo decía: "chi", para ir al baño o "mi 'má" para decir "mi mamá". Para darse a entender usaba la mímica, por ejemplo: con la mano hacía como que comía para decir que tenía hambre, o señalaba con el dedo las cosas cuando quería decir que algo era de ella. Todavía hacía berrinches, se tiraba al suelo, se quitaba los tenis y las calcetas. Tenía su libreta especial donde le ponía tareas la maestra de apoyo y en casa le ayudaba su mamá, pero en la escuela no hacía nada. Corría por el salón y quería que la maestra la persiguiera.

En el mes de febrero la mamá de la niña fue llamada a la escuela porque un día se había mojado toda y le tuvieron que quitar la ropa hasta que se le secara un poco. En otra ocasión, se había emberrinchado porque la maestra de apoyo le pedía que pronunciara, que dijera lo que quería hablando, con la idea de que la niña lo haría si se le exigía que lo hiciera.

El 22 de febrero fue el cumpleaños de la niña. Su mamá la esperaba a la salida porque el señor del camioncito no quiso ya llevársela, diciendo que: "por tres niños que llevaba hasta Derramaderos no le costeaba". En realidad, también le hacía berrinches al señor del camión, pues no se quería bajar y tal vez por eso ya no quiso llevarlos, a ella, a su hermano de $4^{\circ}$ y a otro niño de esa misma comunidad. Su hermano comentó en alguna ocasión a sus compañeros que él ya estaba "harto de su hermana".

La comunidad de Derramaderos, donde vive la familia de la niña, se encuentra a unos diez kilómetros de la cabecera municipal, de ahí es originaria la mamá. Esta última comentó con orgullo en entrevista, que ese día era el cumpleaños de su hija. Y luego añadió:

Hace ocho años, cuando cumplía un año, la estaban operando de un soplo en el corazón en México. Desde que nació ha sido llevarla con doctores, a atender a muchos lugares... Sólo su papá no tiene confianza en que ella pueda aprender. 
Durante una visita a la casa de la niña, se pudo observar que tenía un amplio solar y que la vivienda era una construcción de block que estaba hacia el poniente. Había ropa tendida y grandes tambos para juntar agua, pues sólo llegaba una vez a la semana y la almacenaban, pero como estaba muy amarilla, según comentó la mamá, sólo la usaban para lavar y ellos tomaban agua de garrafón. Un cuarto amplio servía de sala, limpia y alegremente pintada de color verde agua. Un reloj de pájaros estaba al centro de la pared principal, por arriba de un librero que tenía adornos y un estéreo. A un lado había una televisión. Una ventana grande permitía ver hacia el solar y hacia el camino. Al llegar de la escuela, el hermano se salió en la bici a encontrar a la muchacha que cuidaba a su hermanito de dos años mientras trabajaba su mamá. Ella apareció a lo lejos y traía cargado al niño. Más tarde, llegó su hijo de la secundaria de Mexquitic, tiene 19 años y está en tercero grado. La mamá dijo que su hijo mayor no le tenía paciencia y la trataba mal.

La madre expresó en su relato que había sido una experiencia muy dolorosa el nacimiento de su hija, debido a "su enfermedad". Esto podía parecer lógico dado que este suceso estuvo asociado con un problema del corazón que hizo necesaria una intervención quirúrgica. Su relato reflejó la tenacidad y fortaleza que ha tenido desde que su hija nació para que fuera atendida y recibiera educación. Recordó el temor de tener otro hijo con estas características cuando se volvió a embarazar. Comentó cómo no fue aceptada la niña por la escuela de su comunidad al no contar con las condiciones necesarias para su atención. La madre se ha mantenido firme, aún en contra de lo que pueda pensar la gente de la comunidad donde viven y su esposo, pues ella ha visto logros en la niña gracias a que ha recibido atención y apoyo. Refirió el gusto e interés de la niña por ir a la escuela, aunque se enfrentaba en ese momento al problema del transporte debido a la distancia entre su casa y ésta. Además de la distancia, el que ella trabajara dificultaba su colaboración con la escuela para brindar apoyo a la niña, lo cual hacía más lento su avance. Ella contó:

Mis papás son originarios de Derramaderos. Alli hice toda mi escuela primaria. Me casé y tuve mis dos primeros hijos: un niño y una niña. Luego, en el 97, mi esposo se fue al otro lado, yo me quedé embarazada, tenía dos meses; y él se fue y yo pasé todo mi embarazo, como quien dice, sola. Este, ya nació, ella es del 22 de febrero de 1998. Y ahí, desde que ella nació, este, yo, no sé qué pasó, porque yo todo mi embarazo fue normal, uno tiene que ir cada mes, yo cada mes iba al ISSSTE y ultrasonidos y nunca me dijeron: "Su niña viene mal", no, hasta que nació.

Con respecto a que la niña esté inscrita en la escuela de la cabecera municipal, comentó:

Yo supe que podía estar en la escuela porque yo anduve investigando de que hubiera un maestro 
de apoyo. Yo quería investigar un maestro que pagara por semana, que hubiera un internado para que ella aprendiera, porque sí, dicen que sí hay escuelas en San Luis, que sí los atienden con ese problema, pero yo, yo cómo le hago. Yo dije, si hubiera una escuela así de internado para ella yo la mandara, aunque fuera por semana, la llevara por semana o la trajera y así que ella aprenda, más que nada para ella, porque uno ya, hasta donde pueda; para que el día de mañana que uno falte se pueda defender, más que nada por eso. El papá dice: "No hay que mandarla pos a lo mejor no aprende". Yo digo que ahorita si ha avanzado, sí le he visto algo que ha avanzado.

Ella sí dice alguna que otra palabra. Ella sí hace por hablar, hasta se enoja porque uno no la entiende. Mi esposo me dice: "No le hagas caso para que ella empiece a decir". Ella sí se enoja porque no la entiende uno.

Yo le he visto que tiene las anginas muy inflamadas y yo le pregunté al doctor que le da la terapia... y él me dijo que no había problema, que ella sí podía hablar.

El tercer sábado de febrero, la casa se llenó de globos y un pastel adornaba la mesa. La niña soplaba las ocho velitas mientras su familia gritaba: ¡Mordida, mordida! En este contexto cobra sentido lo analizado por Pérez de Lara:
En lo que se refiere a la cuestión del sujeto discente (en la educación especial) hemos visto cómo se ha pasado, en cierto modo, de ser un sujeto parcelado, convertido en objeto de diagnóstico, clasificación y tratamiento tecnificados, a ser un sujeto requerido de presencia, necesitado de reciprocidad, lleno de significado; presencia, reciprocidad y significado son las claves del sentido social que nos hace verles como sujetos. Incluirles en nuestra cotidianeidad... es lo que ha dado esencia y existencia a nuestra capacidad de ser sujetos, precisamente por haber establecido una conversación. (Ibáñez, 1994 citado en Pérez de Lara, 1998, p. 219)

Con relación a la asistencia de la niña a la escuela, es una situación de conflicto pues el padre se opone ya que piensa que la niña no va a aprender. Al respecto, la madre indica:

A veces él [su esposo] me dice que para qué [la lleva a la escuela] si no va a avanzar. Yo le digo que yo sé, además yo soy la que ando, yo soy la que la lleva a las terapias, a todo. Yo nunca pensaba que iba a desmayarme y cuando le sacaron sangre de aquí me desmayé. Le estaban sacando sangre y me dijeron ¿quieres quedarte? $Y$ yo dije sí, nunca pensé que iba a desmayarme. Y yo me iba de aquí a las 5, 6 de la mañana a hacerle los análisis. Después hasta México, irme hasta allá, y luego se le abrió la cicatriz donde la operaron... 
Pos ahorita con la escuela, como uno también tiene que estar al pendiente en la escuela, como antes que estaban aquí [en la comunidad de Derramaderos], pero ahora que están hasta Mexquitic ya no puedo ir a todas las reuniones por mi trabajo.

Con respecto al cambio de escuela de Derramaderos, su comunidad, a Mexquitic de Carmona, cabecera; la madre refiere:

En la primaria de aquí, de Derramaderos sí estuvo, sí fue como quince días; pero pos ya que como la maestra dijo que para que no batallara, o sea, la maestra tenía grupo, tenía primero, segundo y todavía era directora.

No son muchos niños, algunos diez en cada grupo. Cada maestra manejaba un grupo. Tres maestras y era directora y ella me dijo que sí quería, que la mandara, pero nada más como que, como para que, si no tuviera yo quien la cuidara, y no era eso; para que anduviera allí así, pero que no le iban a poner la atención que ella necesitaba.

Lo que pasa es que aquí, aquí en esta escuela no hay maestro de apoyo que me la pudiera apoyar, por eso pregunté si allá en Mexquitic había maestro de apoyo y por eso también tardé un año para llevarla en lo que terminaba el otro niño la primaria [tercer grado], entonces, y ya así se acompañen los dos para ir a la escuela a Mexquitic; por eso, la metí ahí porque
[...] tenían maestro de apoyo a aquí que no tenían nada, no, mejor dije no, como sea, mejor mandarla para allá. Aquí se salía, bueno allá también se sale, pero aquí no me le hacían más caso, la dejaban sola y a lo mejor allá con más maestros, le ayudaban más.

La experiencia escolar de la niña ha sido difícil, pero gratificante también:

A mi hija sí le gusta ir a la escuela. Ella sí se levanta y se va a la escuela y se enoja cuando no va a la escuela, por ejemplo, a veces, como el día de pago que salen temprano, no la mando porque digo para qué. $Y$, a veces, ahorita de repente no la mando porque el camión ya no me la quiere traer hasta acá. El señor dice que no le costea venir hasta acá. Entonces, a veces, sí me da pendiente porque digo no se vaya por ay, no sabe ella.

Ahorita mi hijo se encarga de traérmela. Y ahorita en la pasada de aquí los que van a la secundaria se los llevan. Entran igual a las ocho en la secundaria. Ahorita le quiero preguntar a la maestra de apoyo qué días le va a dar para nada más mandarla esos días, porque ya toda la semana ya me da más pendiente. $O$ sea, nada más el día que tenga la maestra de apoyo.

Sí, apenas parece que se está integrando, pero toda la semana a mí se me hace muy difícil. O sea, si ha avanzado, pero el problema es 
ese nada más, el transporte. A lo mejor cuando terminen la carretera ya va a ser menos porque ya van a pasar por el otro lado los camiones, porque ya los carros, no van a ser muchos.

Ahorita todavía se quita los zapatos, que todavía hace sus berrinches así, pero ya es menos. O sea, ya es menos que antes, era la novedad de que siempre se salía, ahorita ya conoce, ya le va haciendo menos caso andar afuera.

En el preescolar pos yo nada más la llevé un año, pero fue muy poco tiempo, y los niños de preescolar la ven menos, como que sí la veían como que raro; pero la maestra les decía que ella no podía, que le ayudaran, y hay veces que unos niños sí y otros no.

En la primaria de Ahualulco sí hay apoyo, pero en escuelas más grandes, con organización más completa, o sea, allí hay hasta director sin grupo, tienen maestro de música; pero no [...] pude tenerla porque yo estoy como a un kilómetro, es en mismo Ahualulco, pero lo que pasa es que es más para arriba.

Tenía que dejarla ahí y luego ya subirme y luego bajar otra vez a recogerla y yo cuando los niños salen pos uno está ocupado también para ir a recogerla. Entonces está difícil.

En una entrevista posterior, el padre de la niña contó que: "Es una experiencia muy dolorosa tener una hija con 'síndrome de Down'..." y que es una situación que no alcanza a comprender ni a aceptar completamente. Desde el momento en el que recibió la noticia hasta el presente es una situación que no ha alcanzado a saber manejar o aceptar en su totalidad.

La adicción a las drogas y al alcoholismo del padre durante su infancia y adolescencia le hacen pensar que tal vez se deba a eso. Por eso, a pesar de las ideas machistas acerca de la culpa atribuida a la mujer, él ha decidido seguir al lado de su esposa. El mayor conflicto es aceptar que la niña es capaz de aprender, que ella también debe asistir a la escuela y que pueda llegar a ser una persona independiente y autosuficiente en un futuro. Lo anterior, no significa que no quiera a la niña y lo demuestra al no desear darla en adopción o aceptar que esté bajo la tutela de algún familiar; o bien, al haberse regresado de los Estados Unidos para donar sangre y estar presente en la operación de su hija.

En el 97 me fui pa'l norte, cuando yo me fui Isabel se quedó, mi señora se quedó embarazada de la niña; cuando yo me fui ella tenía como un mes de embarazo. Allá me la pasé y ella, pues, en su trabajo y pos se llevaba a los dos más grandes, estaban pequeñillos, se llevaba uno cargado y el otro en la mano, sí, sí ha luchado ella mucho.

Cuando se alivió le dije:

- iAh!, No, ipos qué bueno! ¿̇ qué fue?

Pos que niña; ya me estaba comentando del 
alumbramiento.

- ¿Fue niña? Ah, qué bueno, pos ni modo. Pero yo, yo escuchaba, como la voz diferente -. Y le digo:

- ¿Qué qué pasa?

- No, - me dice - Pero la niña no la tengo aquí.

-Entons, ¿̇en dónde la tienes? - pero yo la escuchaba como triste, verdad, diferente la voz.

-No, es que la tengo en San Luis.

- ¿Por qué o qué?

-No, mejor ahora que vengas te digo. -Pos como que no me quería decir, como que dudó, dudó unos instantes, entons yo dije: "Ah, canijo, pus qué pasaría" y ya le dije:

-Pus zqué pasó? Dime, qué.

-No, es que la niña no nació bien.

-iCómo!

-No, es que la niña nació malita.

Nuevamente, la situación de riesgo y las consecuencias físicas y biológicas al nacer con esta característica lleva a asociar la idea de "enfermedad" y de "discapacidad intelectual" en el padre quien relata:

Entons, este, pos sí, me dijo que había nacido con un soplo en el corazón y pos que, pos que... había nacido con síndrome de Down. Híjole, no, yo en ese instante sí, sí fue tremendo. Le dije: "No, pos ya ni modo. No, pos está bien."

Pero eso, casi, casi se lo dije nada más de, como quien dice, para yo también tranquilizarla. Para mí fue difícil aceptarlo y yo digo que todavía hasta la fecha, también, todavía como que no asimilo bien las cosas, bueno, ya ahorita es menos, pero en un principio yo decía, yo me preguntaba: "¿por qué a mí? o ¿por qué a nosotros? ¿̇Por qué Dios? ¿̇Por qué a mí?" $O$ sea, no encontraba una respuesta. Está medio difícil.

Entonces, ya para esto, me dijo que necesitaba de una operación que porque no crecía... la llevamos a México, al hospital 20 de noviembre. Entons me dijo, pa' tal día la van a operar, y quiero que estés aquí. No sí, yo sí vine, hasta eso sí vine, porque le digo, yo sí, yo sí, como una responsabilidad, no pos es mi hija, pos qué hago, pos ni modo, no está bien, pero es mi hija.

Entons cuando llegué y la vi como una monita, así, así, nomás estaba así, comía y nomás estaba así. Mi niño que tiene ahorita diez años la tenía así, como una monita, como una monita, - sea que no crecía, no crecía y estaba muy débil... yo tenía que venir a dar sangre para la transfusión de la operación. Y ella, yo tanteaba como que ella pensaba que yo, como que ya, como que ya no íbamos a seguir. Yo sentía que ella tenía temor de que yo la abandonara. No, pero sí, yo me ponía a pensar, a reflexionar. Si yo no hubiera pensado las cosas, yo digo, pos uno de hombre es bien machista, dice: "No pos la mujer no sirve", dice uno, la palabra clásica de uno: "No pos la mujer malparió, no pos pa' qué sirve". No, no, no. 
Una consecuencia es la forma de pensar que la mujer puede ser la responsable de la situación, pero el padre reconoce que de joven estuvo expuesto a la drogadicción y al alcoholismo y llega a relacionarlo con las dificultades y riesgos en su nacimiento y desarrollo.

No, entons este, yo nunca pensé de abandonar a mi mujer por esa situación. Yo dije: "Híjole, pos ni modo, pos ahora a atorarle, a lo que venga". De repente como que sí me agüito. El día que uno no esté, pos quién va a cuidar de ella, porque como dicen, ellas son personas que cualquier persona puede abusar de ellas.

Entonces yo digo, tantas cosas de drogadicción [que] pasó uno, no pasé gran cosa verdad, porque yo probé la droga, pero, pero me salí yo a tiempo se puede decir, y pienso yo, cuando pasó lo de mi hija, que ya la vi yo aquí, se pregunta uno: "¿por qué sería?" A lo mejor porque en mi infancia probé la droga, puede ser, o no la droga sino el alcohol, o no se sabe... Y entonces si yo no hubiera pensado las cosas, más que nada, falta de responsabilidad, si yo no hubiera sido responsable, yo le hubiera dicho: "Sabes qué, no pos a ver, dale tú por tu camino y yo me voy con otra que no me de malos hijos"; pero es que uno no sabe; pero yo estoy con ella, y estaré con ella y yo como le he dicho: "Yo estoy contigo hasta donde topemos, hasta el final."

Los hermanos viven esta disyuntiva entre las creencias establecidas socialmente, asumi- das por el padre, y el actuar de su madre, que las rompe y las cuestiona. Su hermana relata la experiencia escolar de la niña en la comunidad de origen:

Ella antes de estar en Mexquitic estuvo antes aquí un tiempo, en primer año en la escuela de Derramaderos, la metieron a principios de ciclo y la sacaron en enero o algo así, porque la maestra no podía con ella como, por ejemplo, si iba al baño, se llevaba a la maestra y la maestra dejaba solo al grupo; entonces mi papá dice que sí era mucha batalla para la maestra, por eso.

[...] también la maestra nos dijo que ella no podía estar con la niña, o sea, haciéndole caso nada más a ella y dejar al grupo solo. La verdad es [que] la gente decía que la maestra nomás estaba dedicándole el tiempo a ella. Cuando estuvo en el jardín de niños, mi mamá se la llevaba, entonces mi mamá le ponía atención. Mi mamá se esperó un año, hasta el próximo ciclo y luego ya la llevaron a Mexquitic. Habló con el director, fue a ver si tenían apoyo para ella, por lo de su enfermedad.

De esta forma, es la madre quien reivindica la condición humana de la niña ya que lucha por enfrentar la situación excluyente vivida ante el rechazo y la vergüenza de sus hermanos, la incredulidad del padre en sus capacidades, el cambio de escuela, las distancias y la escuela "integradora" que aún conserva prácticas segregacionistas. 
El conjunto de significaciones sociales que circunscriben el proceso de inclusión educativa, en este caso, contradictorias y de resistencia, enmarcan la dificultad en la que se encuentran los sujetos: docente regular y especial, padres, familia, comunidad, por aceptar que la escuela es un ámbito posible de acción en el que todos podríamos "recuperar la capacidad de ser sujetos".

\section{Hallazgos}

Las condiciones geográficas, económicas, políticas y sociales que circunscriben el medio rural en la actualidad obligan a replantear lo que Santos (2006) argumenta al respecto:

Se hace necesario reconstruir la discusión en torno a la búsqueda de la igualdad de posibilidades entre los niños de las escuelas públicas, tanto rurales como urbanas. Búsqueda tensionada por la diversidad de los contextos que sigue siendo inevitable considerar. Tanto del punto de vista pedagógico -didáctica multigrado, aprovechamiento del potencial educativo del mediocomo desde el punto de vista social -la estrecha relación escuela-comunidad-, la diferenciación entre los medios rural y urbano sigue vigente. Diferenciación que demanda de la educación propuestas alternativas para cumplir con el desafío de la igualdad a partir de la diferencia. (p. 99)

Lo anterior, no significa que se renuncie a la universalidad del saber como legado de la especie humana, ni a la presunción falsa de la diferencia en las capacidades de los individuos por el contexto al que pertenecen. Romano (2006) retoma, en ese sentido, dos principios de justicia desde los cuales es posible pensar la política educativa de manera distinta:

Uno es el que plantea Julio Castro: cualquier política educativa debe partir de lo que hay... (que se opone a lo establecido actualmente: "partir de lo que falta"). Siempre hay aunque falten muchas cosas. Y lo que nunca puede faltar es la inteligencia. Ninguna sociedad democrática que pretenda integrar a todos los miembros que la componen pueden partir del supuesto de la existencia de la peor de las pobrezas: "la pobreza mental" (Rama). La pobreza mental es un concepto claramente ideológico que inhabilita políticamente a un importante grupo de la población, al tiempo que lo condena a la disyuntiva de ser, o bien asistido, o bien tutelado... Compartimos la idea de que debemos partir siempre de la "igualdad de las inteligencias". El otro principio, planteado por Reina Reyes es... que: La función de la educación no debe estar ligada a otra condición que no sea el hecho de desarrollar lo humano en cada uno de los miembros de la especie. Lo humano no es algo que pueda ser tipificado en función del contexto. Lo humano es universal y su concreción supone desarrollarlo en cada uno en singular, más allá de las condiciones en que se habita. (pp. 158-159) 
Por otro lado, un común denominador, en los casos expuestos, son la pobreza y la exclusión, dos rasgos del capitalismo inhumano. Como lo señala Bordoli (2006) en los actuales discursos normativos de la educación, las razones históricas de éstos no se dicen, se ocultan e incluso devienen como "algo natural y lógico" desplazando la responsabilidad hacia los sujetos que la padecen y no hacia las razones políticas y económicas que las provocan. De esta forma, el significante igualdad se omite, en tanto los enunciados anclan sentido en el discurso sobre la diferencia, pero no en una diferencia auténtica, en cuanto seres únicos e irrepetibles, sino en una diferencia ilusoria, imaginaria, producto de la clasificación discursiva en poblaciones según diversos atributos: grupos con capacidades diferentes, sujetos carenciados, grupos minoritarios, por citar algunos ejemplos.

En contraparte, los casos ilustran también de manera evidente cómo responden los sujetos a los procesos de exclusión/inclusión social y educativa, la posibilidad que tienen en la toma de decisiones y la capacidad que se muestra para dar respuesta a los problemas que se presentan en todo proceso vital, sin dejar de lado, las limitaciones y los obstáculos a los que se enfrentan. Amadeo (2003) recurre al concepto de "resiliencia" para explicar este proceso psicológico y social en los seres humanos, mismo que se refiere a la capacidad humana individual o colectiva de enfrentar la adversidad y, además, salir fortalecidos de ella. Cantero (2006) le denomina: la capacidad de incorporar contradic- toriamente, aún en un entorno de hegemonía y sometimiento que rodea a las clases populares, modos alternativos de responder a una situación de dominación. Históricamente, connota al concepto de sector popular como saber colectivamente enriquecido, como un modo de ejercer su ciudadanía.

Finalmente, la presentación de estos casos permite considerar que la formación docente, como experiencia vivida, dentro de los procesos de exclusión/inclusión educativa, es múltiple y diferenciada, de acuerdo con la historia de vida de cada uno de los sujetos y a partir de los contextos geográfico, sociocultural, político y económico en los que se desenvuelven y por los que transitan. De esta forma, lo indeterminado posibilita la acción y la capacidad de respuesta a través de la relación que se establece con los "otros" ante los factores que determinan lo educativo. Siguiendo a Pérez de Lara (1998), se recupera la capacidad de ser sujetos, tanto de los alumnos como de los docentes. Recurriendo nuevamente a Cantero (2006), se apela a una ética educativa que se cimienta en el conocimiento, la intuición, el afecto y la conmoción, que suscita el vínculo cotidiano con ese otro y sus circunstancias $y$ que explica la pasión que a veces transforma a la docencia en una forma de militancia, en una utopía política construida a partir de una falta radical y que potencia una construcción social asentada en vínculos altruistas y solidarios al interior de los sujetos y en su escenario institucional: la escuela. 
La concepción del ser humano como capaz de desarrollarse y aprender a partir de la aceptación y el reconocimiento del(os) "otro(s)" es un principio que, a manera de pivote, potencia estos procesos básicos en los individuos; y abre la posibilidad de favorecerlos y apoyarlos positivamente.

Con base en lo anterior, se desea sustituir la categoría de "sujeto de la educación especial" citado aquí por el de "sujetos del proceso de inclusión educativa" para considerar a todos los que participan en el mismo con la intención de reflexionar en la toma de conciencia acerca de la posibilidad de construir, desde el papel que juega cada uno de ellos en dicho proceso, una "alteridad transformadora" que reoriente e instituya con nuevas significaciones sociales para la reconstrucción de nuevas identidades.

La Teoría Educacional Crítica recupera, desde otra perspectiva, la categoría diferencia que cobra relevancia a partir de los procesos de identidad y de los movimientos multiculturales críticos. En lugar de quedar oculta, se transforma en un concepto clave que se funda en la convicción de que para la escuela es una prioridad ética dar poder al sujeto (McLaren, 1984).

En la primera perspectiva, el sujeto de la educación especial corre el riesgo de quedar subsumido en una diversidad totalizante y esencializada que, bajo la mirada de la aceptación y la tolerancia, sigue siendo hospedado por otro que representa la normalidad pretendida. Como telón de fondo, desde una supuesta igualdad y armonía, lo que prima es una concepción asimilacionista y acrítica del otro "diferente".
En la segunda perspectiva, en cambio, el sujeto de la educación especial, en tanto constructor de la cultura, es sujeto de su propio discurso; en tanto sujeto de la historia y constructor de su identidad, es capaz de vivir en una "alteridad transformadora" (Caterina Lloret, 1998 citada en Guglielmino et al. 2003, p. 70).

Es así como, los relatos de vida de los "otros" fueron dispositivos ideales para "volver la mirada hacia uno mismo" (Guglielmino, Valente y Mendes, 2003); no sólo del investigador con relación a los sujetos entrevistados sino, y esta es la apuesta del presente trabajo, del encuentro que de sí mismos puedan tener los profesionales de la educación. De manera especial, se considera por demás interesante qué de sí mismo, qué de diferente y en qué difiere la primera percepción de directivos y docentes con respecto a la que elaboran después de haber "escuchado" (leído) el testimonio de los otros: los padres de familia y los alumnos cuando se abre la posibilidad de escucha y de diálogo abierto. Una primera transformación reside en los procesos de identidad que pueden construirse al dejar al descubierto los procesos de alteridad preconstruidos o prefijados socialmente. Ante la pregunta: ¿quién es el otro?, se puede reconocer, a través del relato construido, que no es quien se imaginaba o quien se pensaba inicialmente e incide en las preguntas necesariamente seguidas: ¿quién soy yo? y ¿̇por qué pienso así? Entonces puede hablarse de un proceso de reivindicación humana, de encuentro y redescubrimiento del otro que altera y propone nuevas formas de relación social y educativa. 


\section{CAPÍtULO 5}

\section{Consideraciones finales}

La finalidad de este libro es dar a conocer cómo se desarrolla el proceso de inclusión educativa en el medio rural a partir de las voces de los sujetos involucrados: directivos, docentes, familias y alumnos; así como su repercusión en el campo de la formación docente.

Partir de un enfoque crítico y el empleo del método biográfico narrativo permitió conocer los procesos de inclusión educativa y formación docente desde una perspectiva holística que considera los factores naturales y sociales como un movimiento múltiple y multidireccional, recuperando principalmente la naturaleza de lo humano, como parte esencial de todo proceso educativo.

Al hacer referencia al concepto de lo rural, éste se define como una mezcla de modernidad económica y diversidad social a partir de los datos estadísticos oficiales y de la descrip- ción de las condiciones geográficas, sociales y económicas. El medio rural es un espacio donde confluyen riqueza y pobreza de manera dramática, puesto que los ingresos económicos no tienen relación directa con el nivel de calidad de vida que se espera entre sus pobladores. Se hacen evidentes las formas de desigualdad, justicia y equidad social derivadas de un capitalismo económico y político agobiante. Lo que emerge como una constante es el marcado contraste en la coexistencia del lujo superfluo de unos cuantos con la miseria atroz de las mayorías; asimetría y desigualdad en Latinoamérica y el resto del mundo.

Con base en los casos presentados, se puede decir que la inclusión educativa en el medio rural y su relación con el campo de la formación docente se limita y circunscribe, a través de un imaginario social instituido y ho- 
mogeneizado, por una lógica de competencia académica y organización escolar que evidencia fuertemente la exclusión de aquellos grupos con mayor desventaja. Sin embargo, gracias a la imaginación radical, los sujetos tienen espacios, condiciones y situaciones muy limitadas tal vez y eso es motivo de todo un planteamiento, en el que tienen que desarrollar la capacidad de tomar decisiones y elegir el sentido de su existencia, orientándose por las condiciones sociales externas.

Docentes y directivos que dan testimonio de su experiencia, a través de estos casos, enseñan que la escuela puede ser un lugar de reproducción y hegemonía, de selección y exclusión 0 , por el contrario, un lugar que asume el carácter político y cultural que juega la escuela, donde se generan pequeñas transformaciones sociales.

La deserción y la reprobación escolar son el principal problema educativo y algunos de sus principales obstáculos son, como lo muestran los casos presentados, la rigidez y verticalidad administrativa, ajena y cerrada en sí misma que -se insiste- no toma en cuenta la sabiduría popular, la dinámica familiar, laboral y social de la comunidad como, por ejemplo, los ritmos y ciclos temporales, los saberes propios y comunes, las actividades productivas, las condiciones ambientales y las necesidades e intereses más apremiantes de la comunidad.

En ese sentido, la escuela, bajo una lógica de competitividad y rendimiento académico sólo se relaciona con los padres de familia a través de juntas para indicarles la obligación de apoyar económicamente en el mejoramiento material de su edificio y en el cumplimiento de tareas de sus hijos, desconociendo la situación en desventaja de la mayoría en ambos aspectos.

Por otra parte, la escuela rural, centrada en tareas de alfabetización y operaciones básicas, no logra aplicar estrategias para el abordaje de contenidos establecidos en los planes y programas que sean acordes a la realidad del medio, misma que es conocida parcialmente, sin que se observe un acercamiento con la población, atendiendo a sus necesidades e intereses, esto provoca que la escuela no llegue a ser una garantía para el mejoramiento de vida de la localidad. La población con mayores desventajas sociales se mantiene en un nivel de sobrevivencia o al margen del bienestar social y calidad de vida al que se tiene derecho.

Los docentes, ante las exigencias de las autoridades de cumplimiento con un programa y de participación en los procesos de evaluación y promoción laboral, aplican diversas estrategias de "selección" entre los alumnos más aptos y menos aptos para responder a dichos requerimientos: cambios de comunidades, de escuelas, de grupos, de maestros o de turnos, a pesar de contar con la infraestructura óptima, los recursos materiales y humanos suficientes para atender a la población escolar. El grupo de apoyo recupera a los alumnos con mayores desventajas sociales, culturales y económicas, quienes continúan siendo excluidos de la escuela y del sistema escolar. Esta grave situación 
contribuye a reproducir las condiciones de desigualdad e injusticia social.

Por tanto, con respecto a la educación básica en el medio rural, se puede decir que las comunidades más grandes en población tienen acceso cercano a una escuela (con la salvedad de la secundaria que puede ser sustituida por una telesecundaria), sin embargo, la escuela primaria deja de lado (o niega) la idea de que es, si no el único, sí el más importante recurso educativo que pudiera coadyuvar en el mejoramiento de las condiciones de vida familiar y comunitario.

En el caso de los alumnos sujetos al proceso de inclusión no se puede afirmar que se haya cubierto el criterio de cobertura $y$, desafortunadamente, menos aún el de calidad. La comunidad sigue considerando las diferencias físicas u orgánicas como sinónimo de "enfermedad" por lo que mantiene a los sujetos escondidos y silenciados por sus familias, recibiendo, en el mejor de los casos, asistencia médica cuando se hace indispensable para la conservación de la vida. La escuela no menciona esa realidad, más bien la refuerza ante la idea de que "no aprenden" o "no tienen la capacidad" para estar ahí; más aún, continúa evadiendo la responsabilidad de aceptarlos, buscando contar con "las condiciones adecuadas" para ser atendidos, cuando la condición principal es el cambio en las representaciones sociales sobre la diferencia y el compromiso político y ético de los profesionales de la educación. De esta manera, se sigue reproduciendo la negación de su existencia.
Otros alumnos, cuyas desventajas están dadas por la condición de género, de etnicidad, de pobreza extrema, del ambiente social o familiar, por mencionar algunas, son caracterizados en la escuela como sujetos "con discapacidad" o bien como "sujetos con necesidades educativas especiales", sin serlo realmente, ignorando con ello las verdaderas causas que obstaculizan su desarrollo y su aprendizaje, principalmente, la pobreza y la injusticia social.

En contraparte, hay directivos y docentes que logran favorecer formas de promoción y mejoramiento en las condiciones de vida cuando se reconocen y reconocen en los otros la capacidad de ser sujetos, favoreciendo con esto la posibilidad de aprendizaje y de convivencia en y desde la escuela, esto es, cuando se descubre la condición humana en lo educativo. De esta forma, lo indeterminado posibilita la acción y la capacidad de respuesta a través de la relación que se establece con los "otros" ante los factores que determinan lo educativo. Siguiendo a Pérez de Lara (1998), se recupera la capacidad de ser sujetos, tanto de los alumnos como de los docentes. Por otra parte, Cantero (2006) apela a:

una ética educativa que se cimienta en el conocimiento, la intuición, el afecto y la conmoción que suscita el vínculo cotidiano con ese otro y sus circunstancias y que explica la pasión que a veces transforma a la docencia en una forma de militancia, en una utopía política construida a partir de una falta radical y que potencia una construcción social asentada en vínculos altruis- 
tas y solidarios al interior de los sujetos y en su escenario institucional: la escuela. (p. 208)

El hacer docente se traduce en un "estar comprometido" y "actuar con compromiso", como sinónimo de ética profesional, al asumir la responsabilidad de pensar en y con los otros, principalmente, con los grupos más desfavorecidos. Esta "toma de conciencia" alude a ser protagonista en la toma de decisiones con respecto a buscar el mejoramiento de las condiciones de vida propia y como colectivo, como condición para el desarrollo humano.

La problematización que plantea la pedagogía crítica acerca de cómo se han construido las diferencias en torno a los sujetos de la educación especial -y la de todos los sujetos- posibilita la construcción de una probable pedagogía de la diferencia (Guglielmino et al., 2003).

Hoy en día, las comunidades necesitan recuperar su escuela como un espacio por $y$ para su servicio, en tiempos y espacios flexibles, con actividades diversas e interdisciplinarias, un lugar para el diálogo y el encuentro entre personas que comparten una realidad distinta, pero con metas comunes: el mejoramiento de la calidad de vida de sus habitantes.

Sobre el campo de la formación docente, se considera indispensable abordar los procesos de formación profesional, considerando su naturaleza humana dado que, como puede verse en este trabajo, son los aspectos afectivo-emocionales de las relaciones humanas y de los vínculos pedagógicos la base del desarrollo y el aprendizaje en general, más que los aspectos físicos o cognitivos. En la inclusión educativa, la recuperación de la propia identidad profesional, por medio del trabajo colaborativo con otros profesionales, desde la experiencia vivida, permitiría inventar nuevas formas de "ser docente" y "hacer la docencia".

La innovación pedagógica, en la especialización y formación permanente son importantes, pero se convierten en un campo estéril si no se cambia la mirada hacia el lado humano del acto educativo. Ver a los sujetos desde esta perspectiva transforma el encuentro con el (los) otro(s), donde se redescubren, se comunican, se relacionan a través de formas no imaginadas, dando paso a otras posibilidades de desarrollo social e individual.

El "ser docente" precisa una recuperación de sí mismo como sujeto completo, complejo y social. Significa: "estar implicado y reconocerse", como sinónimo de identidad, en el sentido de ser capaz de identificarse con los otros, de una toma de conciencia con respecto a las diferentes situaciones y modos de vida a las que se enfrentan. Es posible que la condición de origen de pobreza y la marginación como experiencia vivida generen cierta "sensibilidad" y "entendimiento" en la relación educativa.

De esta manera, puede reconocerse la fundamentación filosófica en el campo de la formación docente y de la inclusión educativa, así como la necesidad de una mirada transdisciplinar: antropológica, histórica, sociológica 
y pedagógica que parta de una posición antipositivista, es decir, de "sospecha y duda" sobre el carácter científico de la realidad social y ofrezca, desde el paradigma de la complejidad, nuevos elementos para imaginar e inventar distintas formas de abordaje y tratamiento. Las tareas de selección, diagnóstico e intervención psicopedagógica darían paso a estudios políticos, sociodemográficos y culturales de los contextos para el diseño de acciones de intervención social y política con el fin de resolver problemas desde un enfoque participativo $y$ comunitario. La formación significa pues una relación interactiva entre teoría y práctica por lo que la profesionalización docente se torna permanente, general y común.

Como establece Pérez de Lara (1998):

Es imprescindible pues la "supuesta muerte del sujeto moderno", racional y arrogante, que se cree protagonista de la Historia, controlador y dominador de la naturaleza y dar paso al renacimiento de un nuevo sujeto que le permita reconocer su "ser en relación con otros" en la convivencia como colectivo para crear "nuevas subjetividades emergentes". (p. 220)

La consideración de las diferencias individuales o naturales y sociales o culturales es un universal que incluye a cualquier persona o grupo en relación con otro $u$ otros y que transforma sustancialmente la manera de concebir y pen- sar los procesos de inclusión educativa como formas o estrategias por y para la convivencia social y democrática. Este primer planteamiento conlleva, por tanto, su correspondencia con un concepto de igualdad sobre los derechos universales de la condición humana en escenarios diversos específicos. La igualdad se traduce entonces en apoyar para superar o bien minimizar las desventajas de los grupos más vulnerables, es decir, en reducir las desigualdades a través del derecho a la educación. Esta reconquista del poder de lo educativo donde la igualdad, considerada de orden esencial, sustantiva, en tanto necesidad inherente a la especie humana de ser diferente, es decir, radical, ontológica y singular, es la base para "movernos" de falsas clasificaciones que manejan los actuales discursos sociales y políticos (Bordoli, 2006).

Desde otros puntos de referencia y desde bifurcaciones posibles se apela a "lo intercultural" que analiza el aspecto moral de los usos de la diversidad (Geertz, 1996), el respeto de las diferencias, el derecho de la diferencia, sin que esto se reduzca a una ideología del gueto y la exclusión (Augé, 1998); la preocupación por corregir la desigualdad y conectar a las mayorías (García, 2004), la ética de la diferencia (Etxeberría, 2000) y los procesos de ciudadanía como creación política en la pedagogía con un enfoque crítico-social (Freire, 1993; McLaren, 1984) para establecer nuevas maneras de relación humana y educativa. 


\section{REFERENCIAS}

Aguado J.C., \& Portal, A. (1992). Identidad, Ideología y Ritual: Un análisis antropológico en los campos de educación y salud. México: Universidad Autónoma Metropolitana.

Alegre de la Rosa, O.M. (2000). Diversidad Humana y Educación. Málaga: Aljibe. Alliaud, A., \& Duschatzky, L. (Comp.). (1998). Maestros: Formación, práctica y transformación escolar. Buenos Aires: Miño y Dávila.

Amadeo, M.J. (2003). La resiliencia como horizonte de expectativa de la educación especial. En Educación Especial. Inclusión Educativa. Nuevas formas de exclusión. Buenos Aires - México: Noveduc.

Anzaldúa, A.R. (2004). La docencia frente al espejo. Imaginario, transferencia y poder. México: Universidad Autónoma de México.
Augé, M. (1998). El sentido de los otros. Barcelona: Paidós.

Barton, L. (Comp.). (2008). Superar las barreras de la discapacidad. Madrid: Morata.

Barton, L., \& Torres, J. (1998). Discapacidad y Sociedad. Colección Educación Crítica. Madrid: Morata.

Benveniste, E. (2004). El aparato formal de la enunciación. En Problemas de lingüística general II. México: Siglo XXI.

Berenzon, G.B. (1999). Historia es inconsciente. La historia cultural. Peter Gay y Robert Darnton. México: El Colegio de San Luis.

Blanchot, M. (1988). Michel Foucault tal y como yo lo imagino. España: Pre-textos.

Bolivar, M., Segovia, J., \& Fernández, M. (s.f.). La investigación biográfico-narrativa en educación. Guía para indagar en el campo. España: Grupo FORCE/Universidad de Granada. 
Bolívar, M., Segovia, J., \& Fernández, M. (2001). La investigación biográfico-narrativa en educación. Enfoque y metodología. Madrid: La Muralla.

Bordoli, E. (2006). El olvido de la igualdad en el nuevo discurso educativo. En P. Martinis, \& P. Redondo (Comps.), Igualdad y educación. Escrituras entre (dos) orillas (pp. 185-204). Buenos Aires: Del Estante Editorial.

Calvillo, U.T. (Coord.). (2002). San Luis Potosí: Sociedad, economía, políica y cultura. México: UNAM.

Cantero, G. (2006). Educación popular en la escuela pública: una esperanza que ha dejado de ser pura espera. En P. Martinis, \& P. Redondo (Comps.), Igualdad y educación. Escrituras entre (dos) orillas (pp. 205-223). Buenos Aires: Del Estante Editorial.

Castoriadis, C. (2002). Figuras de lo pensable (Las encrucijadas del laberinto VI). México: Fondo de Cultura Económica.

Clandinin, J., \& Connelly, M. (2000). Narrative Inquiry: Experience and story in qualitative research. San Francisco, CA: Jossey-Bass.

Contreras, J. (1997). La profesionalización del Profesorado. España: Morata.

Davini, M.C. (1989). Formación de profesores y transición democrática: continuidad y transformaciones. Tesis de doctorado. Pontificia Universidad Católica de Río de Janeiro, Brasil.

De Certeau, M. (2000). La invención de lo cotidiano. I. Artes de hacer. México: ITESO / Universidad Iberoamericana.
Del Río, L.N. (2009). Trayectorias educativas de estudiantes y egresados sordos del nivel medio y superior. Hologramática. Revista Académica de la Facultad de Ciencias Sociales de la UNLZ, 1(1 1), 37-60.

Denzin, N.K. (1986). Interpretative interactionism and the use of life stories. Revista Internacional de Sociología, 44(3), 321-337. Denzin, N.K., \& Lincoln, Y.S. (Eds.). (1989). Handbook of qualitative research. Thousand Oaks, CA: Sage.

Díaz-Barriga, F., Batres, L., Carrizales, L., Mejía, J., \& Calderón, J. (s.f.). Exposición infantil al plomo en la zona vecina a una fundición de cobre. Laboratorio de toxicología ambiental. Facultad de Medicina. Universidad Autónoma de San Luis Potosí. Recuperado de http://www.bvsde.paho.org/bvsacd/ eco/039944/039944-07.pdf

Echeita, G. (2009). Los procesos de inclusión educativa desde la Declaración de Salamanca. Un balance doloroso y esperanzado. En C. Giné (Coord.), La educación inclusiva: de la exclusión a la plena participación de todo el alumnado (pp. 25-48). Barcelona: ICE-Horsori.

Etxeberría, X. (2000). Ética de la diferencia. España: Universidad de Deusto.

Filidoro, N. (2003). Nuevas formas de exclusión. En Educación Especial. Inclusión Educativa: nuevas formas de exclusión. Psicología y educación, ensayos y experiencias. Buenos Aires: Centro de Publicaciones Educativas y Material Didáctico. 
Foucault, M. (2006). Los anormales. México: FCE.

Franklin, B.M. (1996). Introducción: Lectura de los textos sobre discapacidad. En B. Franklin (Comp.), Interpretación de la discapacidad. Teoría e historia de la educación especial. España: Pomares-Corredor.

Freire, P. (1993). Política y Educación. Madrid: Siglo XXI.

Frye, D. (1996). Indians into Mexicans: history and identity in a Mexican town. Austin: University of Texas Press.

García, C. (2001). ¿ ¿En qué fallaron los pronósticos de Binet y Simón? En J.J. Bueno, T. Núñez, \& A. Iglesias (Coords.), Atención educativa a la diversidad en el nuevo milenio (pp. 23-44). La Coruña: Servicio de Publicaciones de la Universidad. Recuperado de https://core.ac.uk/ download/pdf/61908049.pdf

García, N. (2004). Diferentes, desiguales y desconectados. Mapas de la interculturalidad. Barcelona: Gedisa.

Geertz, C. (1996). Los usos de la diversidad. Barcelona: Paidós.

Goffman, E. (2003). Estigma. La identidad deteriorada. Argentina: Amorrortu.

Guglielmino, E. (2009). La integración escolar y la inclusión educativa en el cruce de fronteras. XVIII Jornadas Nacionales de RUEDES -Red Universitaria De Educación Especial- y RECCEE -Red De Estudiantes De Cátedras y Carreras De Educación Especial-, "Educación Especial. Derecho A La Diferencia" Santa Fe, Argentina.
Guglielmino, M.E., Valente, G.M., \& Mendes, A. (2003). Puesta en escena: la diferencia y la educación especial. Volver la mirada hacia uno mismo. En M.J. Amadeo et al., Educación Especial: Inclusión Educativa: nuevas formas de exclusión. Buenos Aires: Ediciones Novedades Educativas.

Haidar, J. (1998). Análisis del discurso. En J. Galindo (Coord.), Técnicas de Investigación. En Sociedad, cultura y comunicación (pp. 118-164). México: Pearson.

Instituto Nacional de Estadística y Geografía (INEGI). (2000). XII Censo de Población y Vivienda 2000.

Instituto Nacional de Estadística y Geografía (INEGI). (2015a). Anuario estadístico y geográfico de San Luis Potosí 2015. Recuperado de http://www.datatur.sectur. gob.mx/ITxEF_Docs/SLP_ANUARIO_ PDF15.pdf

Instituto Nacional de Estadística y Geografía (INEGI). (2015b). México en cifras. San Luis Potosí. Recuperado de http://www.beta.inegi.org.mx/app/ areasgeograficas/?ag=24\#

Instituto Nacional de Estadística y Geografía (INEGI). (2015c). Panorama sociodemográfico en San Luis Potosí. Encuesta intercensal 2015. Recuperado de http://internet.contenidos.inegi. org. $\mathrm{mx} /$ contenidos/productos//prod_ serv/contenidos/espanol/bvinegi/ productos/nueva_estruc/inter_censal/ panorama/702825082345.pdf 
Instituto Nacional de Estadística y Geografía (INEGI). (2016). Anuario estadístico y geográfico de San Luis Potosí 2016. México: INEGI. Recuperado de http://www.datatur. sectur.gob.mx/ITxEF_Docs/SLP_ANUARIO_ PDF16.pdf

Jacobo, Z. (2012). Las paradojas de la integración/exclusión en las prácticas educativas. Efectos de discriminación o lazo social. Buenos Aires: Noveduc.

Jerez, C. (1989). Actualización crítica del discurso sociológico vigente en Educación Especial. Revista Cultura Pedagógica, (2), 46-54.

Lacan, J. [1949]. (1980). El estadio del espejo como formador de la función del yo ("je") tal como se nos revela en la experiencia analítica. México: Siglo Veintiuno Editores.

López, C.A, Méndez, J.M., \& Mendoza, F. (2014). Construyendo políticas de equidad en los procesos de admisión. El caso de la Universidad Autónoma de San Luis Potosí. En J. Gairín, G. Palmeros, \& A. Barrales (Coords.), Universidad y colectivos vulnerables (pp. 676- 689). Ciudad de México: Accedes.

López, M., \& Guerrero, L. (Comps.). (1993). Lecturas sobre Integración Escolar y Social. España: Paidós.

McLaren, P. (1984). La vida en las escuelas. Una introducción a la pedagogía crítica en los fundamentos de la educación. México: Siglo XXI.
Mitchell, D. (Ed.). (2004). Special educational needs and inclusive education. Major themes in education. Volume I. Systems and contexts. London: Routledge Falmer.

Narváez, E. (2006). Una mirada a la escuela nueva. Educere, 10(35), 629-636. Recuperado de https://www.redalyc.org/ articulo.oa? id $=35603508$

Organización de las Naciones Unidas para la Educación, la Ciencia y la Cultura (UNESCO). (2005). Orientaciones para la Inclusión: Asegurar el Acceso a la Educación para Todos. París: UNESCO.

Pacheco, J.E. (2005). Jardín de Niños No. 19. En La fábula del tiempo. Antología. México: Ediciones Era.

Pedraza, J. (1994). Historia de la ciudad de San Luis Potosí Compendio. México: Centro de Investigación histórica de San Luis Potosí.

Peña, F. (1894). Estudio Histórico sobre San Luis Potosí. México: Imprenta editorial de "El Estandarte".

Pérez de Cuéllar, J. (1997). Nuestra Diversidad Creativa: Informe de la Comisión Mundial de Cultura y Desarrollo. México: UNESCO.

Pérez de Lara, N. (1998). La capacidad de ser sujeto. Más allá de las técnicas de educación especial. España: Alertes.

Pujadas, J. (1992). Elaboración de una historia de vida. En El método biográfico: El uso de las historias de vida en las ciencias sociales. España: Centro de Investigaciones sociológicas. 
Ramos, L.A., Méndez, J.M., \& Mendoza, F. (2009). Trayectorias escolares de alumnos excepcionales en la Universidad Autónoma de San Luis Potosí. Educomunidad [Blog] Recuperado de http://educomunidad. blogspot.com/2007/02/trayectoriasescolares-de-alumnos.html

Redondo, P. (2004) Escuelas y pobreza. Entre el desasosiego y la obstinación. Buenos Aires: Paidós.

Revueltas, J. (1943). El luto humano. México: Editorial México.

Ribeiro, L. (1992). La educación de los educadores. México: El Caballito.

Ricoeur, P. (1995). Tiempo y Narración III. El tiempo narrado. México: Siglo XXI.

Romano, A. (2006). Lo que no tiene nombre: la pobreza en la educación. En P. Martinis, \& P. Redondo (Comps.), lgualdad y educación. Escrituras entre (dos) orillas (pp. 141-161). Buenos Aires: Del Estante Editorial.

Santos, L. (2006). Una historia de ausencias, Las políticas educativas del estado uruguayo hacia el medio rural en el decenio 19942004. En P. Martinis, \& P. Redondo (Comps.), Igualdad y educación. Escrituras entre (dos) orillas (pp. 81-101). Buenos Aires: Del Estante Editorial.

Secretaría General de Gobierno. (2013). H. Ayuntamiento de Mexquitic de Carmona. Plan Municipal de Desarrollo 2012-2015. Periódico oficial del Estado Libre y Soberano deSan LuisPotosí. Recuperadodehttp://www. cefimslp.gob.mx/V2/images/ArchivosPDF/ PLANESMUNICIPALES/02 1-2013-EE-PMD.pdf
Skliar, C. (2008). ¿̇Incluir las diferencias? Sobre un problema mal planteado y una realidad insoportable. Orientación y Sociedad, (8), 1-17. Recuperado de http://www.scielo. org.ar/pdf/orisoc/v8/v8a02.pdf

Skrtic, T.M. (1996). La crisis en el conocimiento de la educación especial: Una perspectiva sobre la perspectiva en Interpretación de la discapacidad. Teoríaehistoriadelaeducación especial. Barcelona: Pomares-Corredor. Torres, N.R., Díaz Barriga, M.F., Nieto, C.L., Carrizales, Y.L., Coronado, S.C., ... \& Cubillas, T.A. (s.f.). Diseño y aplicación de un programa de comunicación de riesgos para la salud ambiental en un sitio contaminado con plomo y arsénico. Documento. Facultad de Ciencias Químicas/CIEP, Universidad Autónoma de San Luis Potosí, México. Recuperado de https://www.uam.mx/cdi/ pdf/iii_chw/cubillastejeda_mx.pdf

Turrubiartes, L., Grimaldo, V.A., \& Pecina, M.A. (2001). Mexquitic de Carmona, S.L.P. Recuperado de http://red.ilce. edu.mx/20aniversario/componentes/ redescolar/publicaciones/publi_prodigios/ mexquitic/mexquitic.htm

Villa, N. (2009). Del "ocultamiento" a la visibilidad": Avances en los derechos de las personas con diversidad funcional durante un siglo (1907-2008). En M. Reyes Berruezo, \& S. Conejero (Coords.), El largo camino hacia la educación inclusiva. La educación especial y social del siglo XIX a nuestros días (pp. 209-219). España: Universidad Pública de Navarra. 
Qartuppi, S. de R.L. de C.V. está inscrita de forma definitiva en el Registro Nacional de Instituciones y Empresas Científicas y Tecnológicas (RENIECYT) con el número 1600052.

Qartuppi, S. de R.L. de C.V. es miembro activo de la Cámara Nacional de la Industria Editorial Mexicana (CANIEM) con número de registro 3751 .

\section{Narrativas e historias del medio rural \\ Procesos de inclusión y formación docente}

ISBN 978-607-98270-6-9

DOI 10.29410/QTP.19.03

Esta obra se terminó de producir en febrero de 2019.

Su edición y diseño estuvieron a cargo de:

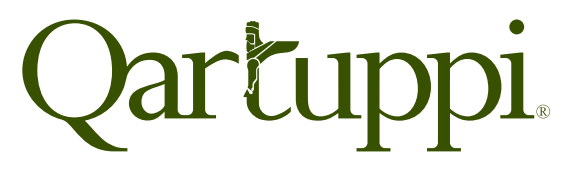

Qartuppi, S. de R.L. de C.V.

http://www.qartuppi.com 
Esta obra ofrece una realidad de México en torno al tema de la inclusión educativa, partiendo de un estudio realizado a nivel de educación básica en un contexto rural. Dicho estudio aborda los enfoques teóricos que subyacen, así como las narrativas y experiencias que se recuperan de los sujetos involucrados. Una de sus principales aportaciones es la necesidad de transformar los modelos de formación docente, que están divididos en sistemas paralelos de educación regular y educación especial, hacia una formación común basada en las diferencias como una característica afín a todos los individuos.

\section{Qartuppi.}

ISBN 978-607-98270-6-9
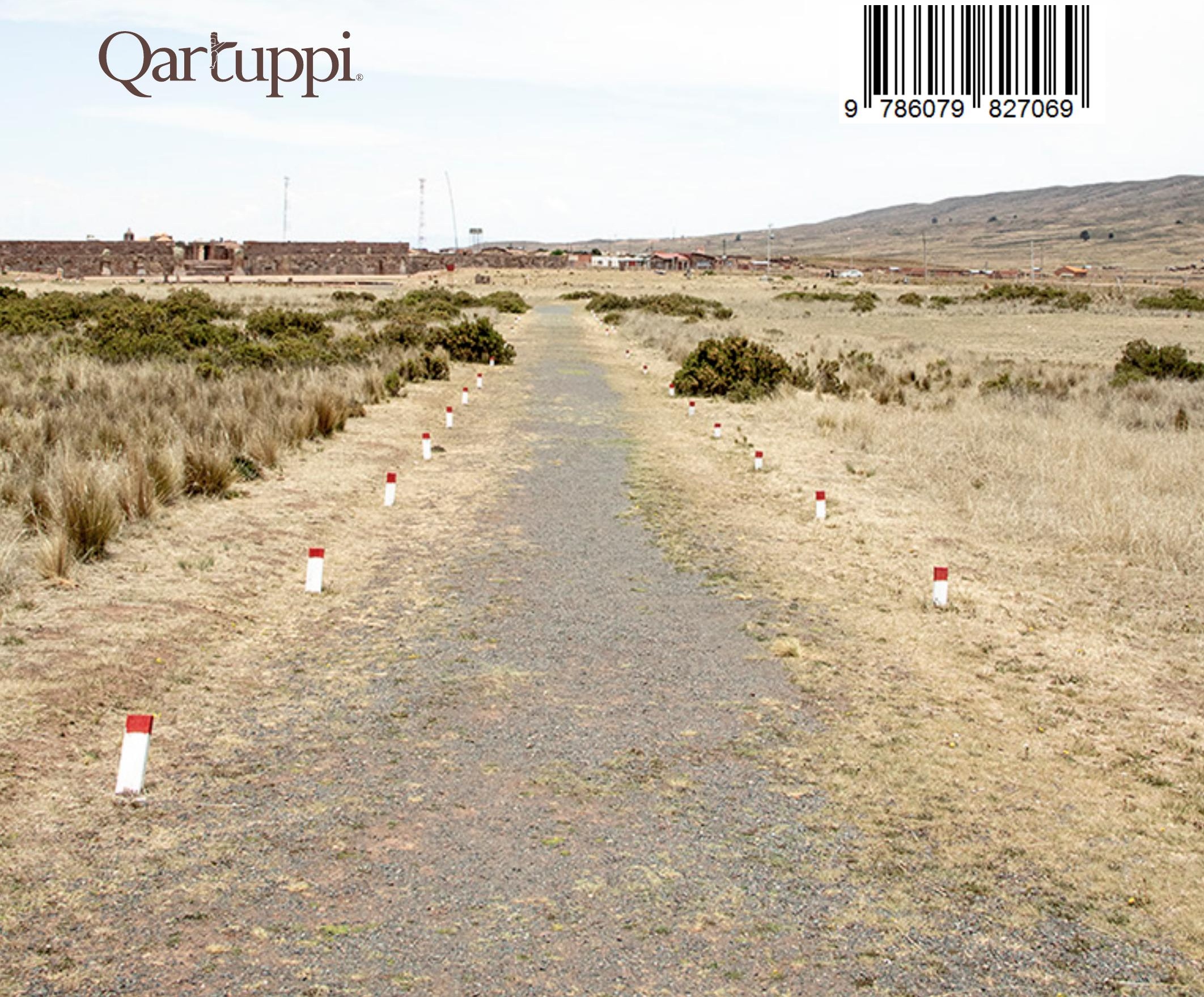